IONAL CENTER FOR
EDUCATION STATISTICS

U.S. Department of Education NCES 2007-162
The Path Through

Graduate School:

A Longitudinal

Examination 10 Years

After Bachelor's Degree

\section{Postsecondary Education}

Descriptive Analysis Report
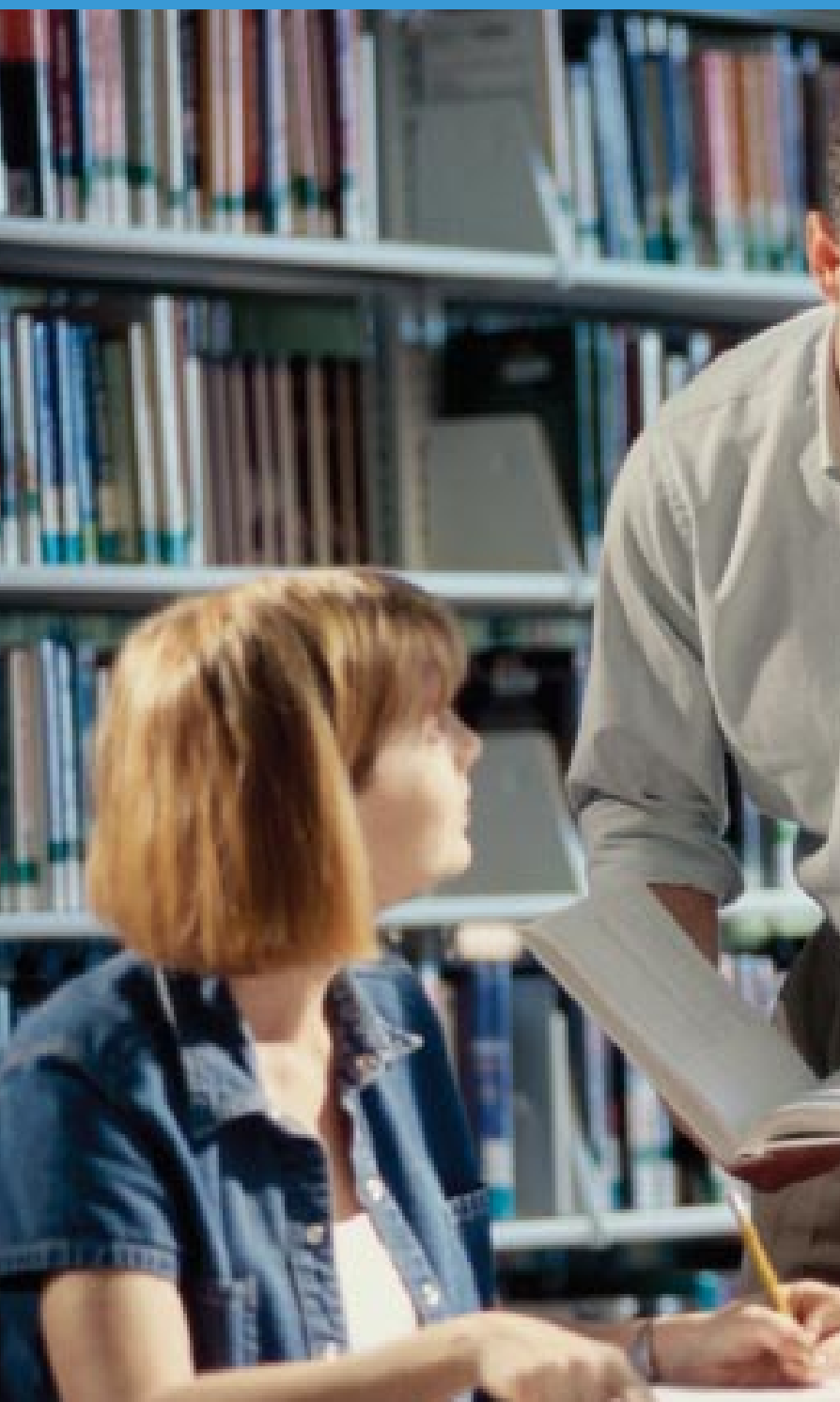


\section{THIS PAGE INTENTIONALLY LEFT BLANK}




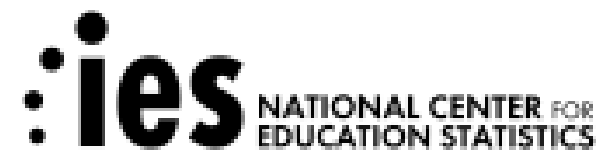

Institute of Edycotion $\$ c i e n c e$ I

PEDAR

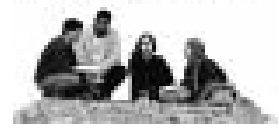

U.S. Department of Education Institute of Education Sciences NCES 2007-162

\section{The Path Through Graduate School: A Longitudinal Examination 10 Years After Bachelor's Degree}

\author{
Postsecondary Education \\ Descriptive Analysis Report
}

February 2007

Stephanie C. Nevill

Xianglei Chen

MPR Associates, Inc.

C. Dennis Carroll

Project Officer

National Center for

Education Statistics 


\section{U.S. Department of Education}

Margaret Spellings

Secretary

\section{Institute of Education Sciences}

Grover J. Whitehurst

Director

\section{National Center for Education Statistics}

Mark Schneider

Commissioner

The National Center for Education Statistics (NCES) is the primary federal entity for collecting, analyzing, and reporting data related to education in the United States and other nations. It fulfills a congressional mandate to collect, collate, analyze, and report full and complete statistics on the condition of education in the United States; conduct and publish reports and specialized analyses of the meaning and significance of such statistics; assist state and local education agencies in improving their statistical systems; and review and report on education activities in foreign countries.

NCES activities are designed to address high-priority education data needs; provide consistent, reliable, complete, and accurate indicators of education status and trends; and report timely, useful, and highquality data to the U.S. Department of Education, the Congress, the states, other education policymakers, practitioners, data users, and the general public. Unless specifically noted, all information contained herein is in the public domain.

We strive to make our products available in a variety of formats and in language that is appropriate to a variety of audiences. You, as our customer, are the best judge of our success in communicating information effectively. If you have any comments or suggestions about this or any other NCES product or report, we would like to hear from you. Please direct your comments to

National Center for Education Statistics

Institute of Education Sciences

U.S. Department of Education

$1990 \mathrm{~K}$ Street NW

Washington, DC 20006-5651

February 2007

The NCES World Wide Web Home Page address is http://nces.ed.gov.

The NCES World Wide Web Electronic Catalog is http://nces.ed.gov/pubsearch.

\section{Suggested Citation}

Nevill, S.C., and Chen, X. (2007). The Path Through Graduate School: A Longitudinal Examination 10 Years After Bachelor's Degree (NCES 2007-162). U.S. Department of Education. Washington, DC: National Center for Education Statistics.

\section{For ordering information on this report, write to}

U.S. Department of Education

ED Pubs

P.O. Box 1398

Jessup, MD 20794-1398

or call toll free 1-877-4ED-Pubs or order online at http://www.edpubs.org.

\section{Content Contact}

Aurora D'Amico

(202) 502-7334

aurora.d'amico@ed.gov 


\section{Executive Summary}

The benefits of graduate education are wide ranging. Individuals gain notable financial returns as well as personal and intellectual benefits. For society, well-educated and highly trained professionals contribute to economic and technological development (McMahon 1998). It is important, therefore, to understand the potential barriers that prevent access to and persistence in graduate education.

This report addresses several important questions about graduate education: Who enrolls in graduate school? What degrees do they pursue? What are their completion rates? Which factors are related to students' enrollment in and completion of graduate education?

The report uses data from the 1992-93 Baccalaureate and Beyond Study (B\&B:93/03), a longitudinal study of students who earned a bachelor's degree during the 1992-93 academic year. Base-year information on this cohort was collected as part of the 1992-93 National Postsecondary Student Aid Study (NPSAS:93). Graduates were interviewed again in 1994, 1997, and 2003. The estimates in this report are based on results of surveys with approximately 9,000 bachelor's degree recipients, representing about 1.2 million bachelor's degree completers from 1992 to 1993. This report focuses on 1992-93 bachelor's degree recipients' persistence in and completion of graduate education within 10 years of earning a bachelor's degree. All comparisons made in the text were tested using Student's $t$ statistic. All differences cited were statistically significant at the $p \leq .05$ level. The major findings are summarized below.

\section{Graduate Enrollment}

About 40 percent of 1992-93 bachelor's degree recipients had enrolled in a graduate degree program by 2003 (figure A, table 1). For 31 percent of graduates, their highest level of graduate enrollment by 2003 was a master's degree program; for 5 percent, it was a firstprofessional degree program; and for 4 percent, it was a doctoral degree program.

To get a more complete picture of the graduate enrollment experiences of 1992-93 bachelor's degree recipients, this analysis grouped students who enrolled in more than one program separately from those who enrolled in a single program. About 30 percent of all bachelor's degree recipients enrolled in a single graduate or firstprofessional degree program, and 10 percent of graduates enrolled in more than one program. Specifically, 5 percent enrolled in more than one master's degree program; 2 percent enrolled in a master's and doctoral degree program; and 3 percent enrolled in a first-professional degree program and another graduate degree program (figure $\mathrm{B}$, table 2). ${ }^{1}$

\footnotetext{
${ }^{1}$ Multiple programs were determined over the course of the 10 -year period. For example, a student may have initially enrolled in one master's program early after completing a bachelor's degree, left the program, and subsequently returned to enroll in another master's program. Enrollment in a master's and doctoral or a first-professional and other program should not suggest that the student first enrolled in a master's degree program and then went on to pursue a doctoral or first-professional degree program. For example, a student may have enrolled in a doctoral degree program, but instead decided to finish with a master's degree. The opposite could be true as well: a student may have enrolled in a master's degree program and later decided to pursue a doctoral degree. The sequence of enrollment in multiple programs is not discussed in this report.
} 
Figure A. Percentage distribution of 1992-93 bachelor's degree recipients' highest graduate enrollment

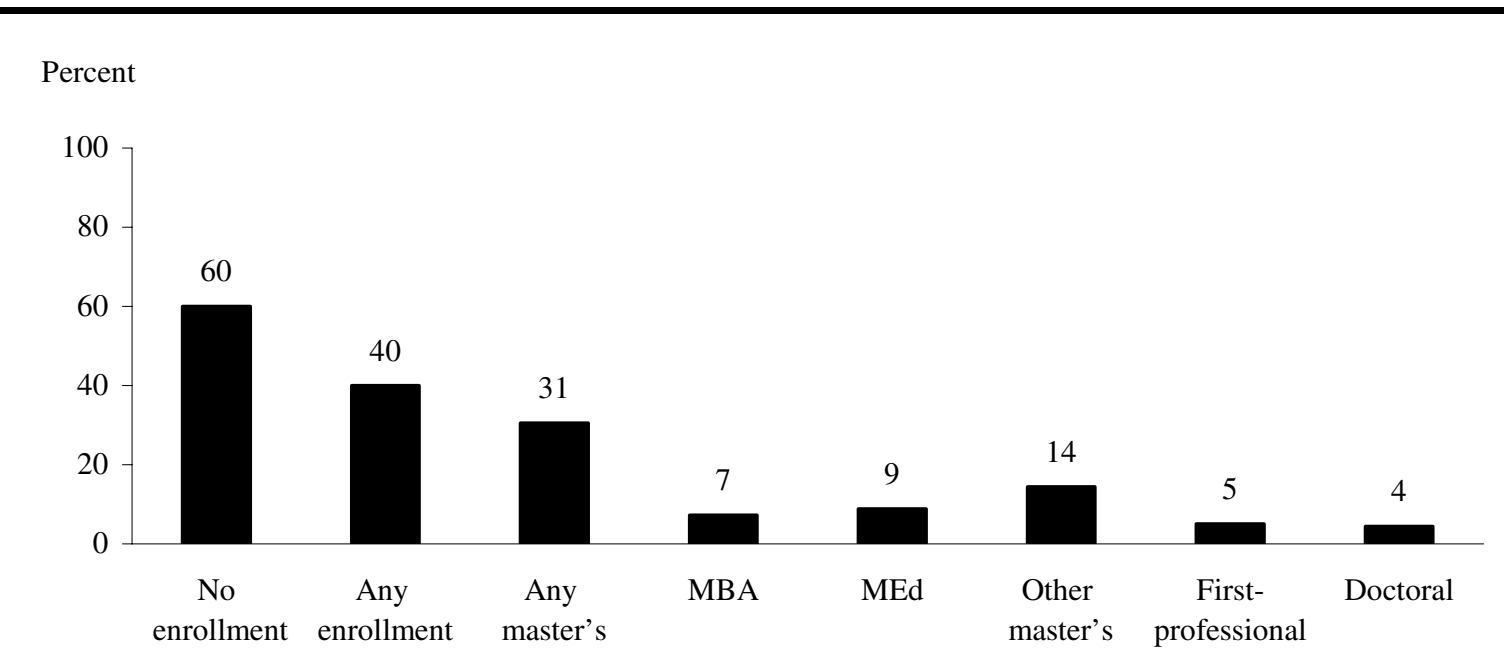

Highest graduate enrollment

NOTE: Estimates include students from the 50 states, DC, and Puerto Rico. Detail may not sum to totals because of rounding. Standard error tables are available at http://nces.ed.gov/das/library/reports.asp.

SOURCE: U.S. Department of Education, National Center for Education Statistics, 1993/03 Baccalaureate and Beyond Longitudinal Study (B\&B:93/03).

Graduate enrollment was related to a number of demographic and academic characteristics, such as students' race/ethnicity, age, undergraduate major and grade point average (GPA), and parents' education. For example, Asian/Pacific Islander students were more likely to enroll in a first-professional degree program than students in other racial/ethnic groups (14 vs. 4 to 5 percent, table A). Younger students were more likely than older students (48 vs. 27 to 36 percent) to enroll in a graduate degree program. The same was true for single students; they were more likely than married students ( 43 vs. 32 percent) to enroll in a graduate degree program (table 3 ). Students who had majored in biological sciences as undergraduates were more likely to enroll in a graduate degree program than students who had majored in other subjects (67 vs. 25 to 55 percent, figure $\mathrm{C}$ ). Academic characteristics that students displayed as undergraduates were also important. Higher achieving students (with GPAs of 3.5 or above) were more likely to enroll in a graduate program than lower achieving students (52 vs. 23 to 43 percent, table A).

\section{Time to Enrollment}

On average, most 1992-93 bachelor's degree recipients waited between 2 and 3 years to enroll for the first time in a graduate degree program (table 6). Students entering MBA programs typically waited longer (about 4 years) than students entering any other type of degree program, and doctoral degree students typically waited the least amount of time (under 2 years) (table B). Students who enrolled in multiple programs (both doctoral and master's degree programs or first-professional and another graduate degree program) entered a graduate program within 1 year of completing a bachelor's degree, on average. Students age 22 or younger 
Figure B. Percentage of 1992-93 bachelor's degree recipients who had enrolled in single and multiple graduate degree programs by 2003 , by type of graduate degree program

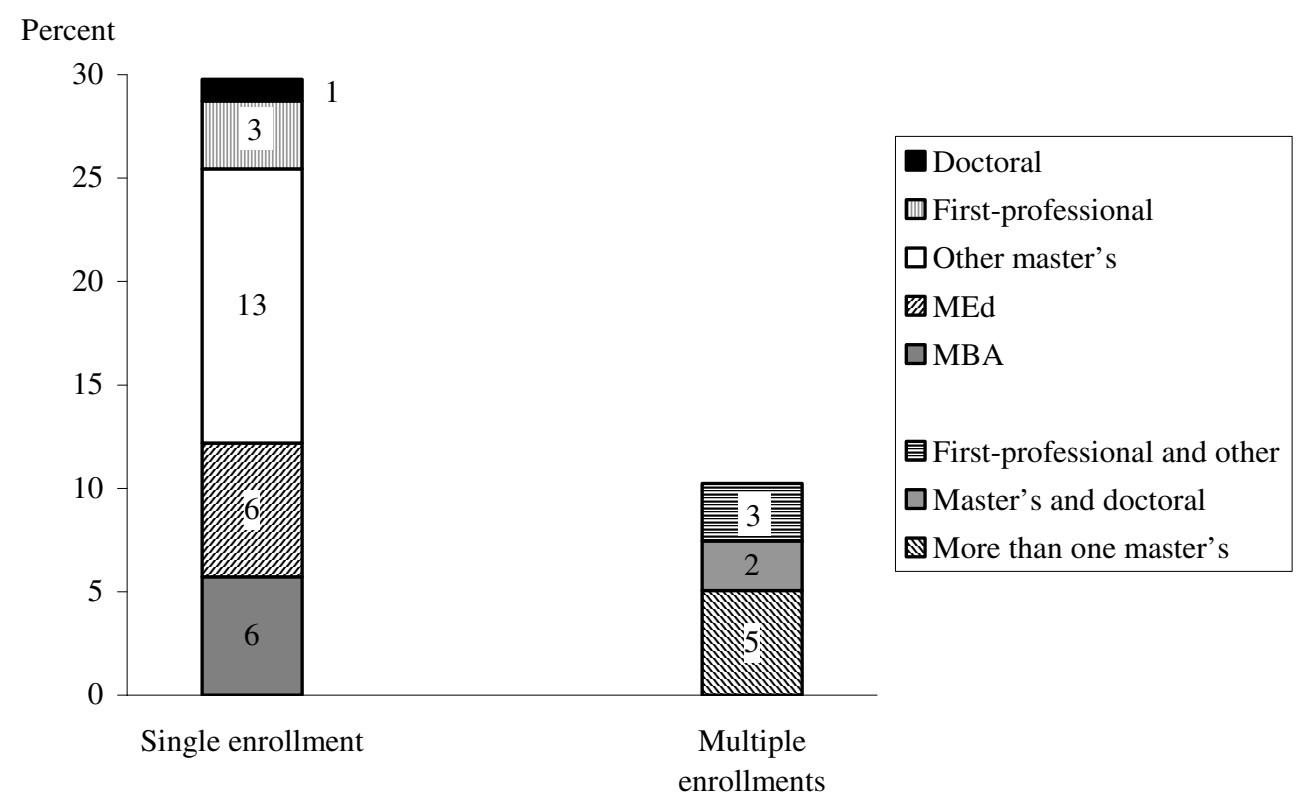

NOTE: Estimates include students from the 50 states, DC, and Puerto Rico. Standard error tables are available at http://nces.ed.gov/das/library/reports.asp.

SOURCE: U.S. Department of Education, National Center for Education Statistics, 1993/03 Baccalaureate and Beyond Longitudinal Study (B\&B:93/03).

and those age 30 or older at the time they were awarded bachelor's degrees waited less time to begin a graduate program than students in their mid-20s (table 6). Other factors such as students' race/ethnicity, undergraduate major and GPA, and marital and parental status and parents' education were related to the amount of time it took to enter graduate school (tables 6 and 7).

\section{Characteristics of Enrollment}

About one-half of 1992-93 bachelor's degree recipients who enrolled in a graduate degree program attended exclusively full time (table 11). When students who had enrolled in a graduate degree program were asked whether they took a semester or term off during their studies other than for summer sessions, about one-half indicated that they had done so. Rates of full-time enrollment were higher among men than women (54 vs. 46 percent), and among students whose highest graduate enrollment was a first-professional or doctoral degree ( 84 and 73 percent vs. 29 to 50 percent). Students whose parents had graduate degrees were more likely to enroll full time than students whose parents had less education (58 vs. 40 to 51 percent), and students who had higher GPAs (3.5 or above) as undergraduates were more likely to enroll full time than students with GPAs lower than 3.0 (55 vs. 41 to 44 percent). 
Table A. Percentage distribution of 1992-93 bachelor's degree recipients' highest graduate enrollment, by race/ethnicity and age: 2003

\begin{tabular}{|c|c|c|c|c|c|c|c|}
\hline \multirow[b]{2}{*}{$\begin{array}{l}\text { Student and institution } \\
\text { characteristics }\end{array}$} & \multirow[b]{2}{*}{$\begin{array}{r}\text { No } \\
\text { enroll- } \\
\text { ment }\end{array}$} & \multicolumn{6}{|c|}{ Highest graduate enrollment } \\
\hline & & $\begin{array}{r}\text { Total } \\
\text { any } \\
\text { enroll- } \\
\text { ment }\end{array}$ & MBA & MEd & $\begin{array}{r}\text { Other } \\
\text { master's }\end{array}$ & $\begin{array}{l}\text { First- } \\
\text { profes- } \\
\text { sional }\end{array}$ & Doctoral \\
\hline Total & 60.0 & 40.0 & 7.3 & 8.8 & 14.4 & 5.0 & 4.5 \\
\hline \multicolumn{8}{|l|}{ Race/ethnicity $^{1}$} \\
\hline White & 60.8 & 39.2 & 7.0 & 9.2 & 14.2 & 4.5 & 4.3 \\
\hline Black & 54.6 & 45.4 & 8.3 & 7.5 & 19.1 & 5.3 & 5.2 \\
\hline Hispanic & 56.3 & 43.7 & 9.4 & 9.7 & 13.9 & 4.7 & 6.1 \\
\hline Asian/Pacific Islander & 58.5 & 41.5 & 8.3 & 3.3 & 12.7 & 13.6 & 3.7 \\
\hline \multicolumn{8}{|c|}{ Age at bachelor's degree completion } \\
\hline 22 or younger & 51.8 & 48.3 & 7.8 & 9.4 & 16.9 & 7.7 & 6.5 \\
\hline $23-24$ & 67.9 & 32.1 & 5.8 & 8.2 & 11.2 & 3.3 & 3.6 \\
\hline $25-29$ & 72.8 & 27.2 & 6.5 & 5.8 & 11.5 & 2.0 & 1.6 \\
\hline 30 or older & 63.8 & 36.2 & 8.2 & 9.9 & 14.6 & 1.9 & 1.6 \\
\hline \multicolumn{8}{|l|}{ Bachelor's degree GPA } \\
\hline Under 2.5 & 76.5 & 23.5 & 4.4 & 6.3 & 9.9 & 1.6 & 1.3 \\
\hline $2.5-2.99$ & 64.4 & 35.6 & 7.3 & 8.3 & 13.8 & 3.3 & 3.0 \\
\hline $3.0-3.49$ & 56.6 & 43.4 & 7.6 & 9.7 & 15.0 & 6.2 & 4.9 \\
\hline 3.5 or above & 47.8 & 52.2 & 9.0 & 10.1 & 17.7 & 7.5 & 7.8 \\
\hline
\end{tabular}

${ }^{1}$ Black includes African American, Pacific Islander includes Native Hawaiian, and Hispanic includes Latino. Included in the totals but not shown separately are data for American Indian/Alaska Native respondents and those who identified themselves with another race not shown. Race categories exclude Hispanic origin unless specified.

NOTE: Estimates include students from the 50 states, DC, and Puerto Rico. Detail may not sum to totals because of rounding. Standard error tables are available at http://nces.ed.gov/das/library/reports.asp.

SOURCE: U.S. Department of Education, National Center for Education Statistics, 1993/03 Baccalaureate and Beyond Longitudinal Study (B\&B:93/03).

\section{Persistence and Attainment}

Among 1992-93 bachelor's degree recipients who had enrolled in a graduate degree program between 1993 and 2003, some 62 percent had earned at least one graduate degree by 2003 (table C). Looking at the highest degree earned, 47 percent had earned a master's degree, 10 percent a first-professional degree, and 5 percent a doctoral degree. About 15 percent were still enrolled in a graduate degree program in 2003, and 23 percent were no longer enrolled and had not obtained a graduate degree. Degree attainment was related to the type of graduate degree program in which students had enrolled. First-professional students were more likely than master's or doctoral students to have obtained a degree: 71 percent of graduate students who enrolled in a firstprofessional degree program had earned a firstprofessional degree by 2003, compared with 60 percent of master's students and 43 percent of doctoral students who earned degrees in their respective programs. 
Figure C. Percentage of 1992-93 bachelor's degree recipients who had enrolled in a graduate degree program by 2003 , by undergraduate major and graduate degree program

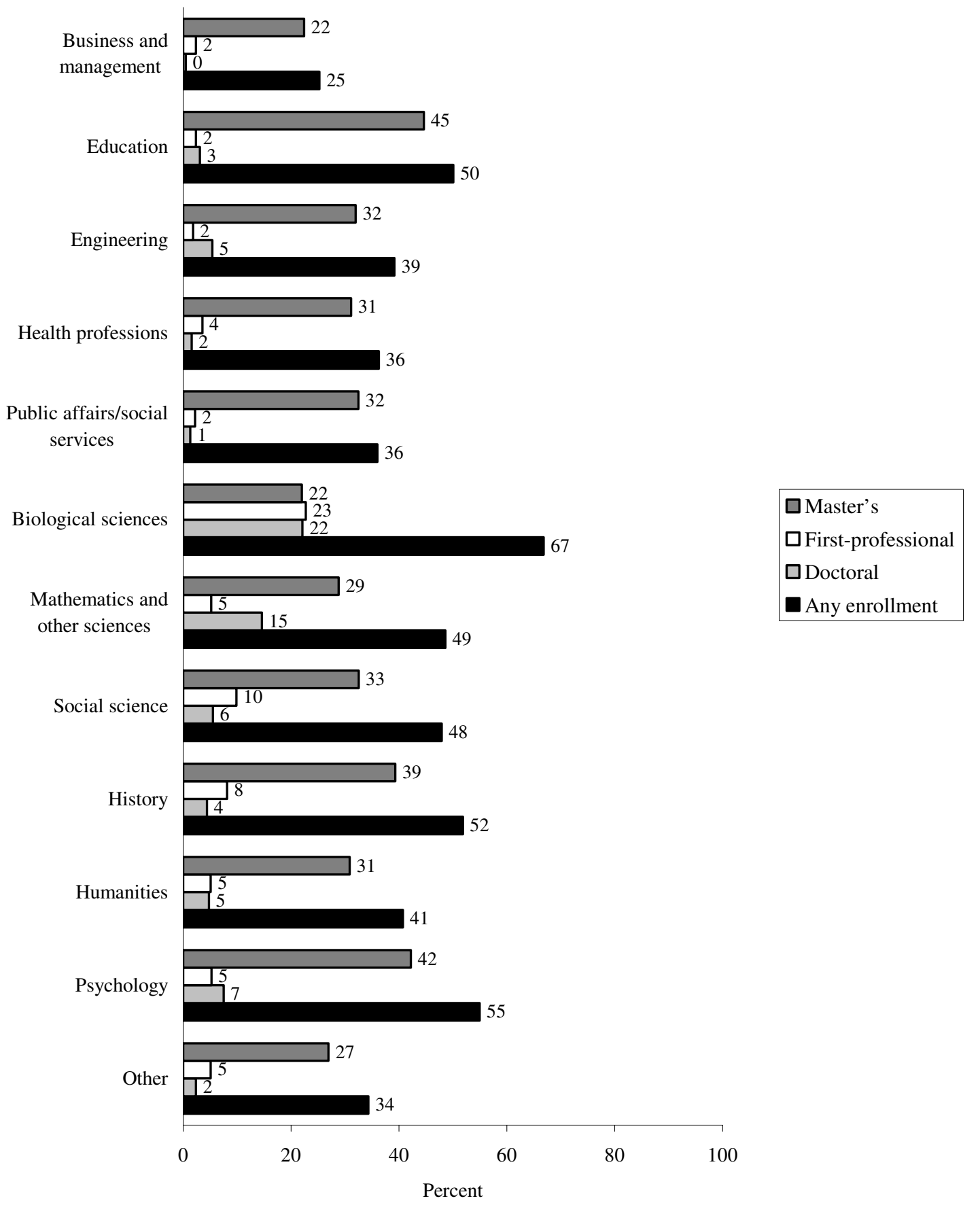

NOTE: Estimates include students from the 50 states, DC, and Puerto Rico. Standard error tables are available at http://nces.ed.gov/das/library/reports.asp.

SOURCE: U.S. Department of Education, National Center for Education Statistics, 1993/03 Baccalaureate and Beyond Longitudinal Study (B\&B:93/03). 
Table B. Among 1992-93 bachelor's degree recipients who had enrolled in a graduate degree program by 2003, percentage distribution of time and average time between bachelor's degree receipt and first graduate enrollment, by type of graduate enrollment and degree program

\begin{tabular}{|c|c|c|c|c|c|}
\hline \multirow[b]{2}{*}{ Graduate degree program } & \multicolumn{4}{|c|}{ Percentage distribution } & \multirow{2}{*}{$\begin{array}{r}\text { Average } \\
\text { number of } \\
\text { years }\end{array}$} \\
\hline & $\begin{array}{l}1 \text { year } \\
\text { or less }\end{array}$ & $\begin{array}{r}\text { More than } \\
1 \text { to } 3 \text { years } \\
\end{array}$ & $\begin{array}{r}\text { More than } \\
3 \text { to } 5 \text { years } \\
\end{array}$ & $\begin{array}{r}\text { More than } \\
5 \text { years } \\
\end{array}$ & \\
\hline All graduate enrollment & 35.9 & 28.3 & 16.2 & 19.5 & 2.7 \\
\hline \multicolumn{6}{|l|}{ Single enrollment } \\
\hline MBA & 16.1 & 21.3 & 22.8 & 39.8 & 4.2 \\
\hline $\begin{array}{l}\text { MEd or post-master's certifi } \\
\text { in education }\end{array}$ & 23.9 & 28.9 & 21.1 & 26.2 & 3.4 \\
\hline Other master's & 30.6 & 30.1 & 16.7 & 22.5 & 2.9 \\
\hline First-professional & 44.3 & 27.5 & 13.2 & 15.0 & 2.2 \\
\hline Doctoral & 54.0 & 22.1 & 11.8 & 12.1 & 1.8 \\
\hline \multicolumn{6}{|l|}{ Multiple enrollment } \\
\hline More than one master's & 48.7 & 34.2 & 15.2 & 2.0 & 1.5 \\
\hline Master's and doctoral & 67.9 & 21.4 & 7.2 & 3.5 & 1.1 \\
\hline First-professional and other & 63.3 & 32.0 & 3.8 & 1.0 & 0.9 \\
\hline
\end{tabular}

NOTE: Estimates include students from the 50 states, DC, and Puerto Rico. Detail may not sum to totals because of rounding. Standard error tables are available at http://nces.ed.gov/das/library/reports.asp.

SOURCE: U.S. Department of Education, National Center for Education Statistics, 1993/03 Baccalaureate and Beyond

Longitudinal Study (B\&B:93/03).

Table C. Among 1992-93 bachelor's degree recipients who had enrolled in a graduate degree program by 2003, percentage distribution of attainment and enrollment status in 2003, by highest graduate enrollment

\begin{tabular}{|c|c|c|c|c|c|c|c|c|c|}
\hline \multirow[b]{2}{*}{$\begin{array}{l}\text { Highest graduate } \\
\text { enrollment }\end{array}$} & \multicolumn{4}{|c|}{ Attained } & \multicolumn{4}{|c|}{ Enrolled } & \multirow{2}{*}{$\begin{array}{r}\mathrm{No} \\
\text { degree } \\
\text { no longer } \\
\text { enrolled }\end{array}$} \\
\hline & Total & Master's ${ }^{1}$ & $\begin{array}{r}\text { First- } \\
\text { profes- } \\
\text { sional }\end{array}$ & Doctoral & Total & Master's & $\begin{array}{l}\text { First- } \\
\text { profes- } \\
\text { sional }\end{array}$ & Doctoral & \\
\hline Total & 61.9 & 47.1 & 10.0 & 4.8 & 14.7 & 10.5 & 1.3 & 2.9 & 23.4 \\
\hline Master's & 60.1 & 60.1 & $\dagger$ & $\dagger$ & 13.4 & 13.4 & $\dagger$ & $\dagger$ & 26.6 \\
\hline First-professional ${ }^{2}$ & 74.8 & 3.4 & 71.4 & $\dagger$ & 10.7 & 1.6 & 9.0 & $\dagger$ & 14.5 \\
\hline Doctoral $^{2}$ & 60.2 & 9.3 & 7.5 & 43.4 & 28.4 & 0.9 & 1.7 & 25.9 & 11.4 \\
\hline
\end{tabular}

$\dagger$ Not applicable.

${ }^{1}$ Students who have attained a master's degree are identified as having a master's degree if no higher degree was attained and the student was not enrolled in a doctoral or first-professional degree program in 2003.

${ }^{2}$ Includes students who have earned a master's degree.

NOTE: Estimates include students from the 50 states, DC, and Puerto Rico. Detail may not sum to totals because of rounding. Standard error tables are available at http://nces.ed.gov/das/library/reports.asp.

SOURCE: U.S. Department of Education, National Center for Education Statistics, 1993/03 Baccalaureate and Beyond Longitudinal Study (B\&B:93/03). 
Rates of graduate persistence and degree attainment were related to a number of demographic characteristics, such as students' gender, race/ethnicity, and age and parents' education. Specifically, women were more likely than men to have earned a master's degree (49 vs. 44 percent), while men were more likely than women to have earned a first-professional (13 vs. 8 percent) or a doctoral degree (7 vs. 3 percent; table 14). The likelihood of earning a graduate degree was related to parents' highest education level as well, with the rate increasing from 53 percent among those whose parents had less than a high school education to 67 percent among those whose parents had a graduate degree.
There was a strong relationship between a student's family responsibilities and graduate persistence and attainment. Students who were single or had no children before graduate enrollment were more likely to have earned a graduate degree, particularly a first-professional or doctoral degree, while students who were already married or had children were more likely to be still enrolled (table 15). Parenthood seemed to have a stronger negative effect for women than for men. For example, among men, having a child before graduate enrollment was negatively related only to their likelihood of attaining a firstprofessional degree; while it does appear that men having no children were more likely to attain a graduate degree, no statistical difference was detected (figure D). Among women, having a

Figure D. Among 1992-93 bachelor's degree recipients who had enrolled in a graduate degree program by 2003 , percentage who had attained a graduate degree by 2003 , by gender and parental status 1 year before graduate enrollment

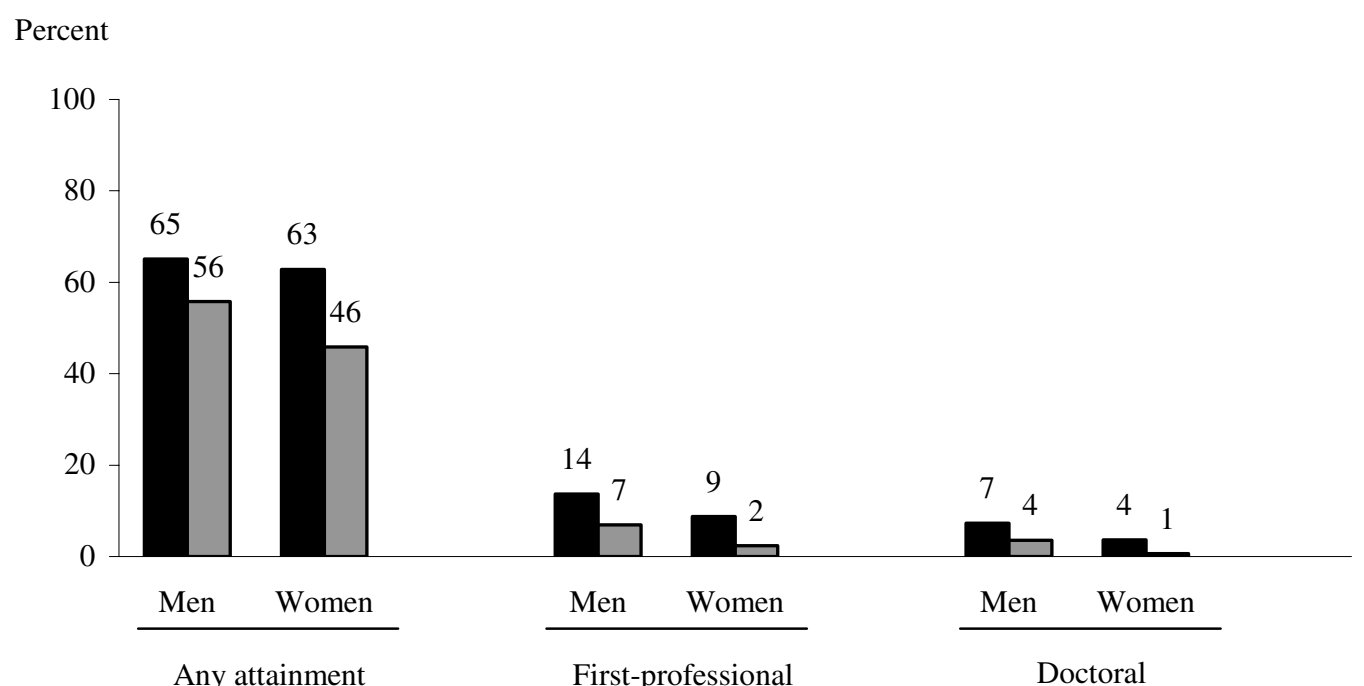

No children $\square$ One or more children

NOTE: Estimates include students from the 50 states, DC, and Puerto Rico. Standard error tables are available at http://nces.ed.gov/das/library/reports.asp.

SOURCE: U.S. Department of Education, National Center for Education Statistics, 1993/03 Baccalaureate and Beyond Longitudinal Study (B\&B:93/03). 
child was negatively related to overall graduate degree attainment, especially of a first-

professional and doctoral degree.

Graduates' degree attainment did not necessarily align with students' educational expectations at the time they completed a bachelor's degree in 1992-93. This pattern was especially evident among those with doctoral degree aspirations: 11 percent of graduate students who expected to earn a doctoral degree had done so by 2003 , while 41 percent had earned a terminal master's degree (table 16). About 46 percent of graduate students with firstprofessional degree expectations had earned a first-professional degree, and 57 percent of those with master's degree expectations had earned a master's degree.

\section{Time to Graduate Degree}

Among students who completed a graduate degree within the 10-year study period, master's degree students took an average of 3 years to complete a degree, first-professional students took about 4 years, and doctoral students took about 6 years (figure 2 and figure $\mathrm{E}$ ). The time it took students to complete a graduate degree was related to several student characteristics. For example, Hispanic students took longer than Asian/Pacific Islander, Black, and White students to finish a master's degree (table 18a). Among students who had completed a master's degree, younger students (age 22 or younger) took less time to complete a degree than older students (age 30 or older). Not surprisingly, master's and firstprofessional degree recipients who interrupted

Figure E. Among 1992-93 bachelor's degree recipients who had earned a graduate degree by 2003, average number of years between first graduate enrollment and attainment of highest graduate degree, by highest graduate degree earned

Number of years

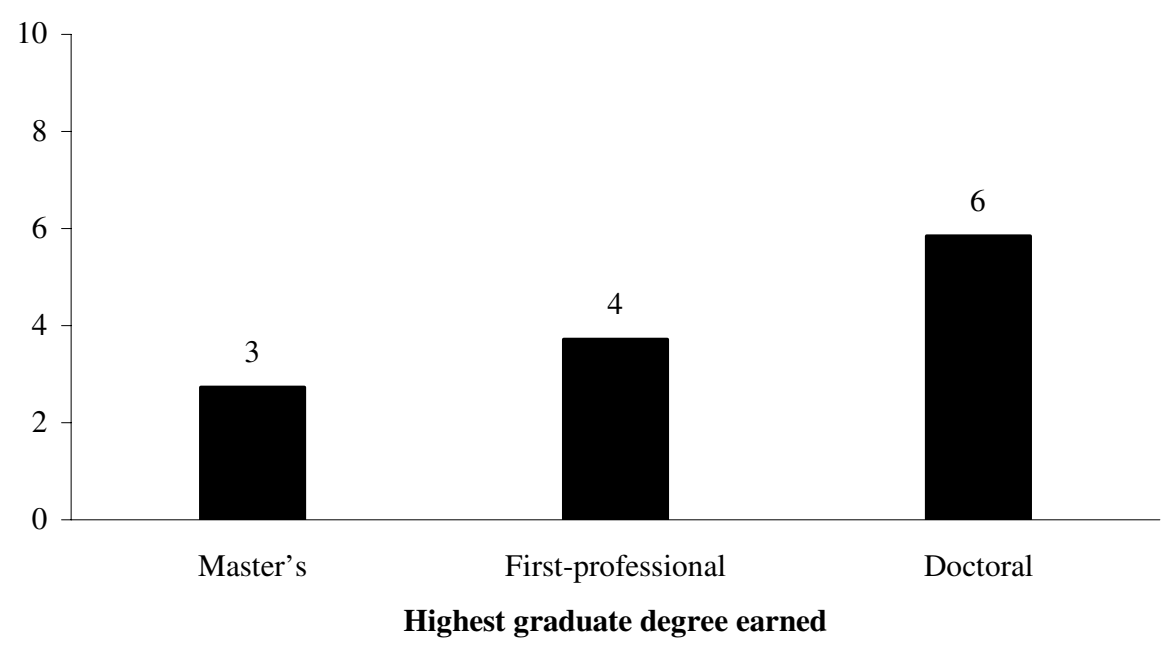

NOTE: Estimates include students from the 50 states, DC, and Puerto Rico. Standard error tables are available at http://nces.ed.gov/das/library/reports.asp.

SOURCE: U.S. Department of Education, National Center for Education Statistics, 1993/03 Baccalaureate and Beyond Longitudinal Study (B\&B:93/03). 
their enrollment took more time to complete a degree than those who did not take a break between degrees (tables 18c and 19c). Because so few students had earned a doctoral degree by 2003 (only 5 percent of all graduate students; see table 12), comparisons between many subgroups of doctoral degree recipients were not possible due to small sample sizes.

\section{Factors Related to Graduate Enrollment, Persistence, and Attainment}

Three multivariate commonality analyses were performed to gain a better understanding of how graduate enrollment, persistence, and attainment were related to various demographic and academic characteristics. ${ }^{2}$ The first analysis focuses on factors related to students' likelihood of enrolling in a graduate degree program after receiving a bachelor's degree. After controlling for other factors, several demographic and academic characteristics maintained a significant relationship with enrollment in graduate school. For example, enrollment rates among students age 22 or younger were higher than those among students ages 23-29 (table 21). Students with GPAs of 3.5 or above were more likely to enroll than those with lower GPAs.

The second analysis examines factors related to the likelihood of students in a graduate degree program completing a degree by 2003 . After controlling for all other variables, several

\footnotetext{
2 A commonality analysis is an approach in which a multiple linear regression is used to look at the relationship between an independent variable and an outcome variable while adjusting for the common variation among a group of independent variables. For more information, see Technical Notes and Methodology in appendix B.
}

enrollment characteristics, such as entry time, enrollment status, and graduate degree program, retained a significant relationship with graduate degree completion. Rates of completion were higher among students who entered graduate school immediately after earning a bachelor's degree than among those who waited more than 5 years to enroll (table 22). Students who enrolled full time, enrolled continuously, and enrolled in multiple programs were more likely than their counterparts to complete a graduate degree. In addition, students who had ever received grants, employer assistance, or a tuition waiver to help pay for their graduate education also had a higher completion rate than those who had never received any of these types of financial aid.

The third analysis broadens the definition of degree completion to include students who completed a graduate degree by 2003 or were still enrolled in a graduate program as of 2003. Enrollment characteristics and financial aid continued to play an important role in students' persistence: students who entered a graduate program immediately after earning a bachelor's degree, attended full time and did not take time off, enrolled in multiple programs, and had received grants, employer assistance, or a tuition waiver had higher persistence rates than their counterparts who waited more than 5 years to enroll, attended part time, took time off, enrolled in a single degree program, and had never received any grants, employer assistance, or a tuition waiver (table 22). 


\section{Foreword}

This report uses data collected from the 1993/03 Baccalaureate and Beyond Longitudinal Study (B\&B:93/03) over a 10-year period to examine characteristics related to graduate degree enrollment, persistence, and completion among 1992-93 bachelor's degree recipients. B\&B includes students who were identified in the 1992-93 National Postsecondary Student Aid Study (NPSAS:93) as having earned a bachelor's degree during the 1992-93 academic year. NPSAS is based on a nationally representative sample of students enrolled in postsecondary education and provides detailed information on how students and their families pay for college, including the types and amounts of financial aid received. In the B\&B Study, the 1992-93 bachelor's degree recipients were interviewed in 1994 (B\&B:93/94), 1997 (B\&B:93/97), and 2003 (B\&B:93/03) to learn about their education and employment experiences after graduation.

The estimates presented in this report were produced using the B\&B:93/03 Data Analysis System (DAS). The DAS is a computer application that allows users to specify and generate their own tables and produces the design-adjusted standard errors necessary for testing the statistical significance of differences between numbers shown in the tables. It is available for public use on the NCES website at http://nces.ed.gov/das. Appendix B of this report contains additional information on the DAS. 


\section{Acknowledgments}

The authors wish to acknowledge important contributions to this report by many individuals. At MPR Associates, Ellen Bradburn and Laura Horn provided guidance throughout the process. Donna Fowler and Andrea Livingston edited the report, Annabelle Yang formatted the tables and prepared the figures, and Barbara Kridl managed the production process from beginning to end.

At NCES, Dennis Carroll oversaw the development of the report and shepherded it through the review process. Paula Knepper and Marilyn Seastrom provided thorough technical, methodological, and substantive reviews. We are grateful for thoughtful comments from a number of other reviewers, including Kenneth Redd (National Association of Student Financial Aid Administrators), Joan Burrelli (National Science Foundation), Larry Suter (National Science Foundation), Jacqueline King (Center for Policy Analysis), Carol Fuller (National Association of Independent Colleges and Universities), Catherine Millett (Educational Testing Service), Pat Smith (American Association of State Colleges and Universities), and Clifford Adelman (Office of Vocational and Adult Education). Duc-Le To of the Institute of Education Sciences also provided thoughtful comments and gathered and synthesized helpful comments from two anonymous external reviewers. 


\section{THIS PAGE INTENTIONALLY LEFT BLANK}




\section{Contents}

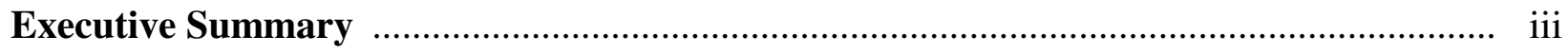

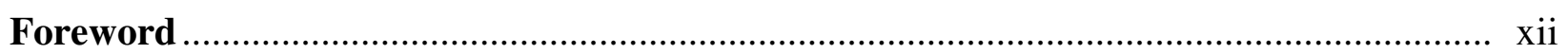

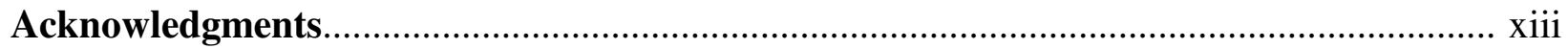

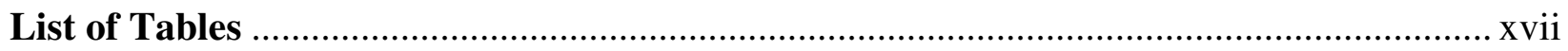

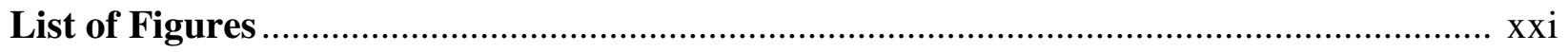

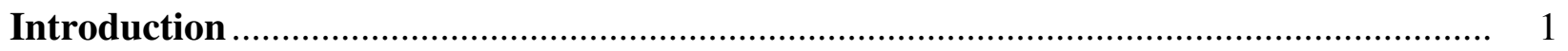

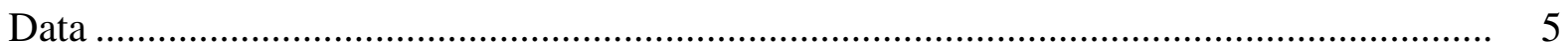

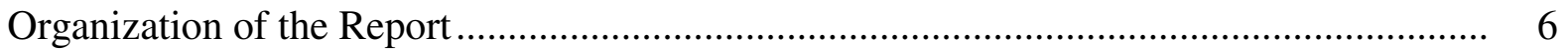

Characteristics Related to Graduate Degree Enrollment ......................................... 7

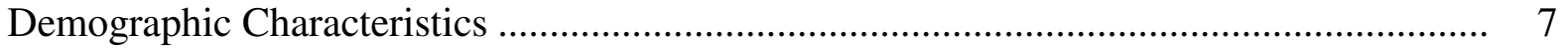

Undergraduate Education Characteristics ............................................................... 10

Enrollment in Multiple Graduate Degree Programs...................................................... 11

Marital and Parental Status ................................................................................ 14

Educational Expectations .................................................................................. 17

Timing of Entry Into Graduate School ................................................................... 18

Sources of Financial Aid and Borrowing for Graduate School...................................... 23

Characteristics of Enrollment ................................................................................ 29

Enrollment Intensity and Continuity of Enrollment ................................................ 29

Graduate Persistence and Attainment ................................................................... 33

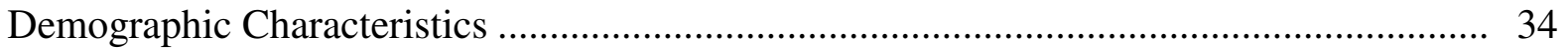

Marital and Parental Status .................................................................................. 37

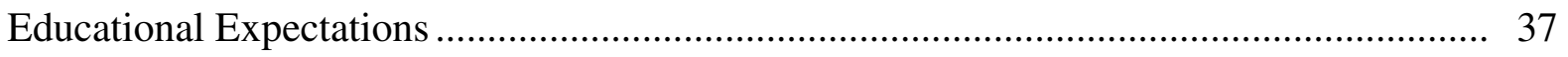

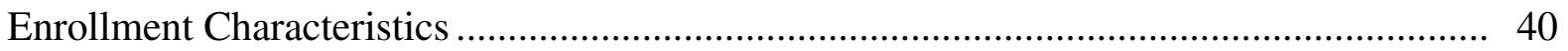

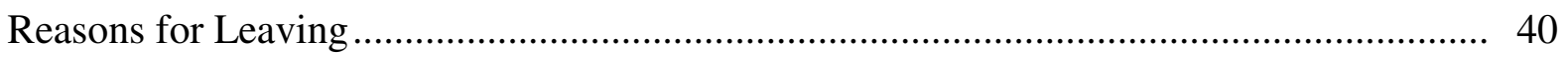

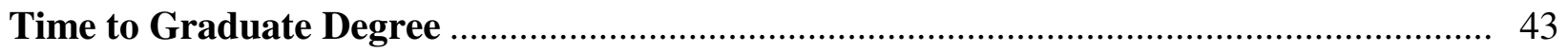

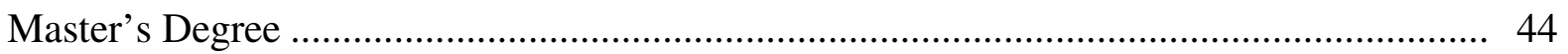

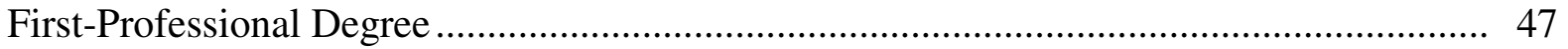

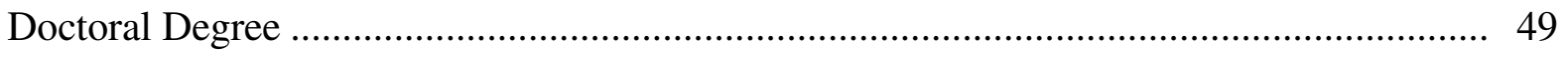


Page

Factors Related to Graduate Enrollment, Persistence, and Attainment........................ 55

Graduate Enrollment ......................................................................................... 56

Completion of Graduate Degrees ......................................................................... 58

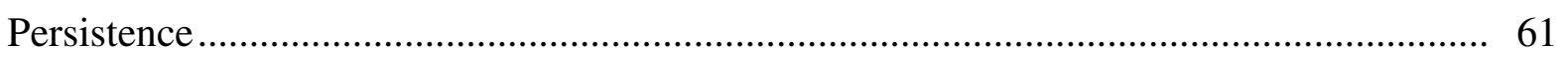

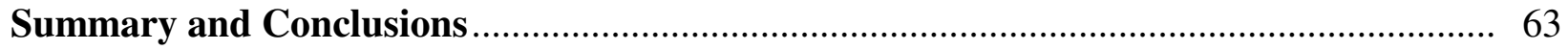

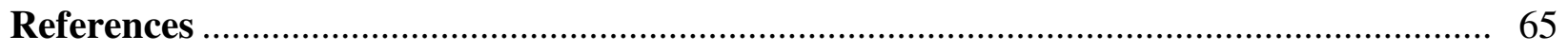

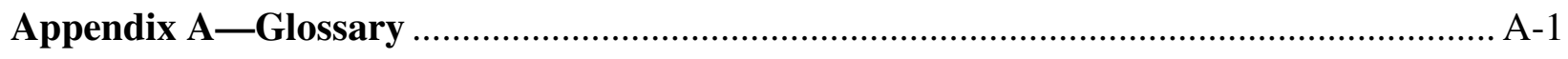

Appendix B-Technical Notes and Methodology …................................................ B-1 


\section{List of Tables}

Table

Page

\section{Executive Summary}

A Percentage distribution of 1992-93 bachela's degree recipients' highest graduate enrollment, by race/ethnicity and age: 2003 .

B Among 1992-93 bachelor's degree recipients who had enrolled ina graduate program by 2003 , percentage distribution of time and average time between bachelor's degree receipt and first graduate enrollment, by type of graduate enrollment and degree program

C Among 1992-93 bachelor's degree recipientswho had enrolled in a graduate degree program by 2003, percentage distribution of attainment and enrollment status in 2003, by highest graduate enrollment viii

\section{Text}

1 Percentage distribution of 1992-93 bachela's degree recipients' highest graduate enrollment, by student and institution characteristics: 2003

2 Percentage distribution of 1992-93 bachela's degree recipients' graduate enrollment, by student and institution characteristics: 2003

3 Percentage distribution of 1992-93 bachela's degree recipients' graduate enrollment, by gender and marital and parental status at bachelor's degree completion and in 1997

4 Percentage distribution of 1992-93 bachelor' sdegree recipients' graduate enrollment, by educational expectations at bachelor's degree completion.

5 Percentage distribution of 1992-93 bachelor' sdegree recipients' graduate enrollment, by gender, change in educational expectations, and educational expectations in 1997 .. 19

6 Among 1992-93 bachelor's degree recipientswho had enrolled in a graduate program by 2003 , average time and percentage distribution of time between bachelor's degree receipt and first graduate enrollment, by student and institution characteristics.... 
Table

7 Among 1992-93 bachelor's degree recipientswho had enrolled in a graduate program by 2003 , average time and percentage distribution of time between bachelor's degree receipt and first graduate enrollment, by gender and marital and parental status 1 year before graduate enrollment.

8 Among 1992-93 bachelor's degree recipientswho had enrolled in a graduate program by 2003 , average time and percentage distribution of time between bachelor's degree receipt and first graduate enrollment, by type of graduate enrollment and degree program

9 Percentage of graduate and first-professional students who received various types of financial aid, by student and institution characteristics: 2003-04.

10 Among 1992-93 bachelor's degree recipients with graduate degree enrollment, percentage who borrowed for graduate education and, among borrowers, average amount borrowed for graduate education, by student and institutional characteristics: 2003

11 Among 1992-93 bachelor's degree recipientswho had enrolled in a graduate program by 2003, percentage distribution of enrollment intensity while enrolled and percentage taking time off, by student and institution characteristics.

12 Among 1992-93 bachelor's degree recipientswho had enrolled in a graduate degree program by 2003, percentage distribution of attainment and enrollment status in 2003 , by highest graduate enrollment

13 Percentage distribution of major field ofstudy for the highest graduate degree earned by 1992-93 bachelor's degree recipients

14 Among 1992-93 bachelor's degree recipientswho had enrolled in a graduate degree program by 2003 , percentage distribution of attainment and enrollment status in 2003 , by selected student characteristics

15 Among 1992-93 bachelor's degree recipientswho enrolled in a graduate degree program by 2003 , percentage distribution of attainment and enrollment status in 2003 , by gender and marital and parental status 1 year before graduate enrollment .....

16 Among 1992-93 bachelor's degree recipientswho had enrolled in a graduate degree program by 2003, percentage distribution of attainment and enrollment status in 2003, by educational expectations at bachelor's degree completion.

17 Among 1992-93 bachelor's degree recipientswho had enrolled in a graduate degree program by 2003, percentage distribution of attainment and enrollment status in 2003, by graduate enrollment characteristics 
Table

Page

18a Among 1992-93 bachelor's degree recipientswho had earned a master's degree by 2003, average number of years and percentage distribution of time from first graduate enrollment to completion of master's degree, by selected student characteristics

18b Among 1992-93 bachelor's degree recipientswho had earned a master's degree by 2003, average number of years and percentage distribution of time from first graduate enrollment to completion of master's degree, by gender and marital and parental status 1 year before graduate enrollment

18c Among 1992-93 bachelor's degree recipientswho had earned a master's degree by 2003, average number of years and percentage distribution of time from first graduate enrollment to completion of master's degree, by graduate enrollment characteristics ...

19a Among 1992-93 bachelor's degree recipients who had earned afirst-professional degree by 2003, average number of years and percentage distribution of time from first graduate enrollment to completion of first-professional degree, by selected student characteristics

19b Among 1992-93 bachelor's degree recipientswho had earned a first-professional degree by 2003, average number of years and percentage distribution of time from first graduate enrollment to completion of first-professional degree, by gender and marital and parental status 1 year before graduate enrollment

19c Among 1992-93 bachelor's degree recipients who had earned afirst-professional degree by 2003, average number of years and percentage distribution of time from first graduate enrollment to completion of first-professional degree, by graduate enrollment characteristics

20a Among 1992-93 bachelor's degree recipients who had earned a doctoral degree by 2003, average number of years and percentage distribution of time from first graduate enrollment to completion of doctoral degree, by selected student characteristics

20b Among 1992-93 bachelor's degree recipientswho had earned a doctoral degree by 2003, average number of years and percentage distribution of time from first graduate enrollment to completion of doctoral degree, by gender and marital and parental status 1 year before graduate enrollment

20c Among 1992-93 bachelor's degree recipients who had earned a doctoral degree by 2003, average number of years and percentage distribution of time from first graduate enrollment to completion of doctoral degree, by graduate enrollment characteristics....

21 Among 1992-93 bachelor's degree recipients percentage who had enrolled in a graduate or first-professional degree program by 2003 and least squares coefficients and standard errors, by selected student characteristics 
Table

Page

22 Among 1992-93 bachelor's degree recipientswho had enrolled in a graduate degree program by 2003, percentage who had attained a graduate degree by 2003 and percentage who had attained a graduate degree or were still enrolled in a graduate program by 2003 and least squares coefficients and standard errors, by selected student characteristics

\section{Appendix B}

B-1 Standard errors for table 1: Percentage distribution of 1992-93 bachelor's degree recipients' highest graduate enrollment, by student and institution characteristics: 2003 


\section{List of Figures}

Figure

Page

Executive Summary

A Percentage distribution of 1992-93 bachela's degree recipients' highest graduate

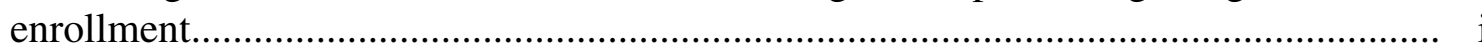

B Percentage of 1992-93 bachelor's degree recipients who had enrolled in single and multiple graduate degree programs by 2003 , by type of graduate degree program........ v

C Percentage of 1992-93 bachelor's degree recipients who had enrolled in a graduate degree program by 2003 , by undergraduate major and graduate degree program ......... vii

D Among 1992-93 bachelor's degree recipients who had enrolled in a graduate degree program by 2003 , percentage who had attained a graduate degree by 2003 , by gender and parental status 1 year before graduate enrollment

E Among 1992-93 bachelor's degree recipients who had earned a graduate degree by 2003, average number of years between first graduate enrollment and attainment of highest graduate degree, by highest graduate degree earned.

Text

1 Among 1992-93 bachelor's degree recipients who enrolled in a graduate degree program between 1997 and 2003, percentage who left for various reasons.

2 Among 1992-93 bachelor's degree recipientswho had earned a graduate degree by 2003, average number of years between first graduate enrollment and attainment of highest graduate degree, by highest graduate degree earned. 


\section{THIS PAGE INTENTIONALLY LEFT BLANK}




\section{Introduction}

Benefits of access to graduate education are wide-ranging. For the individual, there are notable financial returns as well as personal and intellectual benefits. For society as a whole, well-educated and highly trained professionals contribute to economic and technological development. It is important therefore, to understand the potential barriers that prevent access to and persistence in graduate education. The variety of choices that students face after earning a bachelor's degree may affect their future educational and career paths. For example, decisions about employment, marriage, and whether to have children may be related to graduates' likelihood of enrolling in graduate school. The financial burden of undergraduate debts may also carry some weight in whether bachelor's degree recipients choose to pursue a graduate education or enter the workforce. Once students enroll in a graduate degree program, completion of that program is not guaranteed. The same factors listed above as well as other variables are investigated in this report as they relate to the likelihood of graduate enrollment and degree completion.

This report uses data from the Baccalaureate and Beyond Longitudinal Study (B\&B), which includes students who had completed or expected to complete a bachelor's degree between July 1992 and June 1993. These graduates were interviewed in 1993, then located and surveyed again in 1994 and 1997. The final follow-up took place in 2003, 10 years after the cohort had completed a bachelor's degree. This report provides a descriptive analysis of this cohort's entrance into graduate school and persistence in and completion of a graduate degree program 10 years after bachelor's degree completion. ${ }^{1}$

An examination by demographic characteristics, such as gender and race/ethnicity, of enrollment in graduate school is addressed in this report. It is clear that women represent an increasing percentage of graduate degree completers than they did just 25 years ago (U.S. Department of Education 2006; Bowen and Rudenstine 1992). In 2003-04, women earned 59 percent of all master's degrees and 48 percent of all doctoral degrees. Figures from 1979-80 indicate that women earned 49 percent of all master's degrees and 30 percent of all doctoral degrees (U.S. Department of Education 2006).

\footnotetext{
${ }^{1}$ Graduate degree can refer to a master's, doctoral, and/or a first-professional degree.
} 
Using data from the B\&B:93/97 follow-up, Perna (2004) showed that a larger proportion of women than men enrolled in programs at the master's degree level and that a smaller proportion enrolled in doctoral ( 2 vs. 4 percent) and first-professional degree programs ( 5 vs. 10 percent). After controlling for several financial, academic, and demographic variables using multinomial logit analyses (undergraduate education debt, dependency status and income, cumulative undergraduate grade point average (GPA), SAT/ACT quartile, parents' educational attainment, primary language spoken at home, and the value students place on financial success and family ties), differences in men and women's enrollment patterns disappeared at the master's level but remained at the first-professional and doctoral level.

Researchers have reported differences in graduate enrollment patterns among students across racial/ethnic groups. Looking specifically at the 1993/97 Baccalaureate and Beyond Longitudinal Study (B\&B:93/97) follow-up, Perna (2004) reported that a higher proportion of Asian/Pacific Islander students enrolled in a first-professional degree program (7 percent) than students in any other racial/ethnic group by 1997. Even after controlling for the same variables mentioned above, Asian/Pacific Islander students were more likely to enroll in a firstprofessional degree program than White students. Perna also reported that an equal proportion of Black and White students enrolled in master's and first-professional degree programs. After controlling for several variables (major field of study, marital status, parental status, amount of undergraduate debt, income and dependency status in 1992-93, cumulative undergraduate gradepoint average, SAT/ACT quartile, parents' highest education, whether English was spoken in the home, a derived factor measuring success in the labor market, a derived factor measuring the importance of doing intellectually stimulating work, and parental involvement), however, the odds of Black students enrolling in a master's or first-professional degree program to not enrolling is higher than it is for White students.

Age may also be a factor when students are considering enrolling in graduate school. Older students may feel pressure to begin a family and career. Clune, Nuñez, and Choy (2001) reported that age was an important factor in graduate enrollment. Students who were age 22 or younger when they earned their bachelor's degree were more likely than older students to enroll in a graduate degree program during the 4 years following graduation (Clune, Nuñez, and Choy 2001; Bradburn et al. 2003).

Family responsibilities, such as those associated with being married or having children, may impose limitations on graduates' time and their likelihood of applying to, enrolling in, and completing a graduate degree program. Clune, Nuñez, and Choy (2001) found that marriage and parenthood were related more to graduate enrollment and attainment for women than for men. Among women, rates of enrollment in and completion of a first-professional or doctoral degree 
program were higher among those who were single before earning a bachelor's degree than among those who were married. Similar patterns were reported for women who were parents. Among men, those who were married before earning a bachelor's degree had lower rates of enrollment in a first-professional or doctoral degree program than single men. Although marriage and parenthood were not generally related to men's graduate degree attainment, Price (2005) reported a positive relationship between the time of graduate enrollment and degree completion among married men. Men who were married at the time they began graduate school were on average 4 percent more likely to graduate than their unmarried counterparts, and they completed their degree about 4 months faster than unmarried men. Married women were not any more likely to graduate than single women, but they did complete their degree about 2.5 months sooner.

Factors related to a student's undergraduate education, such as undergraduate major, grade point average, and selectivity of the undergraduate institution may contribute to a student's likelihood of enrolling in and success in graduate school. Graduates with bachelor's degrees in the life, social, and physical sciences were more likely to enroll in a graduate degree program before entering the labor force than graduates with degrees in engineering or computer science (Tsapogas and Cahalan 1996). This finding is consistent with the one reported by Millett (2003) that undergraduates who had majored in specific disciplines as opposed to applied fields were twice as likely to apply to graduate or first-professional school.

Ethington and Smart (1986) reported that the selectivity of the undergraduate institution attended had a positive effect on graduate enrollment for men: those men who had attended more selective institutions were more likely than their peers in less selective institutions to enroll in graduate school. Academic achievement (average undergraduate GPAs) and social integration (involvement with peers and faculty) at the undergraduate institution were reported to be strong predictors of entry into a graduate program regardless of gender (Ethington and Smart 1986; Millett 2003; Choy and Geis 1997; Hearn 1987). High undergraduate GPAs for men, however, were a stronger predictor for them, whereas high levels of social integration were a stronger predictor for women (Ethington and Smart 1986).

The price of earning a bachelor's degree is continually rising, and as a consequence students are borrowing more money to complete their undergraduate education (The College Board 2003). Several researchers have examined the role of debt in the transition to graduate school. Among 1992-93 bachelor's degree recipients 1 year after graduation, Choy and Geis (1997) found that graduates without undergraduate education loans were slightly more likely to be enrolled than those with loans, after controlling for age at bachelor's degree attainment, GPA, and bachelor's degree major. Results from the 1997 Baccalaureate and Beyond (B\&B:93/97) follow-up suggest that the percentage of 1992-93 bachelor's degree recipients who applied for 
admission to a doctoral or first-professional degree program was slightly less among those who borrowed than among those who did not borrow (38 vs. 42 percent) (McCormick et al. 1999). Millett (2003) confirmed these findings after controlling for several variables. Students with debt ranging between $\$ 10,000$ and $\$ 15,000$ were one and a half times less likely to apply to a graduate degree program than students with no debt. ${ }^{2}$ When looking at enrollment in, not just admittance to, graduate school, Choy (2000) and Millett (2003) found that the effect of undergraduate borrowing diminished when examining data from up to 4 years later. That is, there was no longer a measurable difference between borrowers and nonborrowers in the percentage who enrolled in a graduate degree program. Weiler (1991) also showed that indebtedness did not have an effect on entry into graduate school.

Perhaps one of the biggest choices that students are faced with after earning a bachelor's degree is the choice between entering the workforce or pursuing a graduate education. Results from the 1994 Baccalaureate and Beyond follow-up showed that 88 percent of students entered the work force and were not attending graduate school (Heller 2001). Among those working in 1994, 63 percent were working in a professional field and 32 percent were working in a clerical or other technical position. By 1997, the percentage of graduates working in professional occupations increased to 79 percent (Heller 2001).

The cost of pursuing a graduate degree can be estimated by the direct cost of tuition and fees, less any financial aid, and the estimated wages that students lose by not entering the workforce immediately after college graduation. Weiler (1991), using data from the third followup of the High School and Beyond Longitudinal Study of 1980 Seniors (HS\&B-Sr:80/86), investigated the relationship between estimated forgone wages, based on bachelor's degree major, and graduate degree enrollment. Estimated forgone wages have a negative effect on enrollment in a master's degree program, but no effect on enrollment in a doctoral or firstprofessional degree program.

Andrieu and St. John (1993) did a similar type of study although they investigated the relationship between expected earnings and graduate persistence for students attending public universities. In their study, graduate students enrolled in fields in which expected earnings were low were less likely to stay enrolled than students enrolled in fields in which expected earnings were high.

\footnotetext{
2 Millett's work examined the experiences of applying to and enrolling in graduate school for students who indicated they wanted to earn a doctoral degree.
} 


\section{Data}

This report uses data collected over a 10-year period from the 1993/03 Baccalaureate and Beyond Longitudinal Study (B\&B:93/03) to examine characteristics related to graduate degree enrollment, persistence, and completion among 1992-93 bachelor's degree recipients. Base-year information on this cohort was collected as part of the 1992-93 National Postsecondary Student Aid Study (NPSAS:93). Graduates were interviewed again in 1994, 1997, and 2003.

NPSAS:93 included about 1,100 institutions and was based on a nationally representative sample of all students enrolled in postsecondary education institutions, including undergraduate, graduate, and first-professional students. One of a series of similar studies conducted every 4 to 5 years since 1987, NPSAS:93 includes a sample from more than 16 million undergraduates who were enrolled at some time between July 1, 1992 and June 30, 1993. The survey frames for NPSAS were built from the 1990-91 "Institutional Characteristics Survey" of the Integrated Postsecondary Education Data System (IPEDS-IC), and lists of students were obtained from each participating institution. The estimates presented in this report are based on the results of interviews with approximately 9,000 bachelor's degree recipients each year (1994, 1997, and 2003) from a sampling frame of about 12,500; these bachelor's degree recipients represent the approximately 1.2 million bachelor's degree recipients in the United States (U.S. Department of Education 2004). Excluded from the final sample were 760 students who, during the B\&B interview or from transcripts, were determined not to have earned a bachelor's degree during the 1992-93 academic year (see appendix B for more detail). The weighted overall response rate was 74 percent, reflecting an institution response rate (in 1992) of 88 percent and a student response rate (in 2003) of 83 percent. The data presented in this report cover the 50 states, District of Columbia (DC), and Puerto Rico.

All comparisons made in the text were tested using Student's $t$ statistic. All differences cited were statistically significant at the .05 level. Appendix B provides information about the formula used and more detail on significance levels. Standard errors for all estimates are available at http://nces.ed.gov/das/library/reports.asp.

The sample used for this analysis consists of the NPSAS:93 respondents who earned a bachelor's degree in 1992-93 and participated in all three B\&B interviews: 1994, 1997, and 2003. The report focused on highest degree program enrolled in, and information that was missing in 1994 or 1997 was updated in 2003 when possible. A panel weight was created based on respondents to all three surveys. Consequently, some estimates presented here may differ slightly from previously published data. 


\section{Organization of the Report}

This report contains five additional sections. The first of these describes characteristics related to graduate enrollment, the type of programs in which students enrolled, the extent to which 1992-93 graduates had enrolled in a graduate program, and the average amount of time it took them to enroll in a graduate program after completing a bachelor's degree. The second examines the enrollment characteristics of those who entered a graduate degree program. The third is a discussion of graduate persistence and attainment. The fourth discusses the average time taken to complete a graduate degree. The final section explores important characteristics related to students' likelihood of enrolling in and completing a graduate degree program while controlling for other factors. For the sake of convenience graduate and first-professional degree programs are referred to as graduate degrees in the body of the report. Graduate refers to education at the master's, doctoral, and first-professional degree levels. 


\section{Characteristics Related to Graduate Degree Enrollment}

Among the 1992-93 bachelor's degree recipients, ${ }^{3} 29$ percent had enrolled in a master's, doctoral, or first-professional degree program within 4 years of completing college, with enrollment the highest during the first year after receiving a bachelor's degree (Clune, Nuñez, and Choy 2001). Of those who had enrolled, about three-fourths (76 percent) were in a master's degree program, 14 percent in a first-professional degree program, and 10 percent in a doctoral degree program (McCormick et al. 1999). In fact, by 1997, 15 percent had attained a master's, doctoral, or first-professional degree (Clune, Nuñez, and Choy 2001).

By 2003, a decade after completing a bachelor's degree, 40 percent of 1992-93 graduates had enrolled in a graduate degree program (table 1). Table 1 looks at the highest graduate enrollment among 1992-93 bachelor's degree recipients. Master's degree programs were the most common, with 31 percent of bachelor's degree recipients enrolled in them, compared with 5 percent in first-professional degree programs and 4 percent in doctoral degree programs. ${ }^{4}$ Looking specifically at graduates who enrolled in a master's degree program, 7 percent enrolled in an MBA program (Master of Business Administration), 9 percent enrolled in an MEd program (Master of Education), and 14 percent enrolled in another type of master's degree program. This section describes the characteristics related to graduate enrollment, the type of programs in which the 1992-93 graduates enrolled, and the extent to which they had enrolled in a graduate degree program.

\section{Demographic Characteristics}

It is important to consider the demographic characteristics related to graduate enrollment. Differences in graduate enrollment by race, gender, and age are addressed in this section. Graduate enrollment was related to a number of demographic characteristics, such as graduates' gender, race/ethnicity, and age and parents' education. Although gender differences were not apparent in graduate enrollment as a whole, there was a relationship between gender and

\footnotetext{
3 Bachelor's degree recipients or graduates refer to people who responded to this study. Students refer to bachelor's degree recipients who enrolled in a graduate or first-professional degree program. Graduate degree can refer to a master's, doctoral, and/or a first-professional degree.

${ }^{4}$ In this report first-professional degree programs include the following degree programs: chiropractic, dentistry, law, medicine, optometry, osteopathic medicine, pharmacy, podiatry, divinity/theology, or veterinary medicine. MBA programs are treated as master's degree programs in this report.
} 
Table 1. Percentage distribution of 1992-93 bachelor's degree recipients' highest graduate enrollment, by student and institution characteristics: 2003

\begin{tabular}{|c|c|c|c|c|c|c|c|}
\hline \multirow[b]{2}{*}{$\begin{array}{l}\text { Student and institution } \\
\text { characteristics }\end{array}$} & \multirow[b]{2}{*}{$\begin{array}{r}\text { No } \\
\text { enroll- } \\
\text { ment } \\
\end{array}$} & \multicolumn{6}{|c|}{ Highest graduate enrollment } \\
\hline & & $\begin{array}{r}\text { Total } \\
\text { any } \\
\text { enroll- } \\
\text { ment } \\
\end{array}$ & MBA & MEd & $\begin{array}{r}\text { Other } \\
\text { master's }\end{array}$ & $\begin{array}{r}\text { First- } \\
\text { profes- } \\
\text { sional } \\
\end{array}$ & Doctoral \\
\hline Total & 60.0 & 40.0 & 7.3 & 8.8 & 14.4 & 5.0 & 4.5 \\
\hline \multicolumn{8}{|l|}{ Gender } \\
\hline Male & 61.4 & 38.6 & 8.9 & 4.0 & 13.9 & 6.2 & 5.5 \\
\hline Female & 58.9 & 41.1 & 5.9 & 12.8 & 14.9 & 4.0 & 3.6 \\
\hline \multicolumn{8}{|l|}{ Race/ethnicity $^{1}$} \\
\hline White & 60.8 & 39.2 & 7.0 & 9.2 & 14.2 & 4.5 & 4.3 \\
\hline Black & 54.6 & 45.4 & 8.3 & 7.5 & 19.1 & 5.3 & 5.2 \\
\hline Hispanic & 56.3 & 43.7 & 9.4 & 9.7 & 13.9 & 4.7 & 6.1 \\
\hline Asian/Pacific Islander & 58.5 & 41.5 & 8.3 & 3.3 & 12.7 & 13.6 & 3.7 \\
\hline \multicolumn{8}{|c|}{ Age at bachelor's degree completion } \\
\hline 22 or younger & 51.8 & 48.3 & 7.8 & 9.4 & 16.9 & 7.7 & 6.5 \\
\hline $23-24$ & 67.9 & 32.1 & 5.8 & 8.2 & 11.2 & 3.3 & 3.6 \\
\hline $25-29$ & 72.8 & 27.2 & 6.5 & 5.8 & 11.5 & 2.0 & 1.6 \\
\hline 30 or older & 63.8 & 36.2 & 8.2 & 9.9 & 14.6 & 1.9 & 1.6 \\
\hline \multicolumn{8}{|c|}{ Highest education level by either parent } \\
\hline Less than high school & 66.3 & 33.7 & 8.7 & 8.7 & 10.5 & 2.8 & 2.9 \\
\hline High school or equivalency & 66.4 & 33.7 & 6.8 & 9.4 & 12.0 & 3.2 & 2.2 \\
\hline Some postsecondary & 61.0 & 39.1 & 8.3 & 8.8 & 14.6 & 4.3 & 3.0 \\
\hline Bachelor's degree & 60.3 & 39.7 & 6.0 & 7.9 & 15.4 & 5.0 & 5.3 \\
\hline Advanced degree & 51.5 & 48.5 & 8.2 & 9.0 & 16.4 & 7.6 & 7.3 \\
\hline \multicolumn{8}{|c|}{ Bachelor's degree-granting institution } \\
\hline Non-doctoral-granting & 64.8 & 35.2 & 5.5 & 12.2 & 12.9 & 2.6 & 2.1 \\
\hline Doctoral-granting & 60.8 & 39.2 & 6.4 & 7.8 & 14.2 & 5.4 & 5.4 \\
\hline \multicolumn{8}{|l|}{ Private not-for-profit 4-year } \\
\hline Non-doctoral-granting & 58.7 & 41.3 & 8.4 & 9.0 & 15.1 & 4.4 & 4.4 \\
\hline Doctoral-granting & 49.6 & 50.4 & 10.5 & 7.0 & 17.2 & 9.4 & 6.3 \\
\hline Other & 66.7 & 33.3 & 11.0 & 4.3 & 13.7 & 2.2 & 2.1 \\
\hline
\end{tabular}

See notes at end of table. 
Table 1. Percentage distribution of 1992-93 bachelor's degree recipients' highest graduate enrollment, by student and institution characteristics: 2003 -Continued

\begin{tabular}{|c|c|c|c|c|c|c|c|}
\hline \multirow[b]{2}{*}{$\begin{array}{l}\text { Student and institution } \\
\text { characteristics }\end{array}$} & \multirow[b]{2}{*}{$\begin{array}{r}\text { No } \\
\text { enroll- } \\
\text { ment } \\
\end{array}$} & \multicolumn{6}{|c|}{ Highest graduate enrollment } \\
\hline & & $\begin{array}{r}\text { Total } \\
\text { any } \\
\text { enroll- } \\
\text { ment } \\
\end{array}$ & MBA & MEd & $\begin{array}{r}\text { Other } \\
\text { master's } \\
\end{array}$ & $\begin{array}{r}\text { First- } \\
\text { profes- } \\
\text { sional } \\
\end{array}$ & Doctoral \\
\hline \multicolumn{8}{|l|}{ Baccalaureate degree major } \\
\hline Business and management & 74.8 & 25.3 & 14.1 & 2.8 & 5.5 & 2.4 & 0.5 \\
\hline Education & 49.9 & 50.1 & 1.8 & 32.3 & 10.5 & 2.4 & 3.1 \\
\hline Engineering & 60.8 & 39.2 & 11.7 & 0.5 & 19.8 & 1.8 & 5.4 \\
\hline Health professions & 63.8 & 36.3 & 3.2 & 3.2 & 24.8 & 3.6 & 1.6 \\
\hline Public affairs/social services & 64.0 & 36.0 & 3.4 & 3.1 & 26.0 & 2.2 & 1.3 \\
\hline Biological sciences & 33.2 & 66.9 & 3.1 & 2.7 & 16.2 & 22.7 & 22.1 \\
\hline Mathematics and other sciences & 51.4 & 48.6 & 6.0 & 6.5 & 16.4 & 5.2 & 14.6 \\
\hline Social science & 52.1 & 47.9 & 10.0 & 5.0 & 17.5 & 9.9 & 5.5 \\
\hline History & 48.2 & 51.9 & 5.2 & 18.2 & 15.9 & 8.1 & 4.4 \\
\hline Humanities & 59.3 & 40.7 & 4.1 & 7.7 & 19.2 & 5.1 & 4.8 \\
\hline Psychology & 45.1 & 55.0 & 7.1 & 14.2 & 21.0 & 5.2 & 7.5 \\
\hline Other & 65.7 & 34.3 & 4.3 & 8.5 & 14.1 & 5.1 & 2.4 \\
\hline \multicolumn{8}{|l|}{ Bachelor's degree GPA } \\
\hline Under 2.5 & 76.5 & 23.5 & 4.4 & 6.3 & 9.9 & 1.6 & 1.3 \\
\hline $2.5-2.99$ & 64.4 & 35.6 & 7.3 & 8.3 & 13.8 & 3.3 & 3.0 \\
\hline $3.0-3.49$ & 56.6 & 43.4 & 7.6 & 9.7 & 15.0 & 6.2 & 4.9 \\
\hline 3.5 or above & 47.8 & 52.2 & 9.0 & 10.1 & 17.7 & 7.5 & 7.8 \\
\hline \multicolumn{8}{|l|}{ Undergraduate debt } \\
\hline Did not borrow & 60.1 & 39.9 & 7.0 & 8.2 & 14.3 & 5.5 & 4.8 \\
\hline$\$ 1-4,999$ & 61.7 & 38.3 & 8.4 & 8.1 & 14.1 & 3.8 & 3.9 \\
\hline$\$ 5,000-9,999$ & 59.3 & 40.7 & 7.8 & 9.9 & 15.4 & 3.9 & 3.7 \\
\hline$\$ 10,000-14,999$ & 61.4 & 38.6 & 6.2 & 11.1 & 12.2 & 4.8 & 4.4 \\
\hline$\$ 15,000$ or more & 58.7 & 41.3 & 7.2 & 8.4 & 16.2 & 5.2 & 4.4 \\
\hline
\end{tabular}

\footnotetext{
${ }^{1}$ Black includes African American, Pacific Islander includes Native Hawaiian, and Hispanic includes Latino. Included in the totals but not shown separately are data for American Indian/Alaska Native respondents and those who identified themselves with another race not shown. Race categories exclude Hispanic origin unless specified.

NOTE: Estimates include students from the 50 states, DC, and Puerto Rico. Detail may not sum to totals because of rounding. Standard error tables are available at http://nces.ed.gov/das/library/reports.asp.

SOURCE: U.S. Department of Education, National Center for Education Statistics, 1993/03 Baccalaureate and Beyond Longitudinal Study (B\&B:93/03).
}

enrollment in specific types of degree programs (table 1). As an example, men were more likely than women to enroll in MBA (9 vs. 6 percent), first-professional (6 vs. 4 percent), and doctoral degree programs (6 vs. 4 percent), and women were much more likely than men to enroll in MEd programs (13 vs. 4 percent). 
Black graduates were more likely than White graduates to enroll in a graduate degree program (45 vs. 39 percent). However, using data from the B\&B:93/97 follow-up, McCormick et al. (1999) reported that among students who applied to a graduate degree program, Black graduates were admitted at a lower rate than Asian/Pacific Islander, Hispanic, and White graduates. Looking at enrollment in first-professional programs specifically, Asian/Pacific Islander graduates were more likely than graduates in other racial/ethnic groups to enroll within 10 years of earning a bachelor's degree (14 vs. 5 percent).

The likelihood of enrolling in a graduate degree program was also related to age at bachelor's degree completion. In general, younger graduates were more likely to enroll than older graduates. For example, 48 percent of graduates age 22 or younger at the time of bachelor's degree completion enrolled in a graduate or first-professional degree program, compared with 36 percent of those age 30 or older. However, graduates age 30 or older when they completed a bachelor's degree were just as likely to enroll in an MBA or MEd program as their peers age 22 or younger (MBA: 8 percent each and MEd 10 percent vs. 9 percent).

Bachelor's degree recipients' enrollment in a graduate degree program was related to their parents' highest education level. Enrollment in a graduate degree program increased from 34 percent among graduates whose parents had a high school education or less to 49 percent among those whose parents had a graduate degree.

\section{Undergraduate Education Characteristics}

Undergraduate education may often be seen as the foundation for preparing students for graduate education. What might students do to prepare themselves for a graduate education during their undergraduate study? Some factors, such as undergraduate grade point average (GPA), undergraduate institution type, and field of study are related to the likelihood of a student enrolling in a graduate degree program.

The cumulative GPAs of graduates were positively related to their rates of graduate enrollment. Higher achieving bachelor's degree recipients were more likely to have enrolled in a graduate degree program by 2003 than their lower achieving counterparts (52 vs. 24 to 43 percent, table 1).

Graduates of private not-for-profit 4-year doctorate-granting institutions were more likely to have enrolled in a graduate degree program by 2003 than those who attended any other type of institution. Fifty percent of graduates from these types of institutions had enrolled in a graduate or first-professional degree program, compared with 33 to 41 percent of graduates from other 
types of institutions. This was especially apparent among graduates enrolling in first-professional degree programs, where graduates in private not-for-profit doctorate-granting institutions were more likely to enroll as students in other types of institutions (9 vs. 2 to 5 percent).

The frequency of enrollment in a graduate or first-professional degree program was also related to undergraduate major. Graduates who had majored in business as undergraduates were less likely to enroll in a graduate degree program than graduates with other majors ( $25 \mathrm{vs}$. 34 to 67 percent), while graduates who had majored in biological sciences were more likely to enroll than graduates who had majored in other fields (67 vs. 25 to 55 percent). This was especially apparent among graduates who enrolled in a first-professional or doctoral degree program. Graduates who had majored in biological sciences as undergraduates were more likely to enroll in a first-professional or doctoral program than graduates who had majored in any other field (23 and 22 percent, respectively, vs. 2 to 10 percent and .5 to 15 percent, respectively). Furthermore, graduates who had majored in mathematics as undergraduates were generally more likely than graduates with other majors to enroll in a doctoral degree program (15 vs. .5 to 7 percent).

\section{Enrollment in Multiple Graduate Degree Programs}

To get a more complete picture of the enrollment experiences of 1992-93 bachelor's degree recipients, this analysis looks at whether students enrolled in more than one graduate degree program. The sequence of students' enrollment in various programs, their original degree expectations, and specific details about each program are not discussed, however. For example, students who enrolled in both master's and doctoral degree programs may have originally been on a doctoral degree track, but decided to switch to a master's degree program to expedite entry into the workforce. Conversely, some students working toward a master's degree may have decided that earning a doctoral degree would prove to be more valuable, and for some, completing a master's degree is a prerequisite for acceptance into a doctoral degree program while for others, completing a master's degree is a by-product of a doctoral program.

Over the 10-year study period, 1 in 10 of the bachelor's degree recipients enrolled in more than one graduate degree program: 5 percent enrolled in multiple master's degree programs, 2 percent enrolled in both a master's and a doctoral degree program, ${ }^{5}$ and 3 percent enrolled in both a first-professional and another graduate degree program (table 2). Younger graduates were more likely than older graduates to enroll in multiple degree programs ( 13 vs. 5 to 8 percent), as

\footnotetext{
${ }^{5}$ In some institutions and programs, the master's degree is required before admission to the doctoral program. B\&B considers these to be two separate programs. During each follow-up interview (1994, 1997, and 2003), students were asked to report each program in which they enrolled.
} 


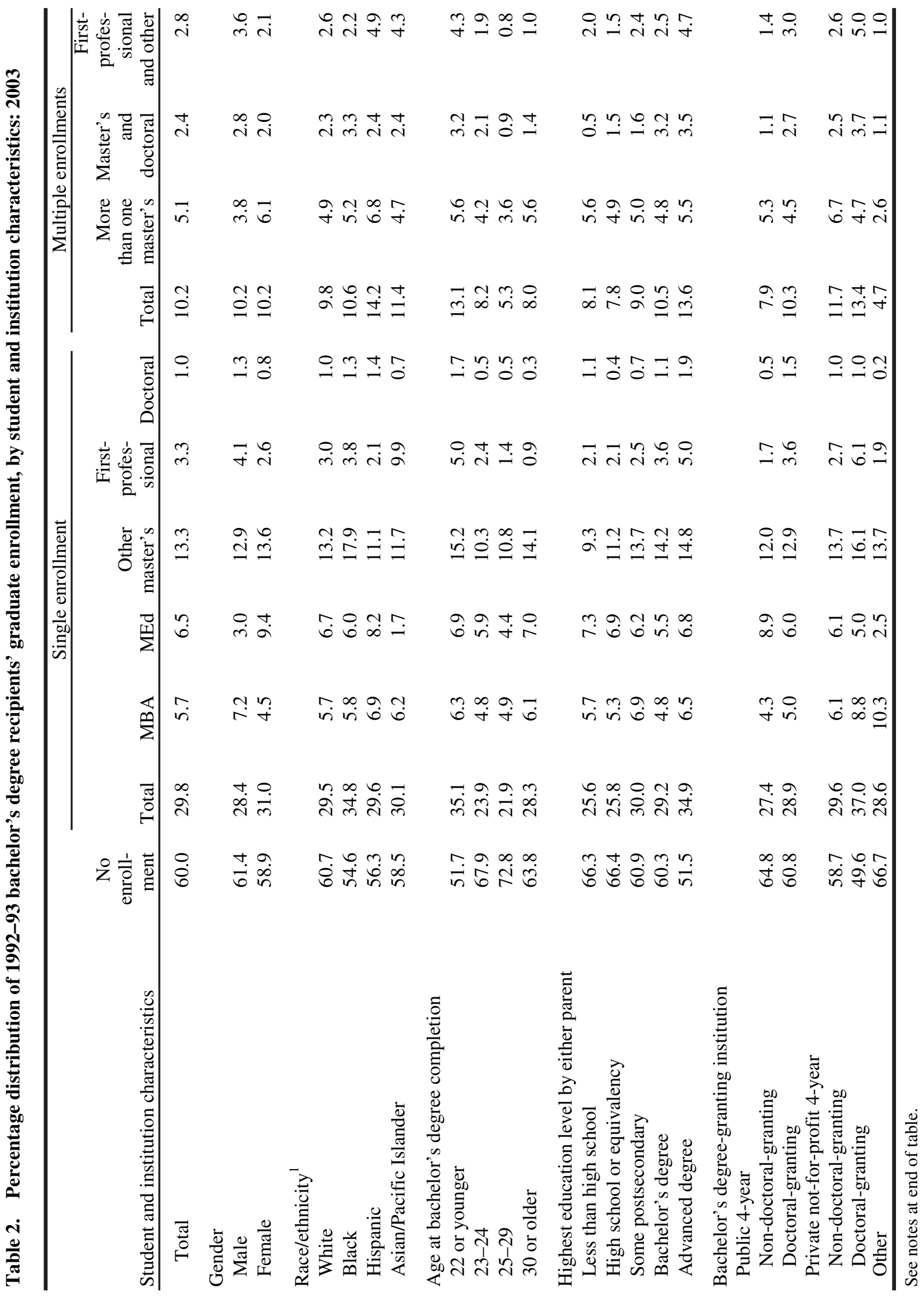




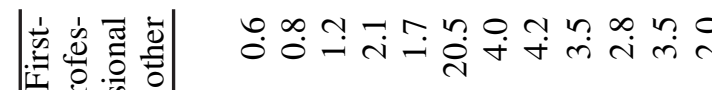

$\stackrel{\infty}{0} \stackrel{\infty}{\dot{m}} \stackrel{m}{+}$

$\stackrel{\infty}{i} \vec{i} \hat{i}$ i

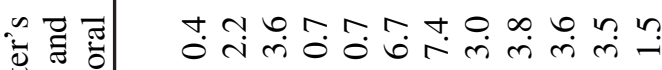

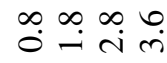

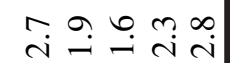

$\sum^{\frac{\pi}{2}} \frac{\delta}{0}$

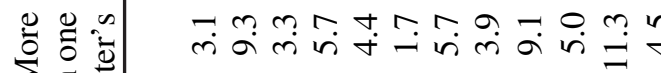

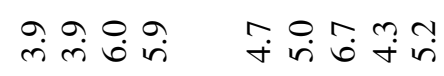

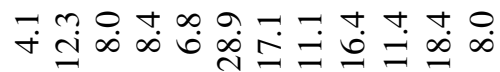

in

ঢ̆

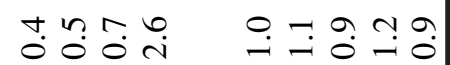

๑

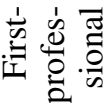

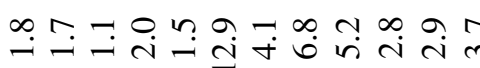

$\stackrel{\rightarrow}{\sim} \stackrel{4}{\circ} \stackrel{+}{\circ}$

mे

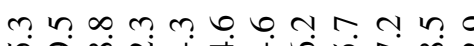

ம

$\infty 900$

min

농

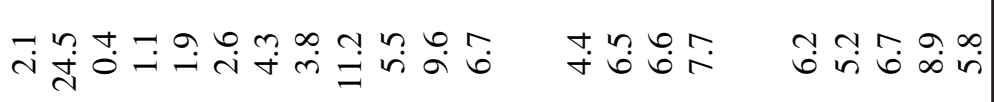

= ๆ

๓ุ

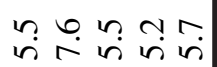

-

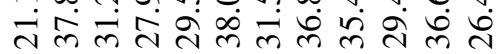

$0 \cdot \because+$

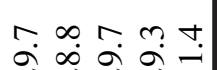


were those who had majored in biological sciences than those with other majors ( 29 vs. 4 to 18 percent). ${ }^{6}$

\section{Marital and Parental Status}

Family responsibilities, such as those associated with being married or having dependent children, may impose limitations on graduates' time and their likelihood of applying to and enrolling in graduate school. Regardless of gender, graduates who were married at the time they completed a bachelor's degree were less likely to enroll in a graduate degree program than graduates who were single (never married), divorced, separated, or widowed (32 vs. 42 to 43 percent; table 3). ${ }^{7}$ The trend also was true for marital status in 1997. That is, graduates who were married 4 years after completing a bachelor's degree were less likely to enroll in a graduate degree program than their unmarried counterparts ( $35 \mathrm{vs.} 45$ percent). To gain a better understanding of the differences in enrollment patterns of single, unmarried graduates and married graduates, enrollment among these groups was examined at the program level. When examining enrollment (in single programs) by type of program, single graduates were more likely to enroll in a first-professional or doctoral degree program than married graduates (firstprofessional: 10 vs. 3 percent; doctoral: 3 vs. 1 percent). However, no detectable differences were found between married graduates and single graduates in their likelihood of enrolling in an MBA program (14 and 15 percent, respectively), but married graduates were more likely to enroll in an MEd program (21 vs. 14 percent).

Among single graduates, there were some gender differences in enrollment patterns. Single women were more likely than single men to enroll in a graduate degree program (45 vs. 40 at bachelor's degree and 48 vs. 42 percent in 1997).

Parenthood was negatively associated with enrollment in graduate school. Graduates who reported having dependent children in 1997 were less likely to enroll in a graduate degree program by 2003 than their counterparts who did not report having children (33 vs. 42 percent). This pattern was especially prevalent among bachelor's degree recipients who enrolled in firstprofessional, doctoral, and multiple degree programs that included a first-professional degree and a master's graduate degree program. Although no significant difference was detected, there was an apparent difference in enrolling in graduate school between women and men with dependent

\footnotetext{
${ }^{6}$ Enrollment in multiple degree programs is defined as enrolling in more than one graduate degree program. Students could enroll in more than one master's, doctoral, or first-professional degree program, or could enroll in a combination of master's, doctoral, or first-professional degree programs.

7 Twenty-four percent of students were married or cohabiting at the time they earned their bachelor's degree, 60 percent were single, never married, and 3 percent were divorced, widowed, or separated.
} 


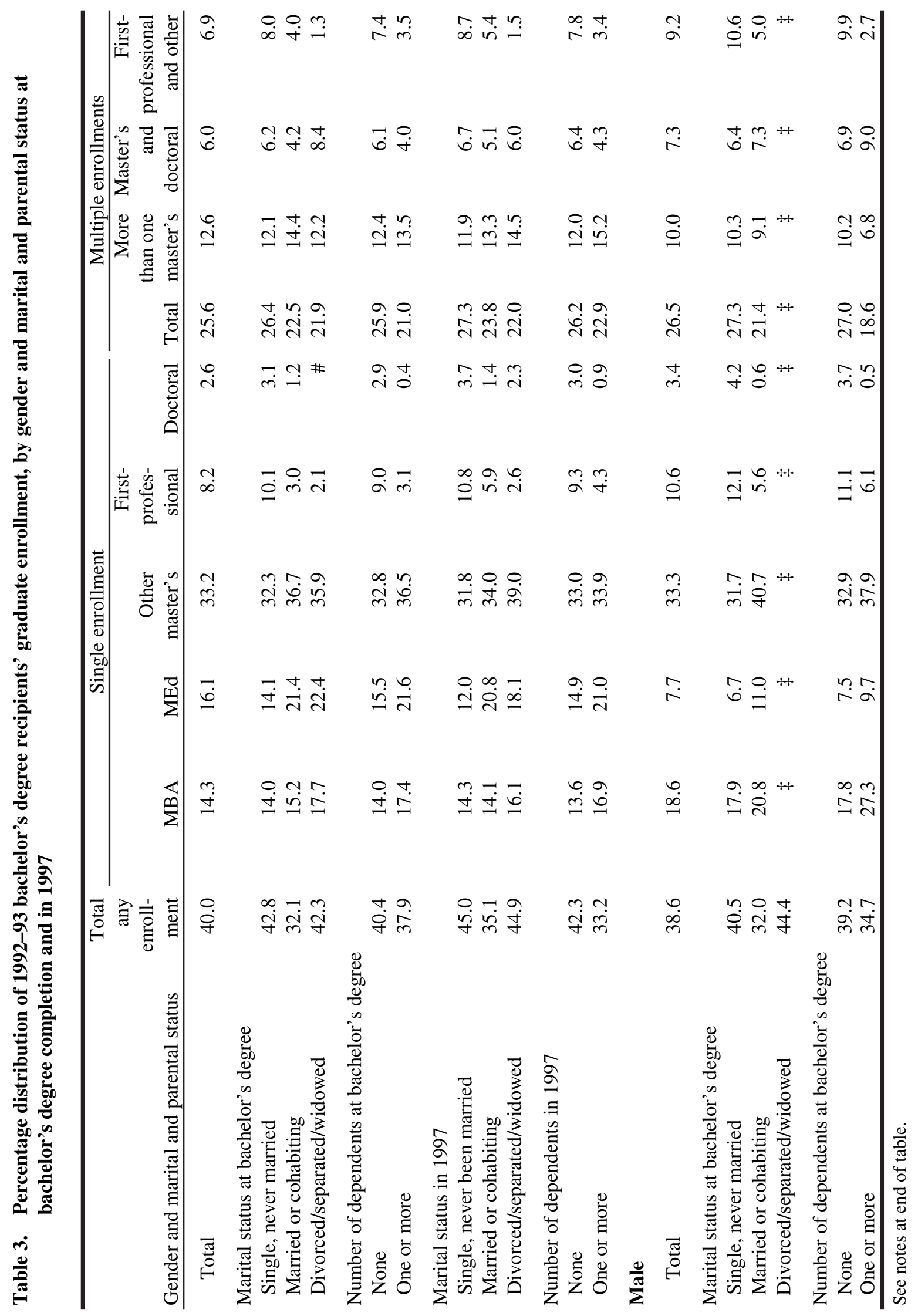




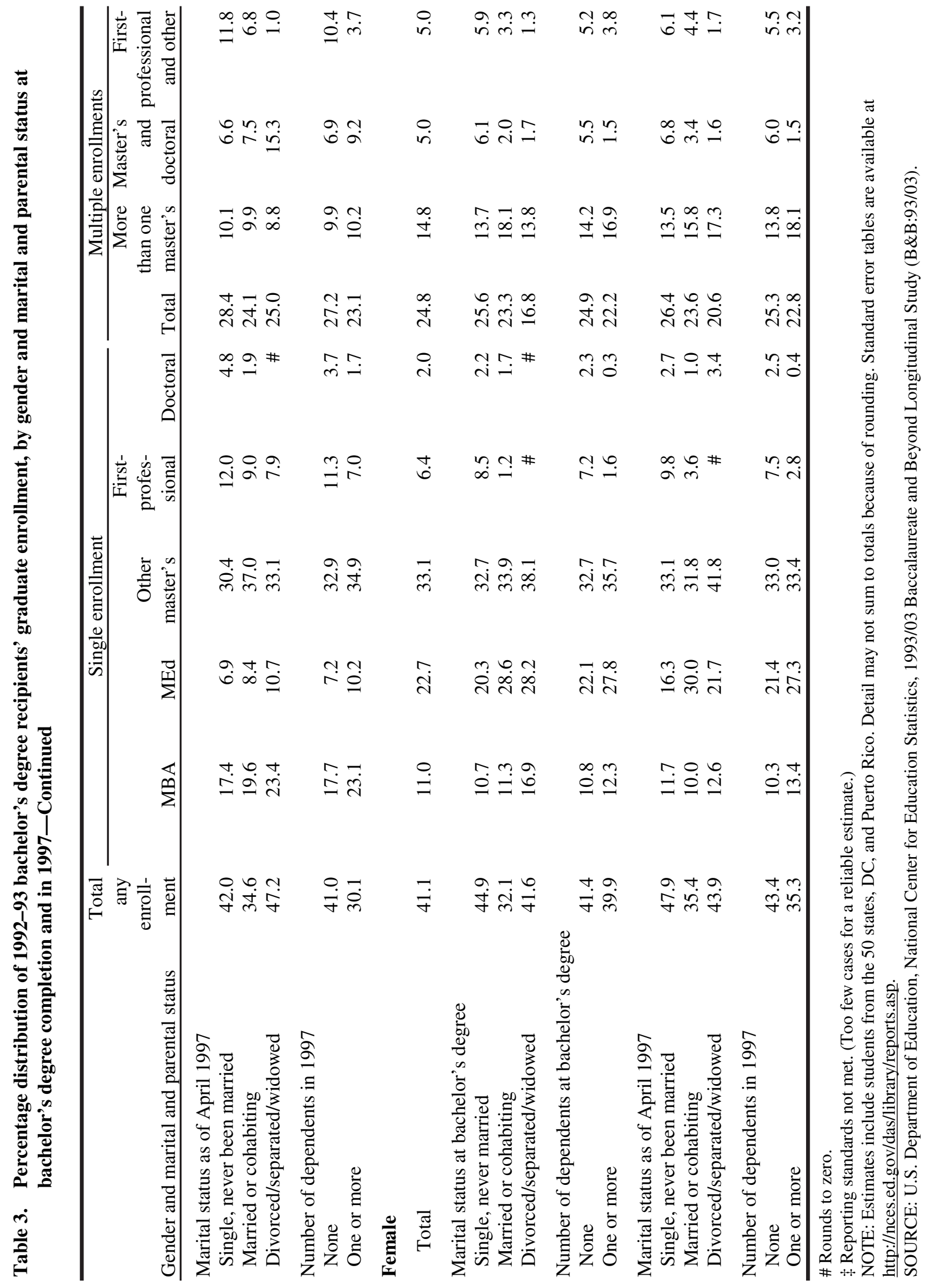


children. Thirty-five percent of men who were parents when they completed a bachelor's degree later enrolled in a graduate degree program, compared with 41 percent of women.

\section{Educational Expectations}

Although graduate degree enrollments have increased since the 1970s (U.S. Department of Education 2002), the percentage of bachelor's degree recipients who enroll in graduate school is less than the percentage who state they would like to attain a graduate degree at the time of bachelor's degree completion in 1992-93. Among 1992-93 bachelor's degree recipients, less than one-half (35 percent) of graduates who expected to earn a master's degree enrolled in a graduate degree program. This gap between expectations and enrollment was especially evident among those with doctoral degree aspirations. While 63 percent of bachelor's degree recipients who expected to earn a doctoral degree enrolled in graduate school, they were more likely to enroll in a master's than a doctoral degree program: a total of 41 percent had their highest enrollment in a master's degree program (6 percent in an MBA program, 12 percent in an MEd program, and 23 percent in another master's degree program), compared with 15 percent whose highest enrollment was in a doctoral degree program (table 4). However, graduates with doctoral degree aspirations were more likely than graduates with bachelor's and master's degree goals to enroll in a doctoral degree program.

Table 4. Percentage distribution of 1992-93 bachelor's degree recipients' graduate enrollment, by educational expectations at bachelor's degree completion

\begin{tabular}{|c|c|c|c|c|c|c|c|c|}
\hline \multirow[b]{3}{*}{$\begin{array}{l}\text { Educational expectations at } \\
\text { bachelor's degree completion }\end{array}$} & \multirow{3}{*}{$\begin{array}{r}\text { No } \\
\text { enroll- } \\
\text { ment } \\
\end{array}$} & \multicolumn{7}{|c|}{ Highest graduate enrollment } \\
\hline & & \multirow{2}{*}{$\begin{array}{r}\text { Total } \\
\text { any } \\
\text { enroll- } \\
\text { ment } \\
\end{array}$} & \multirow{2}{*}{$\begin{array}{r}\text { Total } \\
\text { any } \\
\text { master's } \\
\end{array}$} & \multicolumn{3}{|c|}{ Master's enrollment } & \multirow{2}{*}{$\begin{array}{r}\text { First- } \\
\text { profes- } \\
\text { sional } \\
\end{array}$} & \multirow[b]{2}{*}{ Doctora } \\
\hline & & & & MBA & MEd & $\begin{array}{r}\text { Other } \\
\text { master's }\end{array}$ & & \\
\hline Total & 60.0 & 40.0 & 30.5 & 7.3 & 8.8 & 14.4 & 5.0 & 4.5 \\
\hline Bachelor's degree or less & 83.3 & 16.7 & 13.4 & 3.1 & 3.7 & 6.5 & 2.4 & 1.0 \\
\hline Master's degree & 64.6 & 35.4 & 32.7 & 9.0 & 9.8 & 13.9 & 1.5 & 1.2 \\
\hline First-professional degree & 30.5 & 69.5 & 21.5 & 6.3 & 3.8 & 11.4 & 36.1 & 12.0 \\
\hline Doctoral degree & 37.0 & 63.0 & 40.9 & 6.0 & 11.6 & 23.2 & 7.4 & 14.7 \\
\hline
\end{tabular}

NOTE: 15 percent of all graduates had educational expectations of a bachelor's degree or less, 58 percent expected to earn a master's degree, 6 percent expected to earn a first-professional degree, and 21 percent expected to earn a doctoral degree. Estimates include students from the 50 states, DC, and Puerto Rico. Detail may not sum to totals because of rounding. Standard error tables are available at http://nces.ed.gov/das/library/reports.asp. SOURCE: U.S. Department of Education, National Center for Education Statistics, 1993/03 Baccalaureate and Beyond Longitudinal Study (B\&B:93/03). 
Similarly, the majority (70 percent) of bachelor's degree recipients with first-professional degree aspirations enrolled in a graduate degree program, and 36 percent enrolled in a firstprofessional degree program as their highest enrollment. A larger proportion of graduates with first-professional degree aspirations enrolled in that program than those with other degree expectations. Of graduates with master's degree expectations, just over one-third (35 percent) enrolled in graduate school, and 33 percent enrolled in a master's degree program.

In looking at changes in graduates' educational expectations from 1993 to 1997 and the impact of those changes on rates of graduate and first-professional degree enrollment, graduates whose educational expectations increased from the 1993 to 1997 interviews were more likely than all other groups of graduates to enroll in a graduate degree program (59 vs. 30 to 42 percent) (table 5).

Graduates with doctoral and first-professional degree expectations in 1997 were more likely to have enrolled in a graduate degree program than their counterparts with lower educational expectations (83 and 84 percent, respectively, vs. 7 and 42 percent). There were some gender differences in enrollment patterns, however. Women with master's degree expectations in 1997 were more likely to have enrolled in a graduate program than men with these expectations (44 vs. 39 percent), while men with first-professional degree expectations were more likely to have enrolled than women with similar expectations (91 vs. 73 percent). Graduates' educational expectations and completion of a graduate degree program are discussed in a later section of this report.

\section{Timing of Entry Into Graduate School}

Of 1992-93 bachelor's degree recipients who had enrolled in a graduate degree program by 2003, some 36 percent enrolled within 1 year of earning a bachelor's degree; 28 percent took between 1 and 3 years; 16 percent took between 3 and 5 years; and 20 percent took more than 5 years (table 6). On average, students enrolled within 2 or 3 years of earning a bachelor's degree. The average time between bachelor's degree receipt and first graduate enrollment was related to various student and institution characteristics, for example: gender, race/ethnicity, undergraduate major, age, undergraduate institution type, and marital status. There appeared to be some differences in how long students waited to enroll based on their gender and race/ethnicity. On average, men waited less time to enroll than women (2.5 vs. 2.8 years). Asian/Pacific Islander students enrolled within 2.1 years, on average. However, it has been shown that male and Asian/Pacific Islander students were more likely to major in undergraduate fields in which students typically take less time off between bachelor's degree completion and graduate enrollment (such as life and physical sciences and engineering) (Bradburn et al. 2003). 
Table 5. Percentage distribution of 1992-93 bachelor's degree recipients' graduate enrollment, by gender, change in educational expectations, and educational expectations in 1997

\begin{tabular}{|c|c|c|c|c|c|c|c|c|}
\hline \multirow[b]{2}{*}{ Educational expectations } & \multirow[b]{2}{*}{$\begin{array}{r}\text { No } \\
\text { enroll- } \\
\text { ment } \\
\end{array}$} & \multicolumn{7}{|c|}{ Highest graduate enrollment } \\
\hline & & $\begin{array}{r}\text { Total } \\
\text { any } \\
\text { enroll- } \\
\text { ment } \\
\end{array}$ & $\begin{array}{r}\text { Total } \\
\text { any } \\
\text { master's } \\
\end{array}$ & MBA & MEd & $\begin{array}{r}\text { Other } \\
\text { master's }\end{array}$ & $\begin{array}{r}\text { First- } \\
\text { profes- } \\
\text { sional } \\
\end{array}$ & Doctoral \\
\hline Total & 60.0 & 40.0 & 30.5 & 7.3 & 8.8 & 14.4 & 5.0 & 4.5 \\
\hline \multicolumn{9}{|l|}{$\begin{array}{l}\text { Change in degree expectations from } \\
\text { bachelor's to } 1997\end{array}$} \\
\hline Expectations lowered & 70.2 & 29.9 & 21.4 & 4.4 & 5.3 & 11.8 & 5.5 & 2.9 \\
\hline Expectations raised & 40.9 & 59.1 & 42.5 & 9.9 & 12.9 & 19.7 & 7.9 & 8.7 \\
\hline Remained the same & 58.1 & 42.0 & 33.1 & 8.3 & 9.9 & 15.0 & 4.3 & 4.6 \\
\hline \multicolumn{9}{|l|}{ Educational expectations in 1997} \\
\hline Bachelor's degree & 93.2 & 6.8 & 5.4 & 1.2 & 1.1 & 3.2 & 0.8 & 0.7 \\
\hline Master's degree & 58.2 & 41.8 & 39.6 & 10.5 & 11.3 & 17.7 & 1.1 & 1.2 \\
\hline First-professional degree & 17.0 & 83.0 & 8.4 & 2.4 & 1.0 & 5.1 & 65.8 & 8.8 \\
\hline Doctoral degree & 16.2 & 83.9 & 54.7 & 8.4 & 17.8 & 28.5 & 3.6 & 25.6 \\
\hline \multicolumn{9}{|l|}{ Male } \\
\hline Total & 61.4 & 38.6 & 26.9 & 8.9 & 4.0 & 13.9 & 6.2 & 5.5 \\
\hline \multicolumn{9}{|l|}{$\begin{array}{l}\text { Change in degree expectations from } \\
\text { bachelor's to } 1997\end{array}$} \\
\hline Expectations lowered & 70.9 & 29.1 & 18.4 & 4.3 & 1.8 & 12.3 & 7.0 & 3.8 \\
\hline Expectations raised & 45.4 & 54.6 & 32.7 & 8.7 & 6.9 & 17.2 & 9.3 & 12.5 \\
\hline Remained the same & 59.2 & 40.8 & 30.0 & 11.4 & 4.4 & 14.2 & 5.4 & 5.4 \\
\hline \multicolumn{9}{|l|}{ Educational expectations in 1997} \\
\hline Bachelor's degree & 93.3 & 6.7 & 5.2 & 1.7 & 0.3 & 3.3 & 0.8 & 0.7 \\
\hline Master's degree & 60.6 & 39.4 & 36.8 & 14.0 & 5.1 & 17.7 & 1.2 & 1.4 \\
\hline First-professional degree & 8.9 & 91.1 & 9.9 & 3.8 & 0.2 & 5.9 & 71.4 & 9.7 \\
\hline Doctoral degree $(\mathrm{PhD}, \mathrm{EdD}, \mathrm{DPH})$ & 19.0 & 81.0 & 44.9 & 7.6 & 9.5 & 27.8 & 4.0 & 32.1 \\
\hline \multicolumn{9}{|l|}{ Female } \\
\hline Total & 58.9 & 41.1 & 33.6 & 5.9 & 12.8 & 14.9 & 4.0 & 3.6 \\
\hline \multicolumn{9}{|l|}{$\begin{array}{l}\text { Change in degree expectations from } \\
\text { bachelor's to } 1997\end{array}$} \\
\hline Expectations lowered & 69.7 & 30.3 & 23.8 & 4.4 & 8.0 & 11.4 & 4.2 & 2.3 \\
\hline Expectations raised & 37.5 & 62.5 & 49.8 & 10.7 & 17.4 & 21.7 & 6.8 & 5.9 \\
\hline Remained the same & 57.0 & 43.0 & 35.9 & 5.6 & 14.7 & 15.6 & 3.3 & 3.9 \\
\hline \multicolumn{9}{|l|}{ Educational expectations in 1997} \\
\hline Bachelor's degree & 93.0 & 7.0 & 5.5 & 0.7 & 1.8 & 3.0 & 0.7 & 0.7 \\
\hline Master's degree & 56.3 & 43.7 & 41.8 & 7.9 & 16.1 & 17.8 & 1.0 & 1.0 \\
\hline First-professional degree & 26.9 & 73.1 & 6.6 & 0.7 & 1.9 & 4.1 & 58.9 & 7.6 \\
\hline Doctoral degree $(\mathrm{PhD}, \mathrm{EdD}, \mathrm{DPH})$ & 13.7 & 86.3 & 62.9 & 9.1 & 24.8 & 29.0 & 3.2 & 20.2 \\
\hline
\end{tabular}

NOTE: Estimates include students from the 50 states, DC, and Puerto Rico. Detail may not sum to totals because of rounding. Standard error tables are available at http://nces.ed.gov/das/library/reports.asp.

SOURCE: U.S. Department of Education, National Center for Education Statistics, 1993/03 Baccalaureate and Beyond Longitudinal Study (B\&B:93/03). 
Table 6. Among 1992-93 bachelor's degree recipients who had enrolled in a graduate program by 2003, average time and percentage distribution of time between bachelor's degree receipt and first graduate enrollment, by student and institution characteristics

\begin{tabular}{|c|c|c|c|c|c|}
\hline \multirow[b]{2}{*}{ Student and institution characteristics } & \multirow{2}{*}{$\begin{array}{r}\text { Average } \\
\text { number of } \\
\text { years }\end{array}$} & \multicolumn{4}{|c|}{ Percentage distribution } \\
\hline & & $\begin{array}{l}1 \text { year } \\
\text { or less }\end{array}$ & $\begin{array}{r}\text { More than } \\
1 \text { to } 3 \text { years } \\
\end{array}$ & $\begin{array}{r}\text { More than } \\
3 \text { to } 5 \text { years }\end{array}$ & $\begin{array}{r}\text { More than } \\
5 \text { years }\end{array}$ \\
\hline Total & 2.7 & 35.9 & 28.3 & 16.2 & 19.5 \\
\hline \multicolumn{6}{|l|}{ Gender } \\
\hline Male & 2.5 & 39.5 & 27.3 & 14.5 & 18.7 \\
\hline Female & 2.8 & 33.0 & 29.2 & 17.5 & 20.2 \\
\hline \multicolumn{6}{|l|}{ Race/ethnicity ${ }^{1}$} \\
\hline White & 2.7 & 35.9 & 28.1 & 16.4 & 19.6 \\
\hline Black & 3.0 & 28.5 & 31.0 & 16.3 & 24.3 \\
\hline Hispanic & 2.8 & 38.6 & 24.5 & 14.9 & 22.1 \\
\hline Asian/Pacific Islander & 2.1 & 44.0 & 31.0 & 15.7 & 9.2 \\
\hline \multicolumn{6}{|l|}{ Age at bachelor's degree completion } \\
\hline 22 or younger & 2.5 & 37.0 & 29.0 & 16.2 & 17.9 \\
\hline $23-24$ & 2.9 & 33.5 & 25.6 & 18.6 & 22.3 \\
\hline $25-29$ & 3.1 & 32.2 & 28.3 & 13.4 & 26.2 \\
\hline 30 or older & 2.5 & 38.4 & 30.4 & 13.5 & 17.6 \\
\hline \multicolumn{6}{|l|}{ Highest education level by either parent } \\
\hline Less than high school & 3.1 & 30.1 & 32.8 & 15.8 & 21.3 \\
\hline High school or equivalency & 2.9 & 32.5 & 27.6 & 15.5 & 24.4 \\
\hline Some postsecondary & 2.9 & 36.8 & 25.6 & 13.8 & 23.8 \\
\hline Bachelor's degree & 2.7 & 34.4 & 29.2 & 18.6 & 17.9 \\
\hline Advanced degree & 2.4 & 39.0 & 29.0 & 16.4 & 15.7 \\
\hline \multicolumn{6}{|l|}{ Bachelor's degree-granting institution } \\
\hline \multicolumn{6}{|l|}{ Public 4-year } \\
\hline Non-doctoral-granting & 2.5 & 38.7 & 29.0 & 14.9 & 17.4 \\
\hline Doctoral-granting & 3.0 & 31.7 & 25.3 & 21.1 & 21.9 \\
\hline \multicolumn{6}{|l|}{ Private not-for-profit 4-year } \\
\hline Non-doctoral-granting & 2.8 & 30.3 & 30.8 & 18.9 & 20.0 \\
\hline Doctoral-granting & 2.5 & 38.2 & 29.3 & 12.8 & 19.7 \\
\hline \multicolumn{6}{|l|}{ Baccalaureate degree major } \\
\hline Business and management & 3.3 & 28.0 & 22.3 & 22.2 & 27.6 \\
\hline Education & 2.8 & 32.0 & 32.4 & 15.3 & 20.2 \\
\hline Engineering & 2.0 & 46.5 & 30.2 & 12.7 & 10.6 \\
\hline Health professions & 2.9 & 35.3 & 26.8 & 17.5 & 20.5 \\
\hline Public affairs/social services & 3.5 & 31.7 & 27.3 & 10.6 & 30.3 \\
\hline Biological sciences & 1.8 & 47.6 & 31.3 & 9.9 & 11.2 \\
\hline Mathematics and other sciences & 2.0 & 47.7 & 26.7 & 10.9 & 14.7 \\
\hline Social science & 2.5 & 33.1 & 31.0 & 20.8 & 15.1 \\
\hline History & 2.3 & 34.9 & 30.8 & 22.2 & 12.2 \\
\hline Humanities & 2.8 & 36.5 & 25.2 & 15.5 & 22.8 \\
\hline Psychology & 2.8 & 36.0 & 30.2 & 14.3 & 19.5 \\
\hline Other & 2.8 & 34.5 & 28.0 & 15.6 & 21.9 \\
\hline
\end{tabular}

See notes at end of table. 
Table 6. Among 1992-93 bachelor's degree recipients who had enrolled in a graduate program by 2003, average time and percentage distribution of time between bachelor's degree receipt and first graduate enrollment, by student and institution characteristics-Continued

\begin{tabular}{|c|c|c|c|c|c|}
\hline \multirow[b]{2}{*}{ Student and institution characteristics } & \multirow{2}{*}{$\begin{array}{r}\text { Average } \\
\text { number of } \\
\text { years }\end{array}$} & \multicolumn{4}{|c|}{ Percentage distribution } \\
\hline & & $\begin{array}{l}1 \text { year } \\
\text { or less }\end{array}$ & $\begin{array}{r}\text { More than } \\
1 \text { to } 3 \text { years }\end{array}$ & $\begin{array}{l}\text { More than } \\
3 \text { to } 5 \text { years }\end{array}$ & $\begin{array}{r}\text { More than } \\
5 \text { years }\end{array}$ \\
\hline Bachelor's degree GPA & & & & & \\
\hline Under 2.5 & 3.2 & 26.8 & 27.6 & 22.3 & 23.3 \\
\hline $2.5-2.99$ & 3.1 & 28.8 & 28.2 & 18.9 & 24.1 \\
\hline $3.0-3.49$ & 2.5 & 38.0 & 30.0 & 14.4 & 17.7 \\
\hline 3.5 or above & 2.3 & 42.9 & 27.1 & 13.7 & 16.3 \\
\hline
\end{tabular}

${ }^{1}$ Black includes African American, Pacific Islander includes Native Hawaiian, and Hispanic includes Latino. Included in the totals but not shown separately are data for American Indian/Alaska Native respondents and those who identified themselves with another race not shown. Race categories exclude Hispanic origin unless specified.

NOTE: Estimates include students from the 50 states, DC, and Puerto Rico. Detail may not sum to totals because of rounding. Standard error tables are available at http://nces.ed.gov/das/library/reports.asp.

SOURCE: U.S. Department of Education, National Center for Education Statistics, 1993/03 Baccalaureate and Beyond Longitudinal Study (B\&B:93/03).

Students with undergraduate majors in biological sciences and in engineering and mathematics generally waited fewer years to enroll (1.8 and 2.0 years each, respectively) than students with other majors (2.3 to 3.5 years). Younger students and those age 30 or older waited less time to enroll in a graduate degree program than students ages 23-24 (2.5 vs. 2.9 years).

Students who had attained a bachelor's degree from a public 4-year doctorate-granting institution typically waited longer to enroll in a graduate degree program than their counterparts at public 4-year non-doctorate-granting institutions (3.0 vs. 2.5 years). The opposite was true in the private sector. Students who had attended private not-for-profit doctorate-granting institutions typically waited less time to enroll than those at private not-for-profit non-doctorategranting institutions ( 2.5 vs. 2.8 years).

Students who were single 1 year before graduate enrollment waited less time, on average, to enroll than students who were married, divorced, separated, or widowed regardless of gender (2.1 vs. 3.7 to 3.8 years; table 7). Also, regardless of gender, students who had no children 1 year before graduate enrollment typically took less time to enroll than those with children.

Compared with students in any other type of graduate degree program, doctoral degree students typically waited the least amount of time between earning a bachelor's degree and enrolling in graduate school, while students in an MBA program waited the most time to enroll (table 8). The majority (65 percent) of students who enrolled in a doctoral degree program enrolled within 1 year of earning a bachelor's degree, as did about one-half of students who enrolled in a first-professional degree program. 
Table 7. Among 1992-93 bachelor's degree recipients who had enrolled in a graduate program by 2003, average time and percentage distribution of time between bachelor's degree receipt and first graduate enrollment, by gender and marital and parental status 1 year before graduate enrollment

\begin{tabular}{lrrrrrr}
\hline & $\begin{array}{c}\text { Average } \\
\text { number of }\end{array}$ & & \multicolumn{3}{c}{ Percentage distribution } \\
\cline { 6 - 7 } Gender and marital and parental status & years & $\begin{array}{r}1 \text { year } \\
\text { or less }\end{array}$ & $\begin{array}{r}\text { More than } \\
1 \text { to 3 years }\end{array}$ & $\begin{array}{r}\text { More than } \\
3 \text { to 5 years }\end{array}$ & $\begin{array}{r}\text { More than } \\
5 \text { years }\end{array}$ \\
\hline Total & 2.7 & 35.9 & 28.3 & 16.2 & 19.5
\end{tabular}

Marital status year before graduate enrollment

Single

Married/cohabit as married

Divorced/separated/widowed

Number of dependent children year

before graduate enrollment

None

One or more

Male

$$
\text { Total }
$$

Marital status year before graduate enrollment

\section{Single}

Married/cohabit as married

Divorced/separated/widowed

Number of dependent children year

before graduate enrollment

None

One or more

Female

$$
\text { Total }
$$

Marital status year before graduate enrollment

\section{Single}

Married/cohabit as married

Divorced/separated/widowed

Number of dependent children year

before graduate enrollment

None

One or more

$\begin{array}{ll}2.1 & 42.4 \\ 3.8 & 22.5 \\ 3.7 & 28.4\end{array}$

42.4
22.5

28.4

$2.5 \quad 37.3$

$3.7 \quad 27.8$

2.5

39.5

27.3

14.5

18.7

31.1

19.9

29.0

16.6

17.1

24.3

13.2

34.7

$20.7 \quad 33.4$

$20.4 \quad 31.4$ 
Table 8. Among 1992-93 bachelor's degree recipients who had enrolled in a graduate program by 2003, average time and percentage distribution of time between bachelor's degree receipt and first graduate enrollment, by type of graduate enrollment and degree program

\begin{tabular}{|c|c|c|c|c|c|}
\hline \multirow[b]{2}{*}{ Graduate degree program } & \multirow{2}{*}{$\begin{array}{r}\text { Average } \\
\text { number of } \\
\text { years } \\
\end{array}$} & \multicolumn{4}{|c|}{ Percentage distribution } \\
\hline & & $\begin{array}{l}1 \text { year } \\
\text { or less }\end{array}$ & $\begin{array}{r}\text { More than } \\
1 \text { to } 3 \text { years }\end{array}$ & $\begin{array}{r}\text { More than } \\
3 \text { to } 5 \text { years }\end{array}$ & $\begin{array}{r}\text { More than } \\
5 \text { years }\end{array}$ \\
\hline Total & 2.7 & 35.9 & 28.3 & 16.2 & 19.5 \\
\hline \multicolumn{6}{|l|}{ Highest graduate enrollment } \\
\hline MBA & 3.5 & 24.4 & 25.4 & 21.4 & 28.8 \\
\hline MEd & 3.0 & 28.1 & 31.4 & 19.2 & 21.3 \\
\hline Other master's & 2.8 & 32.8 & 29.4 & 16.6 & 21.2 \\
\hline First-professional & 1.8 & 49.2 & 30.5 & 10.2 & 10.1 \\
\hline Doctoral & 1.2 & 65.4 & 22.2 & 7.3 & 5.1 \\
\hline \multicolumn{6}{|l|}{ All graduate enrollment } \\
\hline MBA & 4.2 & 16.1 & 21.3 & 22.8 & 39.8 \\
\hline $\begin{array}{l}\text { MEd or post-master's certificate } \\
\text { in education }\end{array}$ & 3.4 & 23.9 & 28.9 & 21.1 & 26.2 \\
\hline Other master's & 2.9 & 30.6 & 30.1 & 16.7 & 22.5 \\
\hline First-professional & 2.2 & 44.3 & 27.5 & 13.2 & 15.0 \\
\hline Doctoral & 1.8 & 54.0 & 22.1 & 11.8 & 12.1 \\
\hline Multiple enrollment & & & & & \\
\hline More than one master's & 1.5 & 48.7 & 34.2 & 15.2 & 2.0 \\
\hline Master's and doctoral & 1.1 & 67.9 & 21.4 & 7.2 & 3.5 \\
\hline First-professional and other & 0.9 & 63.3 & 32.0 & 3.8 & 1.0 \\
\hline
\end{tabular}

NOTE: Estimates include students from the 50 states, DC, and Puerto Rico. Detail may not sum to totals because of rounding. Standard error tables are available at http://nces.ed.gov/das/library/reports.asp.

SOURCE: U.S. Department of Education, National Center for Education Statistics, 1993/03 Baccalaureate and Beyond Longitudinal Study (B\&B:93/03).

Students who pursued multiple degree programs generally waited less time to enroll in a graduate degree program than those who enrolled in a single degree program. Students who enrolled in both a master's and doctoral degree program and those who enrolled in both a firstprofessional and other graduate degree program typically waited about 1 year to enroll.

\section{Sources of Financial Aid and Borrowing for Graduate School}

As mentioned previously (table 6), 1992-93 bachelor's degree recipients waited an average of 2 to 3 years to enroll in graduate school. Because a lack of financial resources may have contributed to their delay in enrolling, it is important to consider how students finance their graduate education. Information on tuition and costs of graduate attendance is not available for $\mathrm{B} \& \mathrm{~B}$; however, there is some information on sources of financial aid for graduate education that 
will be discussed below. Choy and Moskovitz (1998) used data from the 1995-96 National Postsecondary Student Aid Study (NPSAS:96) to examine patterns of financial aid receipt among students in graduate degree programs. Because 1992-93 graduates waited 2 to 3 years to enroll in graduate school, the data from NPSAS:96 approximately coincide with their typical entry year. Among all students who enrolled in a graduate or first-professional degree program in 1995-96, some 52 percent received some form of aid, 30 percent received grants, and 25 percent received loans. Students enrolled in first-professional programs were the most likely to receive aid (80 percent), followed by doctoral students (65 percent) and master's degree students (51 percent).

At each follow-up, B\&B students who enrolled in graduate school were asked if they ever received research or teaching assistantships, tuition waivers, employer assistance, grants, scholarships or fellowships, and loans. Table 9 presents information on highest graduate enrollment and various undergraduate characteristics (institution type, major, and GPA) as they relate to overall graduate school financing during the 10-year period. Loans were the most common source of financing for graduate school (45 percent), followed by grants, scholarships, or fellowships (23 percent), assistance from employers (19 percent), tuition waivers (10 percent), teaching assistantships ( 9 percent), and research assistantships ( 7 percent). Students whose highest graduate enrollment was in a doctoral degree program were the most likely, among all graduate students, to report receiving a research assistantship, teaching assistantship, tuition waiver, and grants or scholarships. Students enrolled in MBA programs (43 percent) were more likely to receive support for graduate education from an employer compared with students enrolled in other degree programs (5 to 18 percent). Similar to the findings reported by Choy and Moskovitz (1998), first-professional students (71 percent) were the most likely to receive loans to help pay for their graduate education, followed by doctoral students (63 percent) and master's degree students (35 to 40 percent).

Undergraduate major was related to graduate financing. Students who majored in biological sciences as undergraduates were generally more likely to receive grants, scholarships, or fellowships and more likely to take out loans than students who majored in other fields. Business and management and engineering majors were more likely than other majors to receive funding for their graduate education from an employer. Compared with other majors, students who majored in mathematics and other sciences were more likely to receive a teaching assistantship and tuition waiver.

Student's undergraduate performance, measured by GPA, was also related to graduate school financing. Students who earned a GPA of 3.5 or above were more likely to receive teaching assistantships, tuition waivers, and grants, scholarships, or fellowships. In short, 
Table 9. Percentage of graduate and first-professional students who received various types of financial aid, by student and institution characteristics: 2003-04

\begin{tabular}{|c|c|c|c|c|c|c|}
\hline $\begin{array}{l}\text { Student and institution } \\
\text { characteristics }\end{array}$ & $\begin{array}{r}\text { Research } \\
\text { assistant- } \\
\text { ships } \\
\end{array}$ & $\begin{array}{r}\text { Teaching } \\
\text { assistant- } \\
\text { ships } \\
\end{array}$ & $\begin{array}{l}\text { Tuition } \\
\text { waivers }\end{array}$ & $\begin{array}{l}\text { Employer } \\
\text { assistance }\end{array}$ & Grants $^{1}$ & Loans \\
\hline Total & 7.3 & 8.9 & 10.0 & 19.5 & 22.6 & 45.0 \\
\hline \multicolumn{7}{|l|}{ Highest graduate enrollment } \\
\hline MBA & 1.9 & 3.5 & 3.1 & 43.0 & 10.1 & 36.6 \\
\hline MEd & 1.2 & 2.4 & 8.9 & 16.0 & 14.3 & 35.5 \\
\hline Other master's & 5.5 & 7.7 & 7.8 & 17.9 & 21.6 & 40.5 \\
\hline First professional & 4.6 & 3.5 & 4.5 & 5.1 & 32.7 & 71.4 \\
\hline Doctorate & 37.3 & 40.4 & 36.3 & 9.1 & 51.2 & 63.1 \\
\hline \multicolumn{7}{|c|}{$\begin{array}{l}\text { Bachelor's degree-granting institution } \\
\text { Public 4-year }\end{array}$} \\
\hline Non-doctoral-granting & 4.3 & 6.1 & 6.5 & 22.1 & 15.2 & 40.3 \\
\hline Doctoral-granting & 8.8 & 9.7 & 12.1 & 18.2 & 24.1 & 46.7 \\
\hline \multicolumn{7}{|l|}{ Private not-for-profit 4-year } \\
\hline Non-doctoral-granting & 6.0 & 9.5 & 9.3 & 20.4 & 24.4 & 46.8 \\
\hline Doctoral-granting & 9.1 & 10.1 & 9.4 & 20.4 & 27.9 & 45.3 \\
\hline Other & 4.9 & 6.1 & 10.5 & 6.1 & 10.3 & 39.2 \\
\hline \multicolumn{7}{|l|}{ Baccalaureate degree major } \\
\hline Business and management & 1.8 & 4.0 & 6.5 & 33.3 & 12.1 & 33.8 \\
\hline Education & 3.1 & 4.8 & 11.2 & 15.9 & 18.9 & 34.7 \\
\hline Engineering & 12.5 & 13.7 & 6.2 & 29.3 & 21.3 & 31.8 \\
\hline Health professions & 2.0 & 6.2 & 6.1 & 24.0 & 28.5 & 33.7 \\
\hline Public affairs/social services & 4.0 & 2.3 & 2.4 & 18.3 & 24.9 & 55.2 \\
\hline Biological sciences & 15.9 & 15.3 & 15.5 & 9.7 & 36.5 & 65.9 \\
\hline Mathematics and other science & 19.8 & 23.2 & 20.0 & 23.2 & 25.4 & 43.8 \\
\hline Social science & 9.2 & 9.2 & 7.8 & 16.7 & 23.3 & 54.1 \\
\hline History & 10.6 & 3.2 & 13.2 & 8.7 & 22.2 & 53.2 \\
\hline Humanities & 6.1 & 12.6 & 12.1 & 13.9 & 31.5 & 47.0 \\
\hline Psychology & 4.7 & 10.4 & 8.5 & 14.0 & 21.2 & 56.4 \\
\hline Other & 7.3 & 5.6 & 9.5 & 15.6 & 20.3 & 53.6 \\
\hline \multicolumn{7}{|l|}{ Bachelor's degree GPA } \\
\hline Under 2.5 & 2.5 & 4.3 & 8.8 & 22.9 & 16.5 & 41.3 \\
\hline $2.5-2.99$ & 5.2 & 7.1 & 8.5 & 22.2 & 16.7 & 42.2 \\
\hline $3.0-3.49$ & 8.1 & 8.5 & 8.7 & 19.5 & 22.8 & 46.4 \\
\hline 3.5 or above & 9.8 & 12.6 & 13.0 & 15.9 & 28.6 & 46.4 \\
\hline
\end{tabular}

${ }^{1}$ Grants include scholarships and fellowships.

NOTE: Estimates include students from the 50 states, DC, and Puerto Rico. Detail may not sum to totals because of rounding. Standard error tables are available at http://nces.ed.gov/das/library/reports.asp.

SOURCE: U.S. Department of Education, National Center for Education Statistics, 1993/03 Baccalaureate and Beyond Longitudinal Study (B\&B:93/03). 
students who were high achievers as undergraduates were more likely to receive merit-based ${ }^{8}$ funding for graduate school.

In Dealing With Debt: 1992-93 Bachelor's Degree Recipients 10 Years Later, Choy and Li (2006) used data from the 1993/03 Baccalaureate and Beyond Longitudinal Study (B\&B:93/03) to further explore the financing of undergraduate, graduate, and first-professional education with this cohort. The results of that study show that 45 percent of bachelor's degree recipients who enrolled in graduate degree programs took out loans to help pay for that education and had borrowed an average of $\$ 33,200$ by 2003 (table 10). Similar to findings among this cohort that undergraduate borrowing does not affect enrollment in graduate school, undergraduate borrowing did not appear to affect borrowing for graduate education (Millett 2003; Choy 2000). Choy and $\mathrm{Li}$ (2006) reported that students who borrowed $\$ 5,000$ or more (55 to 58 percent) as undergraduates were more likely to borrow for graduate school than those who did not borrow at all (36 percent) or those who borrowed less than $\$ 5,000$ (46 percent). Given that master's degree programs are typically shorter than first-professional or doctoral degree programs (see "Time to Graduate Degree," below), students whose highest degree was a master's were the least likely of all graduate students to borrow to finance their education and they had borrowed the smallest amount.

\footnotetext{
${ }^{8}$ Merit-based aid is defined as aid in the form of tuition waivers, grants, scholarships, or fellowships. These forms of aid do not have to be repaid by students.
} 
Table 10. Among 1992-93 bachelor's degree recipients with graduate degree enrollment, percentage who borrowed for graduate education and, among borrowers, average amount borrowed for graduate education, by student and institution characteristics: 2003

\begin{tabular}{|c|c|c|}
\hline Student and institution characteristics & $\begin{array}{r}\text { Percent } \\
\text { who } \\
\text { borrowed } \\
\end{array}$ & $\begin{array}{r}\text { Average } \\
\text { amount }\end{array}$ \\
\hline Total & 44.8 & $\$ 33,200$ \\
\hline \multicolumn{3}{|l|}{ Type of degree-granting institution } \\
\hline Public 4-year & 44.4 & 31,200 \\
\hline Non-doctorate-granting & 40.0 & 25,000 \\
\hline Doctorate-granting & 46.5 & 33,900 \\
\hline Private not-for-profit 4-year & 45.9 & 36,600 \\
\hline Non-doctorate-granting & 46.1 & 31,300 \\
\hline Doctorate-granting & 45.7 & 42,300 \\
\hline Other & 41.3 & 31,900 \\
\hline \multicolumn{3}{|l|}{ Baccalaureate degree major } \\
\hline Business and management & 34.3 & 28,700 \\
\hline Education & 34.3 & 23,000 \\
\hline Engineering, mathematics, or computer science & 47.1 & 47,400 \\
\hline Humanities or social sciences & 52.8 & 32,800 \\
\hline Other & 47.4 & 28,100 \\
\hline \multicolumn{3}{|l|}{ Amount borrowed (undergraduate) } \\
\hline Did not borrow & 36.0 & 36,900 \\
\hline Less than $\$ 5,000$ & 45.7 & 30,300 \\
\hline$\$ 5,000-9,999$ & 56.3 & 29,200 \\
\hline$\$ 10,000-14,999$ & 54.7 & 28,700 \\
\hline$\$ 15,000$ or more & 58.4 & 35,100 \\
\hline \multicolumn{3}{|l|}{$\begin{array}{l}\text { Highest enrollment after bachelor's } \\
\text { degree by } 2003\end{array}$} \\
\hline Master's degree & 37.9 & 19,900 \\
\hline Doctoral degree & 63.1 & 43,700 \\
\hline First-professional degree & 71.8 & 69,200 \\
\hline \multicolumn{3}{|l|}{ Highest degree earned by 2003} \\
\hline Bachelor's degree & 32.3 & 23,300 \\
\hline Master's degree & 45.4 & 22,900 \\
\hline Doctoral degree & 64.3 & 44,100 \\
\hline First-professional degree & 78.8 & 75,500 \\
\hline
\end{tabular}

NOTE: Estimates include students from the 50 states, DC, and Puerto Rico. Standard error tables are available at http://nces.ed.gov/das/library/reports.asp.

SOURCE: Choy, S.P., and Li, X. (2006). Dealing With Debt 1992-93 Bachelor's Degree Recipients 10 Years Later, (NCES 2006-156), table 4. Data from U.S. Department of Education, National Center for Education Statistics, 1993/03 Baccalaureate and Beyond Longitudinal Study (B\&B:93/03). 


\section{THIS PAGE INTENTIONALLY LEFT BLANK}




\section{Characteristics of Enrollment}

\section{Enrollment Intensity and Continuity of Enrollment}

Whether or not students enroll part time or full time or remain continuously enrolled may have a relationship with their likelihood of success. Among 1992-93 bachelor's degree recipients who had enrolled in a graduate degree program by 2003, about one-half attended exclusively full time, and 52 percent took off at least one semester or term (table 11). Students who had majored in biological sciences as undergraduates were more likely to enroll full time than those with other majors (79 vs. 30 to 63 percent).

Students whose highest level of enrollment was in a doctoral or first-professional degree program were more likely to enroll full time than students enrolled in other graduate degree programs (73 and 84, respectively, vs. 29 to 50 percent). Furthermore, a greater proportion of students in first-professional degree programs were enrolled full time than students in doctoral degree programs (84 vs. 73 percent). Students in MEd programs typically were more likely to enroll part time.

Several demographic characteristics, such as students' gender, race/ethnicity, age, and undergraduate GPA and parents' education, were related to students' enrollment intensity in a graduate or first-professional degree program. For example, men were more likely than women to attend graduate school full time (54 vs. 46 percent), as were Asian/Pacific Islander students than students of other race/ethnicities (61 vs. 43 to 49 percent). In general, younger students were more likely than older students to attend graduate school full time: 56 percent of students age 22 or younger at the time they earned a bachelor's degree were full-time students, compared with 33 percent of students age 30 or older. Furthermore, students with higher undergraduate GPAs were more likely to enroll full time than their counterparts with lower GPAs, as were students whose parents held graduate degrees than students whose parents had less education. 
Table 11. Among 1992-93 bachelor's degree recipients who had enrolled in a graduate program by 2003, percentage distribution of enrollment intensity while enrolled and percentage taking time off, by student and institution characteristics

\begin{tabular}{|c|c|c|c|c|}
\hline \multirow[b]{2}{*}{ Student and institution characteristics } & \multicolumn{3}{|c|}{ Percentage distribution } & \multirow[b]{2}{*}{$\begin{array}{r}\text { Percent took off } \\
\text { at least one } \\
\text { semester or term } \\
\end{array}$} \\
\hline & $\begin{array}{r}\text { Exclusively } \\
\text { full-time }\end{array}$ & $\begin{array}{r}\text { Exclusively } \\
\text { part-time }\end{array}$ & $\begin{array}{r}\text { Mix of } \\
\text { full-time and } \\
\text { part-time }\end{array}$ & \\
\hline Total & 49.3 & 48.1 & 2.6 & 52.0 \\
\hline \multicolumn{5}{|l|}{ Highest graduate enrollment } \\
\hline MBA & 34.9 & 63.8 & 1.3 & 49.8 \\
\hline MEd & 28.9 & 67.8 & 3.3 & 63.8 \\
\hline Other master's & 49.6 & 48.0 & 2.4 & 51.0 \\
\hline First-professional & 83.8 & 15.2 & 1.0 & 35.6 \\
\hline Doctoral & 73.1 & 20.8 & 6.0 & 53.3 \\
\hline \multicolumn{5}{|l|}{ All graduate enrollment } \\
\hline \multicolumn{5}{|l|}{ Single enrollment } \\
\hline MBA & 37.6 & 60.8 & 1.6 & 41.9 \\
\hline MEd or post-master's certificate in education & 29.9 & 66.1 & 4.0 & 56.5 \\
\hline Other master's & 50.6 & 46.9 & 2.6 & 49.6 \\
\hline First-professional & 88.8 & 10.9 & 0.3 & 25.0 \\
\hline Doctoral & 87.5 & 2.1 & 10.4 & 36.4 \\
\hline \multicolumn{5}{|l|}{ Multiple enrollment } \\
\hline More than one master's & 28.6 & 70.4 & 1.0 & 78.6 \\
\hline Master's and doctoral & 61.1 & 32.2 & 6.7 & 65.2 \\
\hline First-professional and other & 78.3 & 20.2 & 1.5 & 51.7 \\
\hline \multicolumn{5}{|l|}{ Gender } \\
\hline Male & 54.0 & 44.0 & 2.0 & 50.5 \\
\hline Female & 45.5 & 51.3 & 3.1 & 53.1 \\
\hline \multicolumn{5}{|l|}{ Race/ethnicity ${ }^{2}$} \\
\hline White & 49.3 & 48.1 & 2.7 & 51.1 \\
\hline Black & 43.5 & 54.0 & 2.5 & 53.9 \\
\hline Hispanic & 44.0 & 53.0 & 3.0 & 53.8 \\
\hline Asian/Pacific Islander & 61.0 & 36.0 & 2.9 & 61.5 \\
\hline \multicolumn{5}{|l|}{ Age at bachelor's degree completion } \\
\hline 22 or younger & 56.4 & 41.1 & 2.6 & 49.1 \\
\hline $23-24$ & 44.8 & 51.6 & 3.6 & 53.5 \\
\hline $25-29$ & 36.9 & 60.3 & 2.9 & 58.3 \\
\hline 30 or older & 32.9 & 65.6 & 1.5 & 58.4 \\
\hline \multicolumn{5}{|l|}{ Highest education level by either parent } \\
\hline Less than high school & 43.9 & 53.6 & 2.4 & 63.3 \\
\hline High school or equivalency & 40.3 & 57.1 & 2.6 & 53.0 \\
\hline Some postsecondary & 46.5 & 51.1 & 2.3 & 47.6 \\
\hline Bachelor's degree & 51.4 & 45.8 & 2.8 & 54.0 \\
\hline Advanced degree & 57.5 & 39.9 & 2.6 & 49.0 \\
\hline
\end{tabular}

See notes at end of table. 
Table 11. Among 1992-93 bachelor's degree recipients who had enrolled in a graduate program by 2003, percentage distribution of enrollment intensity while enrolled and percentage taking time off, by student and institution characteristics—Continued

\begin{tabular}{|c|c|c|c|c|}
\hline \multirow[b]{2}{*}{ Student and institution characteristics } & \multicolumn{3}{|c|}{ Percentage distribution } & \multirow[b]{2}{*}{$\begin{array}{r}\text { Percent took off } \\
\text { at least one } \\
\text { semester or term } \\
\end{array}$} \\
\hline & $\begin{array}{r}\text { Exclusively } \\
\text { full-time }\end{array}$ & $\begin{array}{r}\text { Exclusively } \\
\text { part-time }\end{array}$ & $\begin{array}{r}\text { Mix of } \\
\text { full-time and } \\
\text { part-time }\end{array}$ & \\
\hline \multirow{2}{*}{\multicolumn{5}{|c|}{$\begin{array}{l}\text { Bachelor's degree-granting institution } \\
\text { Public 4-year }\end{array}$}} \\
\hline & & & & \\
\hline Non-doctoral-granting & 40.4 & 57.8 & 1.9 & 55.9 \\
\hline Doctoral-granting & 49.7 & 47.3 & 3.0 & 52.9 \\
\hline \multicolumn{5}{|l|}{ Private not-for-profit 4-year } \\
\hline Non-doctoral-granting & 46.3 & 51.7 & 2.0 & 50.0 \\
\hline Doctoral-granting & 59.7 & 38.0 & 2.3 & 48.7 \\
\hline Other & 64.3 & 26.6 & 9.1 & 42.0 \\
\hline \multicolumn{5}{|l|}{ Baccalaureate degree major } \\
\hline Business and management & 41.4 & 57.4 & 1.2 & 53.6 \\
\hline Education & 30.4 & 66.5 & 3.1 & 59.9 \\
\hline Engineering & 47.0 & 51.5 & 1.4 & 57.7 \\
\hline Health professions & 51.7 & 46.9 & 1.4 & 45.2 \\
\hline Public affairs/social services & 54.2 & 45.9 & \# & 49.6 \\
\hline Biological sciences & 78.8 & 19.7 & 1.5 & 40.4 \\
\hline Mathematics and other sciences & 60.0 & 39.1 & 0.9 & 53.8 \\
\hline Social science & 52.5 & 43.7 & 3.8 & 48.2 \\
\hline History & 63.2 & 32.4 & 4.4 & 52.7 \\
\hline Humanities & 53.9 & 42.8 & 3.3 & 47.8 \\
\hline Psychology & 54.2 & 41.1 & 4.7 & 56.5 \\
\hline Other & 46.9 & 48.6 & 4.6 & 51.3 \\
\hline \multicolumn{5}{|l|}{ Bachelor's degree GPA } \\
\hline Under 2.5 & 41.0 & 57.2 & 1.8 & 55.7 \\
\hline $2.5-2.99$ & 43.8 & 53.7 & 2.5 & 52.9 \\
\hline $3.0-3.49$ & 50.3 & 47.7 & 2.1 & 51.6 \\
\hline 3.5 or above & 55.4 & 41.3 & 3.3 & 50.7 \\
\hline
\end{tabular}

\# Rounds to zero.

${ }^{1}$ Does not include summer sessions.

${ }^{2}$ Black includes African American, Pacific Islander includes Native Hawaiian, and Hispanic includes Latino. Included in the totals but not shown separately are data for American Indian/Alaska Native respondents and those who identified themselves with another race not shown. Race categories exclude Hispanic origin unless specified.

NOTE: Estimates include students from the 50 states, DC, and Puerto Rico. Detail may not sum to totals because of rounding. Standard error tables are available at http://nces.ed.gov/das/library/reports.asp.

SOURCE: U.S. Department of Education, National Center for Education Statistics, 1993/03 Baccalaureate and Beyond Longitudinal Study (B\&B:93/03). 


\section{THIS PAGE INTENTIONALLY LEFT BLANK}




\section{Graduate Persistence and Attainment}

This section of the report includes a discussion on persistence and attainment among those students in the B\&B cohort who enrolled in graduate degree programs. Demographic characteristics and marital and parental status are looked at in relation to degree completion. The percentage of bachelor's degree recipients who are considering pursuing graduate studies is increasing. This section addresses whether students' educational expectations were realized. A large proportion of students with graduate expectations do not earn an advanced degree; the final part of this section discusses reasons why graduate students leave graduate school before completing a degree.

Among 1992-93 bachelor's degree recipients who had enrolled in a graduate degree program between 1993 and 2003, ${ }^{9} 62$ percent had earned at least one graduate degree by 2003. Looking at the highest degree earned, 47 percent had obtained a master's degree, 10 percent a first-professional degree, and 5 percent a doctoral degree (table 12). About 15 percent were still enrolled in a graduate degree program in 2003, and 23 percent were no longer enrolled and had not obtained a degree.

The rate at which students completed a graduate degree was related to the type of graduate program in which they had enrolled and the modal length of the program. The completion rate was highest among first-professional students ( 71 percent), followed by master's students (60 percent) and doctoral students (43 percent). Because doctoral degree students typically need more time to finish their program (see "Time to Graduate Degree," below), they were more likely than first-professional and master's degree students to be still enrolled in 2003 (28 vs. 11 and 13 percent, respectively). Master's degree students were more likely than first-professional and doctoral degree students to have left without completing a degree (27 vs. 15 and 11 percent, respectively).

More than half of the master's degrees awarded to the B\&B93 cohort were in education and business/management (table 13). Doctoral degree recipients tended to major in life and physical sciences ( 25 percent), engineering, mathematics, and computer science (14 percent), social and behavioral sciences (10 percent), and arts and humanities (8 percent).

\footnotetext{
9 These students are frequently referred to as "graduate students" in the subsequent discussion.
} 
Table 12. Among 1992-93 bachelor's degree recipients who had enrolled in a graduate degree program by 2003 , percentage distribution of attainment and enrollment status in 2003, by highest graduate enrollment

\begin{tabular}{|c|c|c|c|c|c|c|c|c|c|}
\hline \multirow[b]{2}{*}{$\begin{array}{l}\text { Highest graduate } \\
\text { enrollment }\end{array}$} & \multicolumn{4}{|c|}{ Attained } & \multicolumn{4}{|c|}{ Enrolled } & \multirow{2}{*}{$\begin{array}{r}\text { No } \\
\text { degree, } \\
\text { no longer } \\
\text { enrolled }\end{array}$} \\
\hline & Total & Master's ${ }^{1}$ & $\begin{array}{r}\text { First- } \\
\text { profes- } \\
\text { sional }\end{array}$ & Doctoral & Total & Master's & $\begin{array}{r}\text { First- } \\
\text { profes- } \\
\text { sional }\end{array}$ & Doctoral & \\
\hline Total & 61.9 & 47.1 & 10.0 & 4.8 & 14.7 & 10.5 & 1.3 & 2.9 & 23.4 \\
\hline Master's & 60.1 & 60.1 & $\dagger$ & $\dagger$ & 13.4 & 13.4 & $\dagger$ & $\dagger$ & 26.6 \\
\hline First-professional $1^{2}$ & 74.8 & 3.4 & 71.4 & $\dagger$ & 10.7 & 1.6 & 9.0 & $\dagger$ & 14.5 \\
\hline Doctoral $^{2}$ & 60.2 & 9.3 & 7.5 & 43.4 & 28.4 & 0.9 & 1.7 & 25.9 & 11.4 \\
\hline
\end{tabular}

$\dagger$ Not applicable.

${ }^{1}$ Students who have attained a master's degree are identified as having a master's degree if no higher degree was attained and the student was not enrolled in a doctoral or first-professional degree program in 2003.

2 Includes students who have earned a master's degree.

NOTE: Estimates include students from the 50 states, DC, and Puerto Rico. Detail may not sum to totals because of rounding. Standard error tables are available at http://nces.ed.gov/das/library/reports.asp.

SOURCE: U.S. Department of Education, National Center for Education Statistics, 1993/03 Baccalaureate and Beyond Longitudinal Study (B\&B:93/03).

\section{Demographic Characteristics}

Rates of graduate persistence and degree attainment were related to several demographic characteristics, such as students' gender, race/ethnicity, and age and their parents' education. For example, women were more likely than men to have earned a master's degree (49 vs. 44 percent) by 2003 , but men were more likely than women to have earned a first-professional (13 vs. 8 percent) or a doctoral degree (7 vs. 3 percent) (table 14).

Asian/Pacific Islander students were more likely than students from other racial/ethnic groups to have earned a first-professional degree ( 26 vs. 7 to 9 percent). Although Black students were more likely than White students to attend graduate school after receiving a bachelor's degree (see table 1), they were less likely to obtain a graduate degree (54 vs. 63 percent). However, Black students were more likely than White students to be still enrolled in 2003 (25 vs. 14 percent), particularly in a master's degree program (16 vs. 10 percent).

Students' age was also an important factor in their persistence in graduate programs and attainment of a degree. In general, the younger the students, the more likely they were to have earned a graduate degree, especially a first-professional or a doctoral degree. On the other hand, the older the students, the more likely they were to have left the program without earning a graduate degree. 


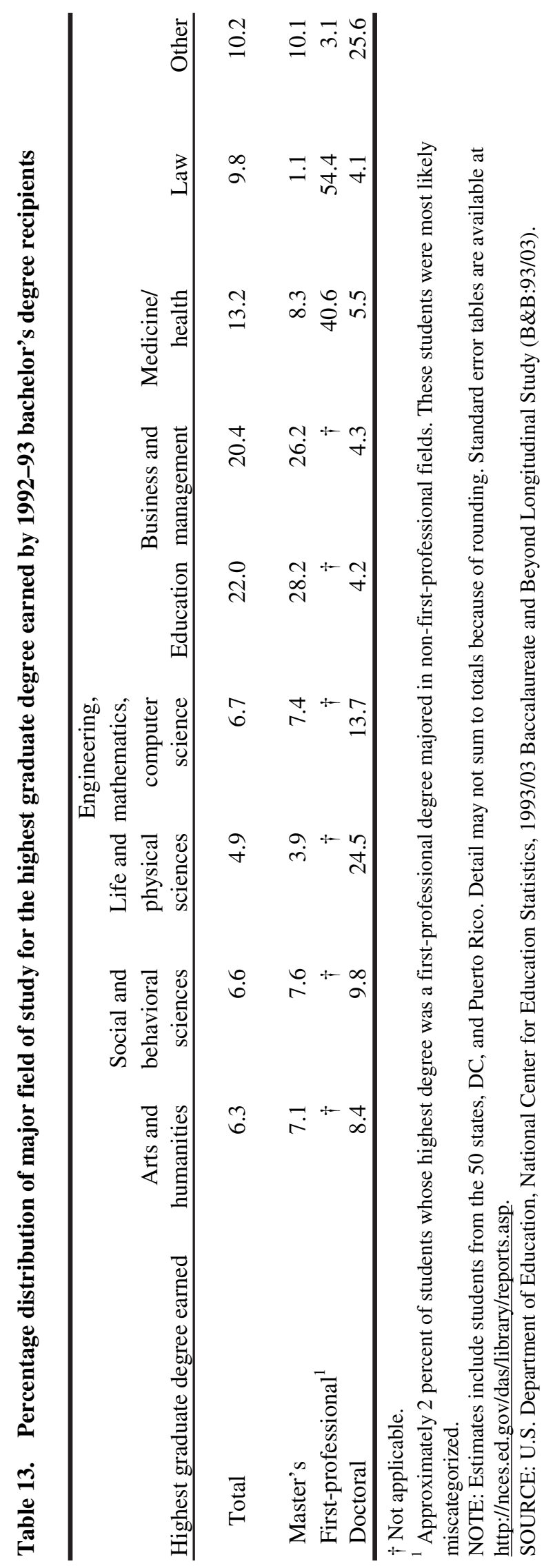


Table 14. Among 1992-93 bachelor's degree recipients who had enrolled in a graduate degree program by 2003 , percentage distribution of attainment and enrollment status in 2003, by selected student characteristics

\begin{tabular}{|c|c|c|c|c|c|c|c|c|c|}
\hline \multirow[b]{2}{*}{$\begin{array}{l}\text { Student } \\
\text { characteristics }\end{array}$} & \multicolumn{4}{|c|}{ Attained } & \multicolumn{4}{|c|}{ Enrolled } & \multirow{2}{*}{$\begin{array}{r}\text { No } \\
\text { degree, } \\
\text { no longer } \\
\text { enrolled }\end{array}$} \\
\hline & Total & Master's ${ }^{1}$ & $\begin{array}{r}\text { First- } \\
\text { profes- } \\
\text { sional } \\
\end{array}$ & Doctoral & Total & Master's & $\begin{array}{r}\text { First- } \\
\text { profes- } \\
\text { sional } \\
\end{array}$ & Doctoral & \\
\hline Total & 61.9 & 47.1 & 10.0 & 4.8 & 14.7 & 10.5 & 1.3 & 2.9 & 23.4 \\
\hline \multicolumn{10}{|l|}{ Gender } \\
\hline Male & 63.9 & 44.3 & 12.7 & 6.9 & 14.6 & 9.9 & 1.7 & 3.0 & 21.5 \\
\hline Female & 60.2 & 49.4 & 7.7 & 3.2 & 14.8 & 11.1 & 1.0 & 2.7 & 25.0 \\
\hline \multicolumn{10}{|l|}{ Race/ethnicity $^{2}$} \\
\hline White & 62.6 & 48.8 & 9.3 & 4.5 & 13.7 & 9.9 & 1.1 & 2.7 & 23.7 \\
\hline Black & 53.8 & 42.1 & 6.6 & 5.1 & 24.7 & 15.7 & 3.8 & 5.2 & 21.5 \\
\hline Hispanic & 55.9 & 39.2 & 8.3 & 8.4 & 19.3 & 16.3 & 1.0 & 2.0 & 24.8 \\
\hline Asian/Pacific Islander & 64.8 & 35.2 & 26.4 & 3.2 & 12.8 & 8.4 & 2.5 & 2.0 & 22.4 \\
\hline \multicolumn{10}{|c|}{$\begin{array}{l}\text { Age at bachelor's degree } \\
\text { completion }\end{array}$} \\
\hline 22 or younger & 67.2 & 47.3 & 13.7 & 6.3 & 12.6 & 8.4 & 0.9 & 3.3 & 20.2 \\
\hline $23-24$ & 54.2 & 43.9 & 6.7 & 3.6 & 18.7 & 13.2 & 2.5 & 3.0 & 27.1 \\
\hline $25-29$ & 52.2 & 46.9 & 2.6 & 2.7 & 18.7 & 14.9 & 2.7 & 1.1 & 29.1 \\
\hline 30 or older & 55.7 & 50.2 & 3.6 & 1.8 & 15.3 & 12.9 & 0.6 & 1.9 & 29.0 \\
\hline \multicolumn{10}{|l|}{$\begin{array}{l}\text { Highest education level } \\
\text { by either parent }\end{array}$} \\
\hline Less than high school & 52.5 & 42.9 & 4.7 & 5.0 & 19.9 & 15.8 & 1.0 & 3.1 & 27.7 \\
\hline $\begin{array}{l}\text { High school or } \\
\text { equivalency }\end{array}$ & 55.7 & 46.7 & 6.5 & 2.5 & 16.4 & 13.6 & 1.4 & 1.5 & 27.9 \\
\hline Some postsecondary & 60.9 & 50.2 & 8.0 & 2.6 & 15.2 & 11.6 & 2.0 & 1.6 & 23.9 \\
\hline Bachelor's degree & 61.8 & 45.0 & 10.6 & 6.2 & 16.5 & 11.3 & 1.2 & 4.0 & 21.7 \\
\hline Advanced degree & 67.4 & 47.1 & 13.7 & 6.6 & 11.6 & 6.9 & 1.1 & 3.7 & 21.0 \\
\hline
\end{tabular}

${ }^{1}$ Students who have attained a master's degree are identified as having a master's degree if no higher degree was attained and the student was not enrolled in a doctoral or first-professional degree program in 2003.

${ }^{2}$ Black includes African American, Pacific Islander includes Native Hawaiian, and Hispanic includes Latino. Included in the totals but not shown separately are data for American Indian/Alaska Native respondents and those who identified themselves with another race not shown. Race categories exclude Hispanic origin unless specified.

NOTE: Estimates include students from the 50 states, DC, and Puerto Rico. Detail may not sum to totals because of rounding. Standard error tables are available at http://nces.ed.gov/das/library/reports.asp.

SOURCE: U.S. Department of Education, National Center for Education Statistics, 1993/03 Baccalaureate and Beyond Longitudinal Study (B\&B:93/03).

The likelihood of graduate students earning a graduate degree was also related to their parents' highest education level, increasing from 52 percent among those whose parents had less than a high school education to 67 percent among those whose parents had a graduate degree. In addition, students whose parents had no more than a high school education were more likely than 
their peers whose parents had a bachelor's or higher degree to have left without earning a graduate degree.

\section{Marital and Parental Status}

Married students or students with dependent children typically have more family responsibilities, which may impinge upon the time available to study. This is reflected in their rates of degree persistence and completion: students who were single or had no children before graduate enrollment were more likely to have earned a graduate degree by 2003 , particularly a first-professional or a doctoral degree, whereas students who were married or had one or more children before graduate enrollment were more likely to be still enrolled (table 15).

Marriage was an important factor in students' likelihood of enrolling in a graduate degree program regardless of gender: married men and women were less likely than their single counterparts to have attained a graduate degree (men: 58 vs. 66 percent, women: 51 vs. 66 percent), especially a first-professional (men: 6 vs. 16 percent, women: 3 vs. 11 percent) or a doctoral degree (men: 4 vs. 8 percent, women: 2 vs. 4 percent). Thirty-two percent of men who were divorced, separated, or widowed before enrolling in a graduate program were still enrolled in that program in 2003, compared with 13 percent of single men. Among women, 23 percent of those who were married were still enrolled, compared with 10 percent of single women.

Parenthood seemed to be a stronger negative factor for women than for men with regard to their attainment of a graduate degree. For example, among men, having a child before enrollment was related negatively only to their likelihood of attaining a first-professional degree. Although it appears that men who have no children were more likely to earn a graduate degree than men with children, no statistical difference was detected. Among women, having a child was related negatively to overall graduate degree attainment, especially for completing a first-professional or doctoral degree. Because women with children needed more time than women without children to finish a degree, as described below, they were more likely to be still enrolled in 2003 (26 vs. 13 percent). The same pattern was observed for men, but no statistical difference was detected (21 vs. 14 percent).

\section{Educational Expectations}

Graduates' degree attainment did not align with their educational expectations at the time that they had completed a bachelor's degree. This was especially true among those with doctoral degree aspirations: 11 percent of graduate students who expected to earn a doctoral degree at the time of bachelor's degree completion (around 1993) had done so by 2003, and just 5 percent 
Table 15. Among 1992-93 bachelor's degree recipients who enrolled in a graduate degree program by 2003, percentage distribution of attainment and enrollment status in 2003, by gender and marital and parental status 1 year before graduate enrollment

\begin{tabular}{|c|c|c|c|c|c|c|c|c|c|}
\hline \multirow[b]{2}{*}{$\begin{array}{l}\text { Gender and marital } \\
\text { and parental status }\end{array}$} & \multicolumn{4}{|c|}{ Attained } & \multicolumn{4}{|c|}{ Enrolled } & \multirow[b]{2}{*}{$\begin{array}{r}\text { No } \\
\text { degree, } \\
\text { no longer } \\
\text { enrolled } \\
\end{array}$} \\
\hline & Total & Master's ${ }^{1}$ & $\begin{array}{r}\text { First- } \\
\text { profes- } \\
\text { sional } \\
\end{array}$ & Doctoral & Total & Master's & $\begin{array}{r}\text { First- } \\
\text { profes- } \\
\text { sional } \\
\end{array}$ & Doctoral & \\
\hline Total & 61.9 & 47.1 & 10.0 & 4.8 & 14.7 & 10.5 & 1.3 & 2.9 & 23.4 \\
\hline \multicolumn{10}{|l|}{$\begin{array}{l}\text { Marital status year before } \\
\text { graduate enrollment }\end{array}$} \\
\hline Single & 66.0 & 46.8 & 13.2 & 6.0 & 11.5 & 6.8 & 1.5 & 3.2 & 22.5 \\
\hline Married/cohabit as married & 53.7 & 46.8 & 4.2 & 2.7 & 20.8 & 17.6 & 0.9 & 2.2 & 25.5 \\
\hline Divorced/separated/widowed & 53.1 & 50.4 & 1.8 & 0.8 & 23.9 & 17.9 & 1.9 & 4.1 & 23.1 \\
\hline \multicolumn{10}{|c|}{$\begin{array}{l}\text { Number of dependent children year } \\
\text { before graduate enrollment }\end{array}$} \\
\hline None & 63.9 & 47.5 & 11.1 & 5.3 & 13.3 & 8.9 & 1.4 & 3.0 & 22.9 \\
\hline One or more & 49.2 & 43.7 & 3.9 & 1.6 & 24.1 & 20.3 & 1.2 & 2.6 & 26.7 \\
\hline \multicolumn{10}{|l|}{ Male } \\
\hline Total & 63.9 & 44.3 & 12.7 & 6.9 & 14.6 & 9.9 & 1.7 & 3.0 & 21.5 \\
\hline \multicolumn{10}{|l|}{$\begin{array}{l}\text { Marital status year before } \\
\text { graduate enrollment }\end{array}$} \\
\hline Single & 66.4 & 42.3 & 16.1 & 8.1 & 12.8 & 8.0 & 2.1 & 2.7 & 20.8 \\
\hline Married/cohabit as married & 58.3 & 48.0 & 6.0 & 4.3 & 17.6 & 13.9 & 0.6 & 3.1 & 24.1 \\
\hline Divorced/separated/widowed & 58.1 & 52.4 & 5.7 & \# & 32.4 & 17.2 & 3.5 & 11.7 & 9.4 \\
\hline \multicolumn{10}{|c|}{$\begin{array}{l}\text { Number of dependent children year } \\
\text { before graduate enrollment }\end{array}$} \\
\hline None & 65.1 & 44.1 & 13.7 & 7.3 & 13.9 & 9.2 & 1.9 & 2.8 & 21.0 \\
\hline One or more & 55.8 & 45.3 & 6.9 & 3.6 & 20.9 & 15.5 & \# & 5.4 & 23.3 \\
\hline \multicolumn{10}{|l|}{ Female } \\
\hline Total & 60.2 & 49.4 & 7.7 & 3.2 & 14.8 & 11.1 & 1.0 & 2.7 & 25.0 \\
\hline \multicolumn{10}{|l|}{$\begin{array}{l}\text { Marital status year before } \\
\text { graduate enrollment }\end{array}$} \\
\hline Single & 65.6 & 50.7 & 10.8 & 4.1 & 10.4 & 5.8 & 1.0 & 3.6 & 24.1 \\
\hline Married/cohabit as married & 50.6 & 46.0 & 3.0 & 1.6 & 22.9 & 20.1 & 1.2 & 1.6 & 26.5 \\
\hline Divorced/separated/widowed & 50.8 & 49.5 & \# & 1.2 & 20.0 & 18.2 & 1.2 & 0.6 & 29.3 \\
\hline \multicolumn{10}{|c|}{$\begin{array}{l}\text { Number of dependent children year } \\
\text { before graduate enrollment }\end{array}$} \\
\hline None & 62.9 & 50.5 & 8.8 & 3.7 & 12.7 & 8.7 & 0.9 & 3.1 & 24.4 \\
\hline One or more & 45.9 & 42.9 & 2.4 & 0.6 & 25.7 & 22.8 & 1.8 & 1.2 & 28.4 \\
\hline
\end{tabular}

\# Rounds to zero.

${ }^{1}$ Students who have attained a master's degree are identified as having a master's degree if no higher degree was attained and the student was not enrolled in a doctoral or first-professional degree program in 2003.

NOTE: Estimates include students from the 50 states, DC, and Puerto Rico. Detail may not sum to totals because of rounding. Standard error tables are available at http://nces.ed.gov/das/library/reports.asp.

SOURCE: U.S. Department of Education, National Center for Education Statistics, 1993/03 Baccalaureate and Beyond Longitudinal Study (B\&B:93/03). 
were still enrolled in a doctoral program in 2003 (table 16). Some with doctoral degree aspirations had earned another graduate degree: 41 percent had earned a master's degree, and another 10 percent had earned a first-professional degree. About 25 percent had left without completing any graduate degree.

Table 16. Among 1992-93 bachelor's degree recipients who had enrolled in a graduate degree program by 2003 , percentage distribution of attainment and enrollment status in 2003 , by educational expectations at bachelor's degree completion

\begin{tabular}{|c|c|c|c|c|c|c|c|c|c|}
\hline \multirow[b]{2}{*}{$\begin{array}{l}\text { Educational expectations } \\
\text { at bachelor's degree } \\
\text { completion }\end{array}$} & \multicolumn{4}{|c|}{ Attained } & \multicolumn{4}{|c|}{ Enrolled } & \multirow{2}{*}{$\begin{array}{r}\text { No } \\
\text { degree, } \\
\text { no longer } \\
\text { enrolled }\end{array}$} \\
\hline & Total & Master's $^{1}$ & $\begin{array}{r}\text { First- } \\
\text { profes- } \\
\text { sional }\end{array}$ & Doctoral & Total & Master's & $\begin{array}{l}\text { First- } \\
\text { profes- } \\
\text { sional }\end{array}$ & Doctoral & \\
\hline Total & 61.9 & 47.1 & 10.0 & 4.8 & 14.7 & 10.5 & 1.3 & 2.9 & 23.4 \\
\hline Bachelor's degree or less & 53.2 & 44.7 & 6.2 & 2.3 & 23.2 & 15.8 & 4.6 & 2.7 & 23.7 \\
\hline Master's degree & 60.5 & 57.1 & 2.5 & 0.8 & 15.5 & 12.7 & 0.9 & 2.0 & 24.0 \\
\hline First-professional degree & 74.3 & 19.0 & 46.4 & 8.9 & 9.1 & 4.8 & 3.0 & 1.3 & 16.7 \\
\hline Doctoral degree & 61.9 & 41.2 & 9.9 & 10.8 & 13.5 & 7.9 & 0.7 & 5.0 & 24.6 \\
\hline
\end{tabular}

${ }^{1}$ Students who have attained a master's degree are identified as having a master's degree if no higher degree was attained and the student was not enrolled in a doctoral or first-professional degree program in 2003.

NOTE: Estimates include students from the 50 states, DC, and Puerto Rico. Detail may not sum to totals because of rounding. Standard error tables are available at http://nces.ed.gov/das/library/reports.asp.

SOURCE: U.S. Department of Education, National Center for Education Statistics, 1993/03 Baccalaureate and Beyond Longitudinal Study (B\&B:93/03).

Compared with those with doctoral degree expectations, those with first-professional or master's degree expectations were more successful in achieving their goals: about 46 percent of graduate students with first-professional degree expectations and 57 percent of those with master's degree expectations had earned their expected degree by 2003. Overall, graduate students with first-professional degree expectations were more likely than those with master's or doctoral degree expectations to have attained a graduate degree (74 vs. 60 and 62 percent, respectively) and less likely to leave without attaining one (17 vs. 24 and 25 percent, respectively).

As noted in table 4, about 17 percent of bachelor's degree recipients with expectations no greater than a baccalaureate degree enrolled in a graduate degree program. Among these students, about one-half (53 percent) had earned a graduate degree by 2003 , including 45 percent of a master's degree, 6 percent of a first-professional degree, and 2 percent of a doctoral degree (table 16). About 23 percent were still enrolled in a graduate degree program in 2003. 


\section{Enrollment Characteristics}

As expected, graduate persistence and attainment were related to the time taken between bachelor's degree completion and first enrollment in a graduate program. The shorter this time, the more likely students were to have earned a graduate degree by 2003 (table 17). On the other hand, the longer students delayed graduate enrollment, the more likely they were to be still enrolled.

Other characteristics, such as enrollment continuity and intensity, are related to graduates' rates of persistence and attainment. Graduate students who enrolled continuously and full time were more likely than those who took time off or enrolled part time to have earned a graduate degree and less likely to have left without a degree. Part-time graduate students typically need more time than their full-time counterparts to finish their degree and therefore were more likely to be still enrolled in 2003 (19 vs. 9 percent).

Looking at major fields of study for the highest level of graduate enrollment, 82 percent of law majors had attained a graduate degree (mostly a professional law degree) by 2003, a higher percentage than for those with all other majors. Following law majors were health professions majors (70 percent had earned a graduate degree by 2003) and life and physical science majors (67 percent), but this latter percentage was not measurably different from that for most other majors. ${ }^{10}$

\section{Reasons for Leaving}

Considerable attention has been paid to graduate attrition (Bowen and Rudenstine 1992; National Academy of Sciences 1996), but little research has actually focused on student-reported reasons for leaving graduate school. During the B\&B:93/03 follow-up interview, students who indicated they had entered a graduate degree program between 1997 and 2003 and had left without completing a degree were asked to report the reasons they left. One of the most common reasons reported by students was a change in family status (30 vs. 1 to 16 percent) (figure 1) which supports earlier findings in this report suggesting that single students and students who had no children when they received a bachelor's degree were, in fact, more likely to persist and complete a graduate degree (table 15). According to student reports, other common reasons for leaving their graduate program without completing were related to their dissatisfaction with the program (16 percent), conflicts with their job and the military (17 percent) and needing to work (14 percent).

\footnotetext{
${ }^{10}$ It was significantly different from arts and humanities and law majors.
} 
Table 17. Among 1992-93 bachelor's degree recipients who had enrolled in a graduate degree program by 2003 , percentage distribution of attainment and enrollment status in 2003 , by graduate enrollment characteristics

\begin{tabular}{|c|c|c|c|c|c|c|c|c|c|}
\hline \multirow[b]{2}{*}{$\begin{array}{l}\text { Graduate enrollment } \\
\text { characteristics }\end{array}$} & \multicolumn{4}{|c|}{ Attained } & \multicolumn{4}{|c|}{ Enrolled } & \multirow{2}{*}{$\begin{array}{r}\text { No } \\
\text { degree, } \\
\text { no longer } \\
\text { enrolled }\end{array}$} \\
\hline & Total & Master's ${ }^{1}$ & $\begin{array}{r}\text { First- } \\
\text { profes- } \\
\text { sional } \\
\end{array}$ & Doctoral & Total & Master's & $\begin{array}{r}\text { First- } \\
\text { profes- } \\
\text { sional } \\
\end{array}$ & Doctoral & \\
\hline Total & 61.9 & 47.1 & 10.0 & 4.8 & 14.7 & 10.5 & 1.3 & 2.9 & 23.4 \\
\hline \multicolumn{10}{|c|}{$\begin{array}{l}\text { Time between bachelor's completion } \\
\text { and first graduate enrollment }\end{array}$} \\
\hline 1 year or less & 68.6 & 44.2 & 14.9 & 9.6 & 7.1 & 3.0 & 0.8 & 3.3 & 24.3 \\
\hline More than 1 to 3 years & 63.4 & 49.0 & 11.2 & 3.1 & 9.3 & 5.2 & 0.8 & 3.3 & 27.4 \\
\hline More than 3 to 5 years & 64.8 & 56.8 & 6.0 & 2.0 & 10.2 & 6.8 & 0.8 & 2.7 & 25.0 \\
\hline More than 5 years & 44.9 & 41.6 & 2.8 & 0.6 & 40.4 & 35.0 & 3.6 & 1.8 & 14.7 \\
\hline \multicolumn{10}{|c|}{ Continuity of graduate enrollment } \\
\hline Continuously enrolled & 67.0 & 47.1 & 14.7 & 5.3 & 15.6 & 11.4 & 1.9 & 2.2 & 17.4 \\
\hline $\begin{array}{l}\text { Took off at least one } \\
\text { semester or term }\end{array}$ & 57.9 & 47.8 & 5.7 & 4.4 & 13.8 & 9.6 & 0.8 & 3.5 & 28.3 \\
\hline \multicolumn{10}{|l|}{ Enrollment intensity } \\
\hline Exclusively full-time & 74.0 & 47.4 & 18.6 & 8.0 & 9.4 & 4.8 & 1.8 & 2.8 & 16.6 \\
\hline Exclusively part-time & 50.7 & 47.7 & 1.5 & 1.5 & 19.0 & 16.0 & 0.8 & 2.2 & 30.3 \\
\hline $\begin{array}{l}\text { Mix of full-time and } \\
\text { part-time }\end{array}$ & 51.6 & 42.9 & 3.4 & 5.3 & 39.5 & 20.8 & 1.3 & 17.4 & 8.9 \\
\hline \multicolumn{10}{|c|}{ Major for highest graduate enrollment } \\
\hline Arts and humanities & 53.4 & 45.5 & 2.0 & 5.9 & 15.2 & 10.2 & 0.3 & 4.7 & 31.4 \\
\hline $\begin{array}{l}\text { Social and behavioral } \\
\text { sciences }\end{array}$ & 57.3 & 50.9 & \# & 6.4 & 20.1 & 10.1 & \# & 10.0 & 22.7 \\
\hline Life and physical sciences & 67.0 & 38.7 & 1.0 & 27.4 & 6.6 & 3.7 & 0.6 & 2.2 & 26.4 \\
\hline $\begin{array}{l}\text { Engineering, mathematics, } \\
\text { computer science }\end{array}$ & 56.9 & 47.3 & 0.4 & 9.3 & 11.8 & 6.8 & 0.2 & 4.8 & 31.3 \\
\hline Education & 59.2 & 58.1 & 0.3 & 0.9 & 15.1 & 12.7 & \# & 2.4 & 25.7 \\
\hline Business and management & 60.4 & 59.4 & \# & 1.0 & 18.0 & 17.0 & \# & 1.0 & 21.6 \\
\hline Medicine/health & 69.5 & 34.0 & 33.5 & 2.0 & 11.5 & 4.4 & 6.3 & 0.8 & 18.9 \\
\hline Law & 82.5 & 8.3 & 72.0 & 2.2 & 5.3 & 2.0 & 3.3 & \# & 12.3 \\
\hline Other & 59.4 & 45.2 & 2.3 & 11.9 & 18.9 & 11.5 & 2.7 & 4.7 & 21.7 \\
\hline
\end{tabular}

\# Rounds to zero.

${ }^{1}$ Students who have attained a master's degree are identified as having a master's degree if no higher degree was attained and the student was not enrolled in a doctoral or first-professional degree program in 2003.

NOTE: Estimates include students from the 50 states, DC, and Puerto Rico. Detail may not sum to totals because of rounding. Standard error tables are available at http://nces.ed.gov/das/library/reports.asp.

SOURCE: U.S. Department of Education, National Center for Education Statistics, 1993/03 Baccalaureate and Beyond Longitudinal Study (B\&B:93/03). 
Figure 1. Among 1992-93 bachelor's degree recipients who enrolled in a graduate degree program between 1997 and 2003, percentage who left for various reasons

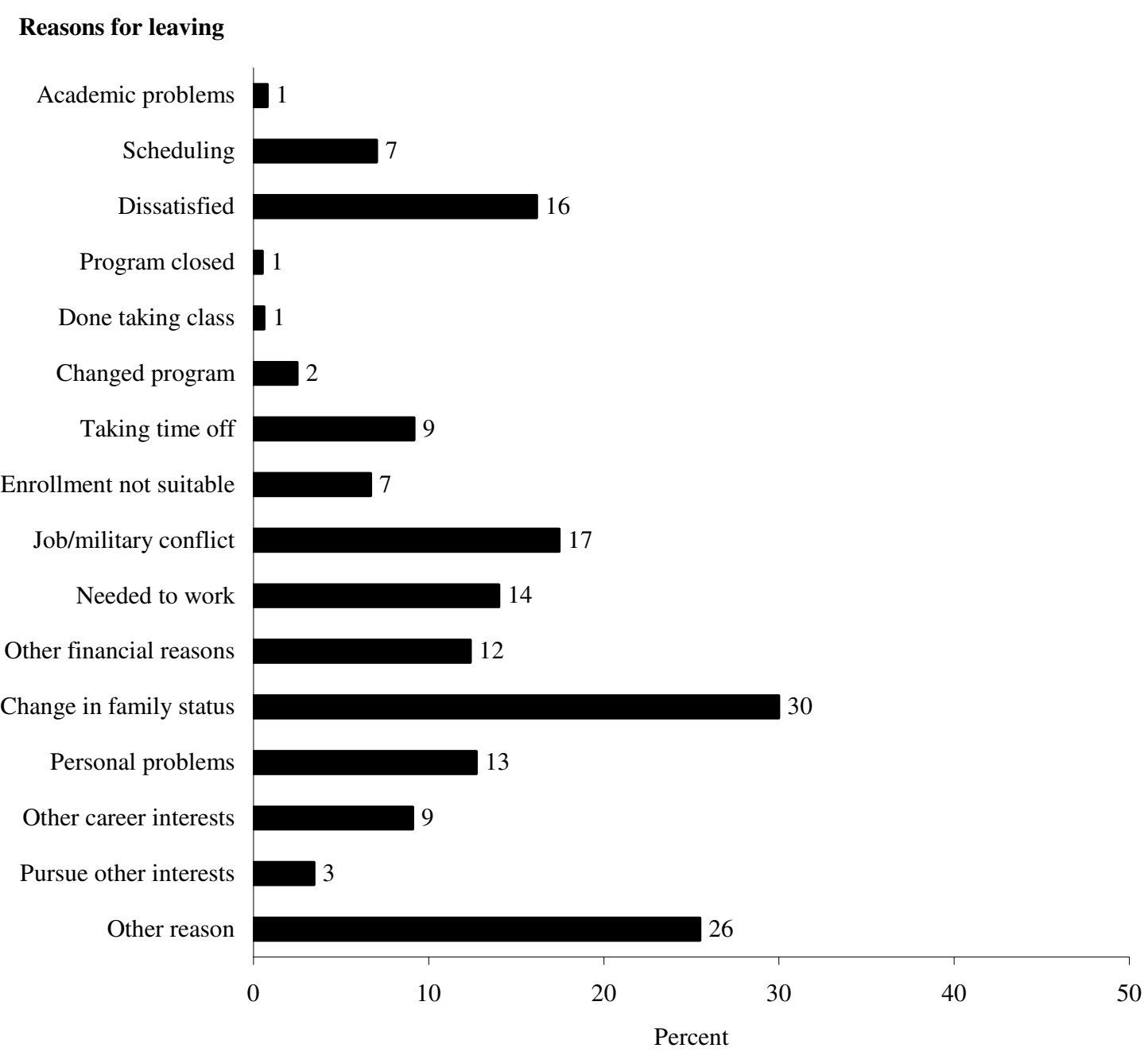

NOTE: Estimates include students from the 50 states, DC, and Puerto Rico. Standard error tables are available at http://nces.ed.gov/das/library/reports.asp.

SOURCE: U.S. Department of Education, National Center for Education Statistics, 1993/03 Baccalaureate and Beyond Longitudinal Study (B\&B:93/03). 


\section{Time to Graduate Degree}

The amount of time students took to complete a graduate degree depended on the type of degree they earned. Students who completed a graduate degree within the 10-year study period took an average of 3 years to complete a master's degree, 4 years to complete a first-professional degree, and 6 years to complete a doctoral degree (figure 2). ${ }^{11}$

Figure 2. Among 1992-93 bachelor's degree recipients who had earned a graduate degree by 2003, average number of years between first graduate enrollment and attainment of highest graduate degree, by highest graduate degree earned

Number of years

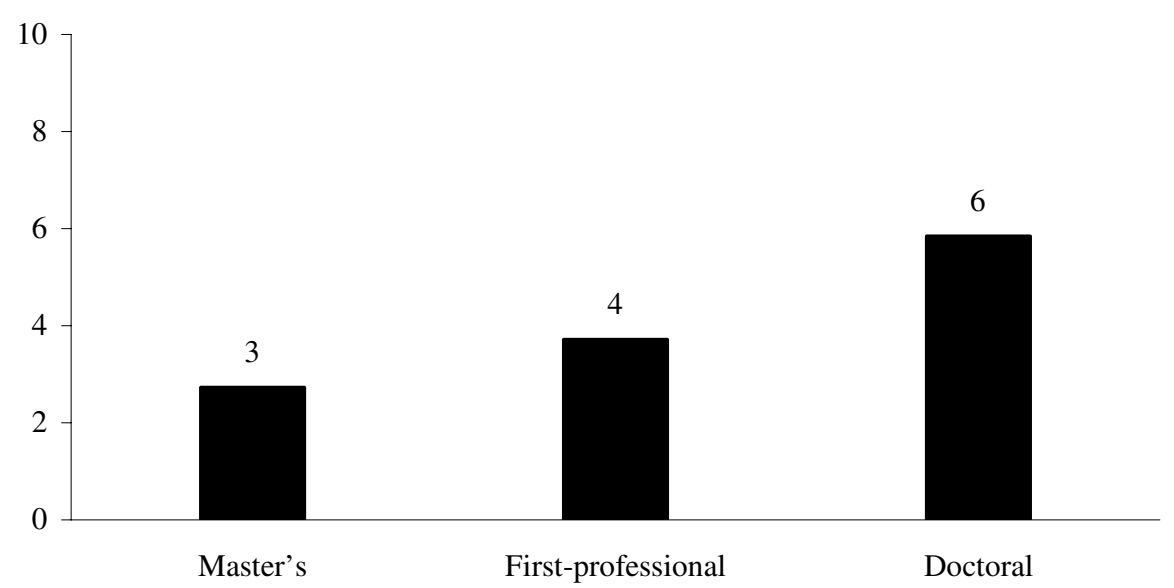

Highest graduate degree earned

NOTE: Estimates include students from the 50 states, DC, and Puerto Rico. Standard error tables are available at http://nces.ed.gov/das/library/reports.asp.

SOURCE: U.S. Department of Education, National Center for Education Statistics, 1993/03 Baccalaureate and Beyond Longitudinal Study (B\&B:93/03).

11 The time to graduate degree may be underestimated because some students had not yet graduated and were still enrolled in 2003. 


\section{Master's Degree}

A majority of master's degree recipients (70 percent) finished that degree within 3 years, 22 percent took 3-5 years, and 8 percent took more than 5 years (table 18a). The time it took to complete a master's degree was related to several student characteristics. For example, Hispanic students took longer than Asian/Pacific Islander, Black, and White students to finish a master's degree. Older students (age 30 or older) took longer than younger students (age 22 or younger) to finish. Students whose parents had only a high school education were more likely to take 5 years or longer to complete a master's degree than those whose parents had a graduate degree. However, no gender differences were found in terms of the time it took to complete a master's degree.

Graduate students majoring in social and behavioral sciences were more likely than those majoring in life and physical sciences, business and management, education, and arts and humanities to finish a master's degree within 3 years (86 percent vs. 53 to 70 percent). Graduate students majoring in medicine and health ( 85 percent) were also more likely than those majoring in business and management, education, and arts and humanities to finish a master's degree within 3 years (53 to 67 percent). Those who majored in arts and humanities were the least likely to complete a master's degree within that time frame (53 percent).

In general, divorce, separation, or widowhood prolonged time to a master's degree: students who were divorced, separated, or widowed before enrolling in a master's degree program took more time to finish a master's degree than those who were either single or married (table 18b). However, this relationship was observed only for women. Having one or more children was also related to taking a longer time to obtain a master's degree. Again, this relationship was observed only for women.

Late starters in a master's degree program seemed to finish that degree faster: those who had delayed graduate enrollment for more than 5 years after receiving a bachelor's degree took about 2 years to complete a master's degree, whereas those who had enrolled immediately took about 3 years to do so (table 18c). As expected, disrupted and part-time enrollment increased time to master's degree: students who took off at least one semester or enrolled part time took longer to finish than those enrolled continuously or full time or a mix of full and part time. 
Table 18a. Among 1992-93 bachelor's degree recipients who had earned a master's degree by 2003, average number of years and percentage distribution of time from first graduate enrollment to completion of master's degree, by selected student characteristics

\begin{tabular}{|c|c|c|c|c|}
\hline \multirow[b]{2}{*}{ Student characteristics } & \multirow{2}{*}{$\begin{array}{r}\text { Average } \\
\text { number of } \\
\text { years } \\
\end{array}$} & \multicolumn{3}{|c|}{ Percentage distribution } \\
\hline & & $\begin{array}{r}\text { years } \\
\text { or less } \\
\end{array}$ & $\begin{array}{r}\text { More than } 3 \\
\text { to } 5 \text { years } \\
\end{array}$ & $\begin{array}{r}\text { More than } \\
5 \text { years }\end{array}$ \\
\hline Total & 2.7 & 69.9 & 21.7 & 8.5 \\
\hline \multicolumn{5}{|l|}{ Gender } \\
\hline Male & 2.7 & 72.1 & 19.1 & 8.8 \\
\hline Female & 2.8 & 68.3 & 23.5 & 8.3 \\
\hline \multicolumn{5}{|l|}{ Race/ethnicity $^{1}$} \\
\hline White & 2.7 & 69.8 & 22.4 & 7.8 \\
\hline Black & 2.8 & 75.4 & 11.1 & 13.5 \\
\hline Hispanic & 3.4 & 51.3 & 33.3 & 15.3 \\
\hline Asian/Pacific Islander & 2.3 & 87.4 & 5.4 & 7.2 \\
\hline \multicolumn{5}{|c|}{ Age at bachelor's degree completion } \\
\hline 22 or younger & 2.7 & 72.6 & 20.2 & 7.2 \\
\hline $23-24$ & 2.6 & 76.0 & 16.3 & 7.8 \\
\hline $25-29$ & 3.4 & 54.0 & 30.3 & 15.7 \\
\hline 30 or older & 3.0 & 59.5 & 29.6 & 11.0 \\
\hline \multicolumn{5}{|c|}{ Highest education level by either parent } \\
\hline Less than high school & 2.4 & 77.2 & 22.8 & \# \\
\hline High school or equivalency & 2.9 & 67.8 & 19.8 & 12.4 \\
\hline Some postsecondary & 2.7 & 69.7 & 22.0 & 8.3 \\
\hline Bachelor's degree & 2.8 & 68.8 & 22.8 & 8.5 \\
\hline Advanced degree & 2.5 & 74.5 & 20.9 & 4.6 \\
\hline \multicolumn{5}{|l|}{ Major for master's degree } \\
\hline Arts and humanities & 3.1 & 52.5 & 39.2 & 8.3 \\
\hline Social and behavioral sciences & 2.3 & 85.5 & 11.2 & 3.2 \\
\hline Life and physical sciences & 2.7 & 70.0 & 24.4 & 5.6 \\
\hline $\begin{array}{l}\text { Engineering, mathematics, } \\
\text { computer science }\end{array}$ & 2.6 & 73.4 & 15.2 & 11.4 \\
\hline Education & 2.8 & 67.5 & 22.2 & 10.3 \\
\hline Business and management & 2.8 & 67.1 & 25.4 & 7.5 \\
\hline Medicine/health & 2.5 & 84.7 & 10.9 & 4.4 \\
\hline Law & $\ddagger$ & $\ddagger$ & $\ddagger$ & $\dot{t}+100$ \\
\hline Other & 2.8 & 69.8 & 19.9 & 10.3 \\
\hline
\end{tabular}

\# Rounds to zero.

$\$$ Reporting standards not met. (Too few cases for a reliable estimate.)

${ }^{1}$ Black includes African American, Pacific Islander includes Native Hawaiian, and Hispanic includes Latino. Included in the totals but not shown separately are data for American Indian/Alaska Native respondents and those who identified themselves with another race not shown. Race categories exclude Hispanic origin unless specified.

NOTE: Estimates include students from the 50 states, DC, and Puerto Rico. Detail may not sum to totals because of rounding. Standard error tables are available at http://nces.ed.gov/das/library/reports.asp.

SOURCE: U.S. Department of Education, National Center for Education Statistics, 1993/03 Baccalaureate and Beyond Longitudinal Study (B\&B:93/03). 
Table 18b. Among 1992-93 bachelor's degree recipients who had earned a master's degree by 2003, average number of years and percentage distribution of time from first graduate enrollment to completion of master's degree, by gender and marital and parental status 1 year before graduate enrollment

\begin{tabular}{lrrrr}
\hline & $\begin{array}{c}\text { Average } \\
\text { number of } \\
\text { Gears }\end{array}$ & \multicolumn{3}{c}{ Percentage distribution } \\
\cline { 3 - 5 } Gender and marital and parental status & or less & $\begin{array}{r}\text { More than 3 } \\
\text { to 5 years }\end{array}$ & $\begin{array}{r}\text { More than } \\
\text { 5 years }\end{array}$ \\
\hline Total & 2.7 & 69.9 & 21.7 & 8.5
\end{tabular}

Marital status year before graduate enrollment

Single

Married/cohabit as married

Divorced/separated/widowed

Number of dependent children year

before graduate enrollment

None

One or more

Male

\section{Total}

Marital status year before graduate enrollment

Single

Married/cohabit as married

Divorced/separated/widowed

Number of dependent children year

before graduate enrollment

None

One or more

\section{Female}

$$
\text { Total }
$$

Marital status year before graduate enrollment

Single

Married/cohabit as married

Divorced/separated/widowed

Number of dependent children year

before graduate enrollment

None

One or more
7.7
$¥$ Reporting standards not met. (Too few cases for a reliable estimate.)

NOTE: Estimates include students from the 50 states, DC, and Puerto Rico. Detail may not sum to totals because of rounding. Standard error tables are available at http://nces.ed.gov/das/library/reports.asp.

SOURCE: U.S. Department of Education, National Center for Education Statistics, 1993/03 Baccalaureate and Beyond Longitudinal Study (B\&B:93/03). 
Table 18c. Among 1992-93 bachelor's degree recipients who had earned a master's degree by 2003, average number of years and percentage distribution of time from first graduate enrollment to completion of master's degree, by graduate enrollment characteristics

\begin{tabular}{|c|c|c|c|c|}
\hline \multirow[b]{2}{*}{ Graduate enrollment characteristics } & \multirow{2}{*}{$\begin{array}{r}\text { Average } \\
\text { number of } \\
\text { years } \\
\end{array}$} & \multicolumn{3}{|c|}{ Percentage distribution } \\
\hline & & $\begin{array}{l}3 \text { years } \\
\text { or less }\end{array}$ & $\begin{array}{r}\text { More than } 3 \\
\text { to } 5 \text { years }\end{array}$ & $\begin{array}{r}\text { More than } \\
5 \text { years }\end{array}$ \\
\hline Total & 2.7 & 69.9 & 21.7 & 8.5 \\
\hline \multicolumn{5}{|l|}{$\begin{array}{l}\text { Time between bachelor's degree and } \\
\text { graduate enrollment }\end{array}$} \\
\hline 1 year or less & 2.9 & 66.0 & 24.1 & 10.0 \\
\hline More than 1 to 3 years & 2.9 & 65.2 & 22.2 & 12.6 \\
\hline More than 3 to 5 years & 2.7 & 68.1 & 24.7 & 7.2 \\
\hline More than 5 years & 2.1 & 87.3 & 12.7 & \# \\
\hline \multicolumn{5}{|l|}{ Continuity of graduate enrollment } \\
\hline Continuously enrolled & 2.3 & 82.1 & 15.5 & 2.4 \\
\hline Took off at least one semester or term & 3.1 & 58.5 & 27.4 & 14.1 \\
\hline \multicolumn{5}{|l|}{ Enrollment intensity } \\
\hline Exclusively full-time & 2.1 & 88.9 & 9.1 & 2.0 \\
\hline Exclusively part-time & 3.5 & 49.3 & 35.5 & 15.3 \\
\hline Mix of full-time and part-time & 2.7 & 81.9 & 9.8 & 8.3 \\
\hline
\end{tabular}

\section{First-Professional Degree}

First-professional degree programs are usually highly structured programs that take a set amount of time. First-professional degree recipients took about 4 years to finish that degree, and 87 percent finished within 5 years (table 19a). No gender differences were detected in their time to degree completion. Those who earned a first-professional degree were most likely to choose medical/health professions and law as their major fields of study (see table 13). A majority of health professions degree recipients ( 79 percent) took 3 to 5 years to finish a degree, the typical time for completing medical school. About 17 percent of health professions degree recipients finished a degree after more than 5 years. Most law degree recipients (79 percent) finished a degree within 3 years, the typical duration of law school, and 21 percent of them took more than 3 years to finish their law degree. 
Table 19a. Among 1992-93 bachelor's degree recipients who had earned a first-professional degree by 2003, average number of years and percentage distribution of time from first graduate enrollment to completion of first-professional degree, by selected student characteristics

\begin{tabular}{|c|c|c|c|c|c|}
\hline \multirow[b]{2}{*}{ Student characteristics } & \multirow{2}{*}{$\begin{array}{r}\text { Average } \\
\text { number of } \\
\text { years } \\
\end{array}$} & \multicolumn{4}{|c|}{ Percentage distribution } \\
\hline & & $\begin{array}{r}3 \text { years } \\
\text { or less } \\
\end{array}$ & $\begin{array}{r}\text { More than } 3 \\
\text { to } 5 \text { years }\end{array}$ & $\begin{array}{r}\text { More than } 5 \\
\text { to } 6 \text { years } \\
\end{array}$ & $\begin{array}{r}\text { More than } 6 \\
\text { to } 10 \text { years }\end{array}$ \\
\hline Total & 3.7 & 46.0 & 40.7 & 9.1 & 4.3 \\
\hline \multicolumn{6}{|l|}{ Gender } \\
\hline Male & 3.7 & 43.3 & 45.4 & 7.8 & 3.5 \\
\hline Female & 3.7 & 50.1 & 33.6 & 10.9 & 5.3 \\
\hline \multicolumn{6}{|l|}{ Race/ethnicity $^{1}$} \\
\hline White & 3.6 & 50.7 & 38.1 & 6.8 & 4.3 \\
\hline Black & $\ddagger$ & $\ddagger$ & $\ddagger$ & $\ddagger$ & $\ddagger$ \\
\hline Hispanic & $\ddagger$ & $\ddagger$ & $\ddagger$ & $\ddagger$ & $\ddagger$ \\
\hline Asian/Pacific Islander & 4.2 & 24.7 & 53.2 & 16.8 & 5.4 \\
\hline \multicolumn{6}{|c|}{ Age at bachelor's degree completion } \\
\hline 22 or younger & 3.8 & 43.8 & 41.7 & 10.1 & 4.4 \\
\hline $23-24$ & 3.8 & 38.9 & 51.4 & 6.4 & 3.4 \\
\hline $25-29$ & $\ddagger$ & $\ddagger$ & $\ddagger$ & $\ddagger$ & † \\
\hline 30 or older & $\ddagger$ & $\ddagger$ & $\ddagger$ & $\ddagger$ & 末 \\
\hline \multicolumn{6}{|c|}{ Highest education level by either parent } \\
\hline Less than high school & $\ddagger$ & $\ddagger$ & $\ddagger$ & $\ddagger$ & $\ddagger$ \\
\hline High school or equivalency & 3.3 & 60.6 & 31.5 & 3.4 & 4.5 \\
\hline Some postsecondary & 4.3 & 35.6 & 32.2 & 26.6 & 5.6 \\
\hline Bachelor's degree & 3.8 & 38.4 & 49.1 & 8.2 & 4.3 \\
\hline Advanced degree & 3.5 & 51.2 & 41.2 & 5.6 & 2.1 \\
\hline \multicolumn{6}{|l|}{ Major for first-professional degree } \\
\hline Arts and humanities & $\ddagger$ & $\ddagger$ & $\ddagger$ & $\ddagger$ & $\ddagger$ \\
\hline Social and behavioral sciences & $\ddagger$ & $\ddagger$ & $\ddagger$ & $\$$ & $\ddagger$ \\
\hline Life and physical sciences & $\ddagger$ & $\$$ & $\ddagger$ & $\ddagger$ & $\ddagger$ \\
\hline $\begin{array}{l}\text { Engineering, mathematics, } \\
\text { computer science }\end{array}$ & $\ddagger$ & \pm & $t$ & $t$ & $\neq$ \\
\hline Education & $\ddagger$ & $\ddagger$ & $\ddagger$ & $\ddagger$ & $\ddagger$ \\
\hline Business and management & $\ddagger$ & $\ddagger$ & $\ddagger$ & $\ddagger$ & $\ddagger$ \\
\hline Medicine/health & 4.3 & 4.2 & 79.3 & 10.4 & 6.2 \\
\hline Law & 3.1 & 78.5 & 13.6 & 5.7 & 2.3 \\
\hline Other & $\ddagger$ & $\ddagger$ & $\ddagger$ & $\ddagger$ & $\ddagger$ \\
\hline
\end{tabular}

$\$$ Reporting standards not met. (Too few cases for a reliable estimate.)

${ }^{1}$ Black includes African American, Pacific Islander includes Native Hawaiian, and Hispanic includes Latino. Included in the totals but not shown separately are data for American Indian/Alaska Native respondents and those who identified themselves with another race not shown. Race categories exclude Hispanic origin unless specified.

NOTE: Estimates include students from the 50 states, DC, and Puerto Rico. Detail may not sum to totals because of rounding. Standard error tables are available at http://nces.ed.gov/das/library/reports.asp.

SOURCE: U.S. Department of Education, National Center for Education Statistics, 1993/03 Baccalaureate and Beyond Longitudinal Study (B\&B:93/03). 
Overall, single and married students did not differ in terms of the number of years it took them to finish a first-professional degree (table 19b). However, married students appeared to be more likely than their single counterparts to finish a first-professional degree within 3 years (65 vs. 43 percent), whereas single students were more likely to finish in 3 to 5 years (44 vs. 19 percent). Because few first-professional degree recipients had dependent children before graduate enrollment, statistical comparisons were not possible.

First-professional degree recipients who interrupted their enrollment took more time to complete a first-professional degree than those who did not take a break (4 vs. 3 years) (table 19c). No difference in time to degree was found between those who had enrolled in a graduate degree program immediately after completing a bachelor's degree and those who had delayed their enrollment for 1 to 3 years. Because few first-professional degree recipients attended part time, comparison between full- and part-time students was not possible.

\section{Doctoral Degree}

Doctoral degree recipients took about 6 years to complete that degree (table 20a). About two-thirds (65 percent) took more than 5 years to finish, 29 percent took 3 to 5 years to finish, and the remaining 6 percent finished within 3 years. National data from the Survey of Earned Doctorates reported the median number of years it takes students to complete a doctoral degree is 8 years (Hoffer et al. 2005). Because so few students had earned a doctoral degree by 2003 (only 5 percent of all graduate students; see table 12), comparisons between many subgroups of doctoral degree recipients were not possible due to small sample sizes and large standard errors (tables 20a, 20b, and 20c), with the exception that doctoral degree students who were enrolled continuously took less time to earn a degree than those who were not continuously enrolled (5 vs. 6 years) (table 20c). Although women appeared to be more likely than men to complete a doctoral degree within 3 years (11 vs. 3 percent), and men appeared to be more likely than women to finish in more than 6 years ( 29 vs. 22 percent), none of these differences were statistically measurable. 
Table 19b. Among 1992-93 bachelor's degree recipients who had earned a first-professional degree by 2003, average number of years and percentage distribution of time from first graduate enrollment to completion of first-professional degree, by gender and marital and parental status 1 year before graduate enrollment

Gender and marital and
parental status

Average number of years

\begin{tabular}{cccr}
\multicolumn{4}{c}{ Percentage distribution } \\
\hline $\begin{array}{c}\text { 3 years } \\
\text { or less }\end{array}$ & $\begin{array}{c}\text { More than 3 } \\
\text { to 5 years }\end{array}$ & $\begin{array}{c}\text { More than 5 } \\
\text { to 6 years }\end{array}$ & $\begin{array}{r}\text { More than 6 } \\
\text { to 10 years }\end{array}$ \\
\hline
\end{tabular}

Total

3.7

46.0

40.7

9.1

Marital status year before graduate enrollment

Single

Married/cohabit as married

Divorced/separated/widowed

Number of dependent children year

before graduate enrollment

None

One or more

3.8

$\ddagger$

Male

Total

3.7

3.4

$\ddagger$

43.4

64.9

$\ddagger$

†

43.4

$\ddagger$

43.3

45.4

7.8

3.5

Marital status year before graduate enrollment

Single

Married/cohabit as married

Divorced/separated/widowed

$\begin{array}{rr}3.8 & 39.0 \\ \ddagger & \\ \ddagger & \end{array}$

39.0
$\ddagger$
$\ddagger$

49.4

$\ddagger$

43.7
19.0

8.4

4.6

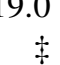

42.5

$\ddagger$

9.6

$\ddagger$

4.5

Number of dependent children year before graduate enrollment

3.8

None

One or more

50.1

33.6

10.9

Marital status year before graduate enrollment

\section{Single}

Married/cohabit as married

Divorced/separated/widowed

Number of dependent children year

before graduate enrollment

None

One or more

$$
40.7
$$

$\ddagger$

47.4

$\ddagger$

8.3

$\ddagger$

3.7

$\ddagger$

$\$$ Reporting standards not met. (Too few cases for a reliable estimate.)

NOTE: Estimates include students from the 50 states, DC, and Puerto Rico. Detail may not sum to totals because of rounding.

Standard error tables are available at http://nces.ed.gov/das/library/reports.asp.

SOURCE: U.S. Department of Education, National Center for Education Statistics, 1993/03 Baccalaureate and Beyond

Longitudinal Study (B\&B:93/03). 
Table 19c. Among 1992-93 bachelor's degree recipients who had earned a first-professional degree by 2003, average number of years and percentage distribution of time from first graduate enrollment to completion of first-professional degree, by graduate enrollment characteristics

\begin{tabular}{lrrrrr}
\hline \multirow{2}{*}{$\begin{array}{l}\text { Graduate enrollment } \\
\text { characteristics }\end{array}$} & $\begin{array}{c}\text { Average } \\
\text { number of } \\
\text { years }\end{array}$ & $\begin{array}{c}\text { 3 years } \\
\text { or less }\end{array}$ & $\begin{array}{c}\text { More than 3 } \\
\text { to 5 years }\end{array}$ & $\begin{array}{c}\text { More than 5 } \\
\text { to 6 years }\end{array}$ & $\begin{array}{r}\text { More than 6 } \\
\text { to 10 years }\end{array}$ \\
\hline \multirow{2}{*}{ Total } & 3.7 & 46.0 & 40.7 & 9.1 & 4.3
\end{tabular}

Time between bachelor's degree and graduate enrollment

\begin{tabular}{|c|c|c|c|c|c|}
\hline 1 year or less & 3.9 & 40.7 & 45.9 & 7.7 & 5.8 \\
\hline More than 1 to 3 years & 3.5 & 51.5 & 37.6 & 8.4 & 2.6 \\
\hline More than 3 to 5 years & $\ddagger$ & $\ddagger$ & $\ddagger$ & $\ddagger$ & $\ddagger$ \\
\hline More than 5 years & $\ddagger$ & $\ddagger$ & $\ddagger$ & $\ddagger$ & $\ddagger$ \\
\hline \multicolumn{6}{|l|}{ Continuity of graduate enrollment } \\
\hline Continuously enrolled & 3.4 & 52.9 & 40.7 & 5.3 & 1.2 \\
\hline $\begin{array}{l}\text { Took off at least one semester } \\
\text { or term }\end{array}$ & 4.4 & 29.0 & 40.9 & 18.4 & 11.7 \\
\hline \multicolumn{6}{|l|}{ Enrollment intensity } \\
\hline Exclusively full-time & 3.6 & 47.2 & 41.5 & 8.5 & 2.7 \\
\hline Exclusively part-time & $\ddagger$ & $\ddagger$ & $\ddagger$ & $\ddagger$ & $\ddagger$ \\
\hline Mix of full-time and part-time & $\ddagger$ & $\ddagger$ & $\ddagger$ & $\ddagger$ & $\ddagger$ \\
\hline
\end{tabular}

$\ddagger$ Reporting standards not met. (Too few cases for a reliable estimate.)

NOTE: Estimates include students from the 50 states, DC, and Puerto Rico. Detail may not sum to totals because of rounding. Standard error tables are available at http://nces.ed.gov/das/library/reports.asp.

SOURCE: U.S. Department of Education, National Center for Education Statistics, 1993/03 Baccalaureate and Beyond Longitudinal Study (B\&B:93/03). 
Table 20a. Among 1992-93 bachelor's degree recipients who had earned a doctoral degree by 2003, average number of years and percentage distribution of time from first graduate enrollment to completion of doctoral degree, by selected student characteristics

\begin{tabular}{|c|c|c|c|c|c|}
\hline \multirow[b]{2}{*}{ Student characteristics } & \multirow{2}{*}{$\begin{array}{r}\text { Average } \\
\text { number of } \\
\text { years } \\
\end{array}$} & \multicolumn{4}{|c|}{ Percentage distribution } \\
\hline & & $\begin{array}{l}3 \text { years } \\
\text { or less }\end{array}$ & $\begin{array}{r}\text { More than } 3 \\
\text { to } 5 \text { years }\end{array}$ & $\begin{array}{r}\text { More than } 5 \\
\text { to } 6 \text { years }\end{array}$ & $\begin{array}{l}\text { More than } 6 \\
\text { to } 10 \text { years }\end{array}$ \\
\hline Total & 5.8 & 5.9 & 28.9 & 38.6 & 26.6 \\
\hline \multicolumn{6}{|l|}{ Gender } \\
\hline Male & 6.0 & 2.9 & 28.3 & 39.3 & 29.5 \\
\hline Female & 5.6 & 11.0 & 29.9 & 37.3 & 21.8 \\
\hline \multicolumn{6}{|l|}{ Race/ethnicity $^{1}$} \\
\hline White & 5.8 & 6.5 & 29.1 & 36.9 & 27.5 \\
\hline Black & $\ddagger$ & $\ddagger$ & $\ddagger$ & $\ddagger$ & 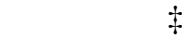 \\
\hline Hispanic & $\ddagger$ & $\ddagger$ & $\ddagger$ & $\ddagger$ & 末 \\
\hline Asian/Pacific Islander & $\ddagger$ & $\ddagger$ & $\ddagger$ & $\ddagger$ & $\ddagger$ \\
\hline \multicolumn{6}{|c|}{ Age at bachelor's degree completion } \\
\hline 22 or younger & 5.7 & 6.2 & 32.2 & 34.5 & 27.2 \\
\hline $23-24$ & $\ddagger$ & $\ddagger$ & $\ddagger$ & $\ddagger$ & $\ddagger$ \\
\hline $25-29$ & $\ddagger$ & $\ddagger$ & $\ddagger$ & $\ddagger$ & $\ddagger$ \\
\hline 30 or older & $\ddagger$ & $\ddagger$ & $\ddagger$ & $\ddagger$ & $\ddagger$ \\
\hline \multicolumn{6}{|c|}{ Highest education level by either parent } \\
\hline Less than high school & $\ddagger$ & $\ddagger$ & $\ddagger$ & $\ddagger$ & $\ddagger$ \\
\hline High school or equivalency & $\ddagger$ & $\ddagger$ & $\ddagger$ & $\ddagger$ & $\ddagger$ \\
\hline Some postsecondary & $\ddagger$ & $\ddagger$ & $\ddagger$ & $\ddagger$ & \$ \\
\hline Bachelor's degree & 5.6 & 7.9 & 28.2 & 52.1 & 11.9 \\
\hline Advanced degree & 5.9 & 3.4 & 28.3 & 45.4 & 23.0 \\
\hline \multicolumn{6}{|l|}{ Major for doctoral degree } \\
\hline Arts and humanities & $\ddagger$ & $\ddagger$ & $\ddagger$ & $\ddagger$ & $\ddagger$ \\
\hline Social and behavioral sciences & $\ddagger$ & $\ddagger$ & $\ddagger$ & $\ddagger$ & $\ddagger$ \\
\hline Life and physical sciences & 6.0 & 1.5 & 24.3 & 52.7 & 21.6 \\
\hline Engineering, mathematics, & & & & & \\
\hline computer science & $\ddagger$ & $\ddagger$ & $\ddagger$ & $\ddagger$ & 末 \\
\hline Education & $\ddagger$ & $\ddagger$ & $\ddagger$ & $\ddagger$ & 末 \\
\hline Business and management & $\ddagger$ & $\ddagger$ & $\ddagger$ & $\ddagger$ & † \\
\hline Medicine/health & $\ddagger$ & $\ddagger$ & $\ddagger$ & $\ddagger$ & † \\
\hline Law & $\ddagger$ & $\ddagger$ & $\ddagger$ & $\ddagger$ & † \\
\hline Other & 5.5 & 6.8 & 43.3 & 18.0 & 31.9 \\
\hline
\end{tabular}

$\$$ Reporting standards not met. (Too few cases for a reliable estimate.)

${ }^{1}$ Black includes African American, Pacific Islander includes Native Hawaiian, and Hispanic includes Latino. Included in the totals but not shown separately are data for American Indian/Alaska Native respondents and those who identified themselves with another race not shown. Race categories exclude Hispanic origin unless specified.

NOTE: Estimates include students from the 50 states, DC, and Puerto Rico. Detail may not sum to totals because of rounding. Standard error tables are available at http://nces.ed.gov/das/library/reports.asp.

SOURCE: U.S. Department of Education, National Center for Education Statistics, 1993/03 Baccalaureate and Beyond Longitudinal Study (B\&B:93/03). 
Table 20b. Among 1992-93 bachelor's degree recipients who had earned a doctoral degree by 2003, average number of years and percentage distribution of time from first graduate enrollment to completion of doctoral degree, by gender and marital and parental status 1 year before graduate enrollment

Gender and marital and
parental status

Average number of years
Percentage distribution

\begin{tabular}{cccc}
\hline $\begin{array}{c}3 \text { years } \\
\text { or less }\end{array}$ & $\begin{array}{c}\text { More than } 3 \\
\text { to } 5 \text { years }\end{array}$ & $\begin{array}{c}\text { More than } 5 \\
\text { to } 6 \text { years }\end{array}$ & $\begin{array}{r}\text { More than } 6 \\
\text { to } 10 \text { years }\end{array}$ \\
\hline
\end{tabular}

Total

5.8

5.9

28.9

38.6

26.6

Marital status year before graduate enrollment

$$
\text { Single }
$$

Married/cohabit as married

Divorced/separated/widowed

$\begin{array}{rr}5.9 & 5.0 \\ \ddagger & \ddagger \\ \ddagger & \ddagger\end{array}$

29.3

$\ddagger$

38.2

$\ddagger$

Number of dependent children year

before graduate enrollment

None

One or more

$\begin{array}{rr}5.9 & 5.7 \\ \ddagger & \ddagger\end{array}$

2.9

28.3

39.3

29.5

Total

6.0

5.9

enrollment

Single

Married/cohabit as married

Divorced/separated/widowed

Number of dependent children year

before graduate enrollment

None

One or more

6.0

$\ddagger$

3.1

$\ddagger$

3.6

$\ddagger$

29.3

$\ddagger$

38.7

$\ddagger$

$\ddagger$

$+$

27.9

$\ddagger$

Female

Total

5.6

11.0

29.9

37.3

21.8

Marital status year before graduate enrollment

\section{Single}

Married/cohabit as married

Divorced/separated/widowed

Number of dependent children year

before graduate enrollment

None

5.7

5.8
$\ddagger$
$\ddagger$

29.3

$\ddagger$
37.2

26.2

$\ddagger$

$\ddagger$

$\ddagger$

One or more

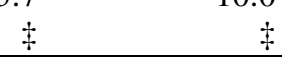

$¥$ Reporting standards not met. (Too few cases for a reliable estimate.)

NOTE: Estimates include students from the 50 states, DC, and Puerto Rico. Detail may not sum to totals because of rounding.

Standard error tables are available at http://nces.ed.gov/das/library/reports.asp.

SOURCE: U.S. Department of Education, National Center for Education Statistics, 1993/03 Baccalaureate and Beyond

Longitudinal Study (B\&B:93/03). 
Table 20c. Among 1992-93 bachelor's degree recipients who had earned a doctoral degree by 2003, average number of years and percentage distribution of time from first graduate enrollment to completion of doctoral degree, by graduate enrollment characteristics

\begin{tabular}{|c|c|c|c|c|c|}
\hline \multirow[b]{2}{*}{$\begin{array}{l}\text { Graduate enrollment } \\
\text { characteristics }\end{array}$} & \multirow{2}{*}{$\begin{array}{r}\text { Average } \\
\text { number of } \\
\text { years } \\
\end{array}$} & \multicolumn{4}{|c|}{ Percentage distribution } \\
\hline & & $\begin{array}{l}3 \text { years } \\
\text { or less }\end{array}$ & $\begin{array}{r}\text { More than } 3 \\
\text { to } 5 \text { years }\end{array}$ & $\begin{array}{r}\text { More than } 5 \\
\text { to } 6 \text { years }\end{array}$ & $\begin{array}{r}\text { More than } 6 \\
\text { to } 10 \text { years }\end{array}$ \\
\hline Total & 5.8 & 5.9 & 28.9 & 38.6 & 26.6 \\
\hline \multicolumn{6}{|l|}{$\begin{array}{l}\text { Time between bachelor's degree } \\
\text { and graduate enrollment }\end{array}$} \\
\hline 1 year or less & 6.1 & 4.1 & 25.6 & 37.2 & 33.1 \\
\hline More than 1 to 3 years & 5.5 & 7.1 & 32.5 & 45.8 & 14.6 \\
\hline More than 3 to 5 years & $\ddagger$ & $\ddagger$ & $\ddagger$ & $\ddagger$ & $\ddagger$ \\
\hline More than 5 years & $\ddagger$ & $\ddagger$ & $\$$ & $\ddagger$ & $\ddagger$ \\
\hline \multicolumn{6}{|l|}{ Continuity of graduate enrollment } \\
\hline Continuously enrolled & 5.4 & 7.1 & 40.1 & 37.6 & 15.2 \\
\hline $\begin{array}{l}\text { Took off at least one semester } \\
\text { or term }\end{array}$ & 6.4 & 4.6 & 16.2 & 39.6 & 39.6 \\
\hline \multicolumn{6}{|l|}{ Enrollment intensity } \\
\hline Exclusively full-time & 5.8 & 6.5 & 28.8 & 40.5 & 24.3 \\
\hline Exclusively part-time & $\ddagger$ & $\ddagger$ & $\ddagger$ & $\ddagger$ & $\ddagger$ \\
\hline Mix of full-time and part-time & $\ddagger$ & $\ddagger$ & $\ddagger$ & $\ddagger$ & $\ddagger$ \\
\hline
\end{tabular}

\$ Reporting standards not met. (Too few cases for a reliable estimate.)

NOTE: Estimates include students from the 50 states, DC, and Puerto Rico. Detail may not sum to totals because of rounding. Standard error tables are available at http://nces.ed.gov/das/library/reports.asp.

SOURCE: U.S. Department of Education, National Center for Education Statistics, 1993/03 Baccalaureate and Beyond Longitudinal Study (B\&B:93/03). 


\section{Factors Related to Graduate Enrollment, Persistence, and Attainment}

The tabular analyses described in this report show that many factors are related to graduate enrollment, persistence, and attainment. However, these relationships are bivariate and may reflect more complex relationships among multiple factors. For example, while the findings presented in table 12 indicate that younger students were more likely than older students to have earned a graduate degree by 2003 , this may be due partially to the fact that younger students were more likely to enroll full time and were less likely to take time off (table 11), two factors significantly related to graduate degree completion (table 15). Because a bivariate relationship may conceal more complex relationships among several variables, the next step in this analysis is to examine the unique relationship between two variables while taking other variables into account. This approach is sometimes referred to as "commonality analysis," in which a multiple linear regression is used to look at the relationship between an independent variable and an outcome variable while adjusting for the common variation among a group of independent variables. ${ }^{12}$

For the purpose of this study, commonality analysis was performed on three outcome variables. The first analysis focuses on factors related to students' likelihood of enrolling in a graduate degree program after receiving a bachelor's degree. The independent variables examined in this analysis include demographic characteristics (gender, race/ethnicity, age, parents' education, marital status, and dependent status); academic characteristics (bachelor's degree major, bachelor's degree GPA); and educational expectations at the time of bachelor's degree completion. The second analysis examines factors related to the likelihood that graduate students had completed a graduate degree by 2003 . The independent variables examined in the second and third analysis include student characteristics (age, gender, race/ethnicity, marital and parental status before graduate enrollment, and parents' education); academic characteristics (educational expectations, undergraduate major and GPA, and type of bachelor's degree-granting institution); and graduate enrollment characteristics (entry time, enrollment continuity and intensity, type of program, graduate degree major, and whether the student ever received grants, employer assistance, or a tuition waiver). The last analysis broadens the definition of degree

\footnotetext{
12 See Technical Notes and Methodology in appendix B for more information about multivariate commonality analysis.
} 
completion to include students who had completed a graduate degree or were still enrolled in a graduate degree program as of 2003 (often referred to as "persistence to a degree").

\section{Graduate Enrollment}

The results of the analysis examining students' likelihood of enrolling in a graduate degree program are shown in table 21. All 1992-93 bachelor's degree recipients are included in the table. The first column shows the percentage of students who had enrolled in a graduate degree program by 2003 before controlling for all independent variables included in the model. The second column presents the least squares coefficients (expressed as percentages) from the commonality analysis. These coefficients represent the difference (either higher or lower) in percentage points that might be expected between the analysis group (e.g., male students) and the comparison group (e.g., female students) after controlling for the interrelationship of all other independent variables included in the analysis. Comparison groups are shown in italics. Significant least squares coefficients (indicated by asterisks) mean that the observed differences in the likelihood of attaining a graduate degree between the comparison groups and the analysis groups remain even after taking into account the covariation of all other independent variables.

The relationship between two demographic variables (race/ethnicity and number of dependents) and graduate enrollment diminished after controlling for all other independent variables. After controlling for other factors, many demographic and academic characteristics (students' age, undergraduate major and GPA, marital status, educational expectations, and parents' education) maintained a significant relationship with enrollment in graduate school. For example, enrollment rates among students age 22 or younger were higher than among students ages 23-29. The relationship between graduate enrollment and parents' highest education level only partially remained. Students whose parents held a graduate degree were more likely to enroll in a graduate program than students whose parents had a high school degree or equivalent.

Academic characteristics from students' undergraduate experience retained a significant relationship with enrollment in a graduate or first-professional degree program. Regardless of all other characteristics, students who had majored in biological sciences as undergraduates were more likely to enroll in graduate school than students who had majored in business and management, engineering, public affairs/social services, mathematics and other sciences, social science, and other fields. Students' undergraduate academic achievement retained a strong positive relationship with graduate enrollment, with students who had GPAs of 3.5 or above being more likely to enroll than those with lower GPAs. 
Table 21. Among 1992-93 bachelor's degree recipients, percentage who had enrolled in a graduate or firstprofessional degree program by 2003 and least squares coefficients and standard errors, by selected student characteristics

\begin{tabular}{|c|c|c|c|}
\hline \multirow[b]{2}{*}{ Student characteristics } & \multicolumn{3}{|c|}{ Any graduate enrollment } \\
\hline & $\begin{array}{r}\text { Unadjusted } \\
\text { percentages }{ }^{1}\end{array}$ & $\begin{array}{r}\text { Least squares } \\
\text { coefficient }^{2} \\
\end{array}$ & $\begin{array}{r}\begin{array}{r}\text { Standard } \\
\text { error }\end{array} \\
\end{array}$ \\
\hline Total & 40.0 & 33.8 & 5.37 \\
\hline \multicolumn{4}{|l|}{ Gender } \\
\hline Female & 38.6 & -1.5 & 2.22 \\
\hline Male & 41.1 & $\dagger$ & $\dagger$ \\
\hline \multicolumn{4}{|l|}{ Race/ethnicity ${ }^{4}$} \\
\hline Black & $45.4 *$ & 7.0 & 4.45 \\
\hline Hispanic & 43.7 & 5.7 & 4.82 \\
\hline Asian/Pacific Islander & 41.5 & -0.8 & 4.82 \\
\hline White & 39.2 & $\dagger$ & $\dagger$ \\
\hline \multicolumn{4}{|l|}{ Age at bachelor's degree completion } \\
\hline $23-24$ & $32.1 *$ & $-8.7 *$ & 2.59 \\
\hline $25-29$ & $27.2 *$ & $-12.1 *$ & 3.52 \\
\hline 30 or older & $36.2 *$ & -6.5 & 3.52 \\
\hline 22 or younger & 48.3 & $\dagger$ & $\dagger$ \\
\hline \multicolumn{4}{|c|}{ Highest education level by either parent } \\
\hline Less than high school & $33.7 *$ & -8.2 & 5.56 \\
\hline High school or equivalency & $33.7 *$ & $-6.9 *$ & 2.96 \\
\hline Some postsecondary & $39.1 *$ & -4.2 & 3.15 \\
\hline Bachelor's degree & $39.7 *$ & -3.4 & 2.96 \\
\hline Advanced degree & 48.5 & $\dagger$ & $\dagger$ \\
\hline \multicolumn{4}{|l|}{ Baccalaureate degree major } \\
\hline Business and management & $25.3 *$ & $-24.6 *$ & 5.37 \\
\hline Education & $50.1 *$ & -6.5 & 7.22 \\
\hline Engineering & $39.2 *$ & $-17.8 *$ & 5.56 \\
\hline Health professions & $36.3 *$ & -5.1 & 5.74 \\
\hline Public affairs/social services & $36.0 *$ & $-12.5 *$ & 6.30 \\
\hline Mathematics and other sciences & $48.6 *$ & $-15.8 *$ & 6.30 \\
\hline Social science & $47.9 *$ & $-16.5 *$ & 7.41 \\
\hline History & $51.9 *$ & -8.5 & 6.48 \\
\hline Humanities & $40.7 *$ & -10.1 & 5.93 \\
\hline Psychology & $55.0 *$ & -7.6 & 9.08 \\
\hline Other & $34.3 *$ & $-16.8 *$ & 5.93 \\
\hline Biological sciences & 66.9 & $\dagger$ & + \\
\hline \multicolumn{4}{|l|}{ Bachelor's degree GPA } \\
\hline Under 2.5 & $23.5 *$ & $-23.0 *$ & 3.52 \\
\hline $2.5-2.99$ & $35.6 *$ & $-14.4 *$ & 2.96 \\
\hline $3.0-3.49$ & $43.4 *$ & $-9.2 *$ & 2.78 \\
\hline 3.5 or above & 52.2 & $\dagger$ & $\dagger$ \\
\hline
\end{tabular}

See notes at end of table. 
Table 21. Among 1992-93 bachelor's degree recipients, percentage who had enrolled in a graduate or firstprofessional degree program by 2003 and least squares coefficients and standard errors, by selected student characteristics-Continued

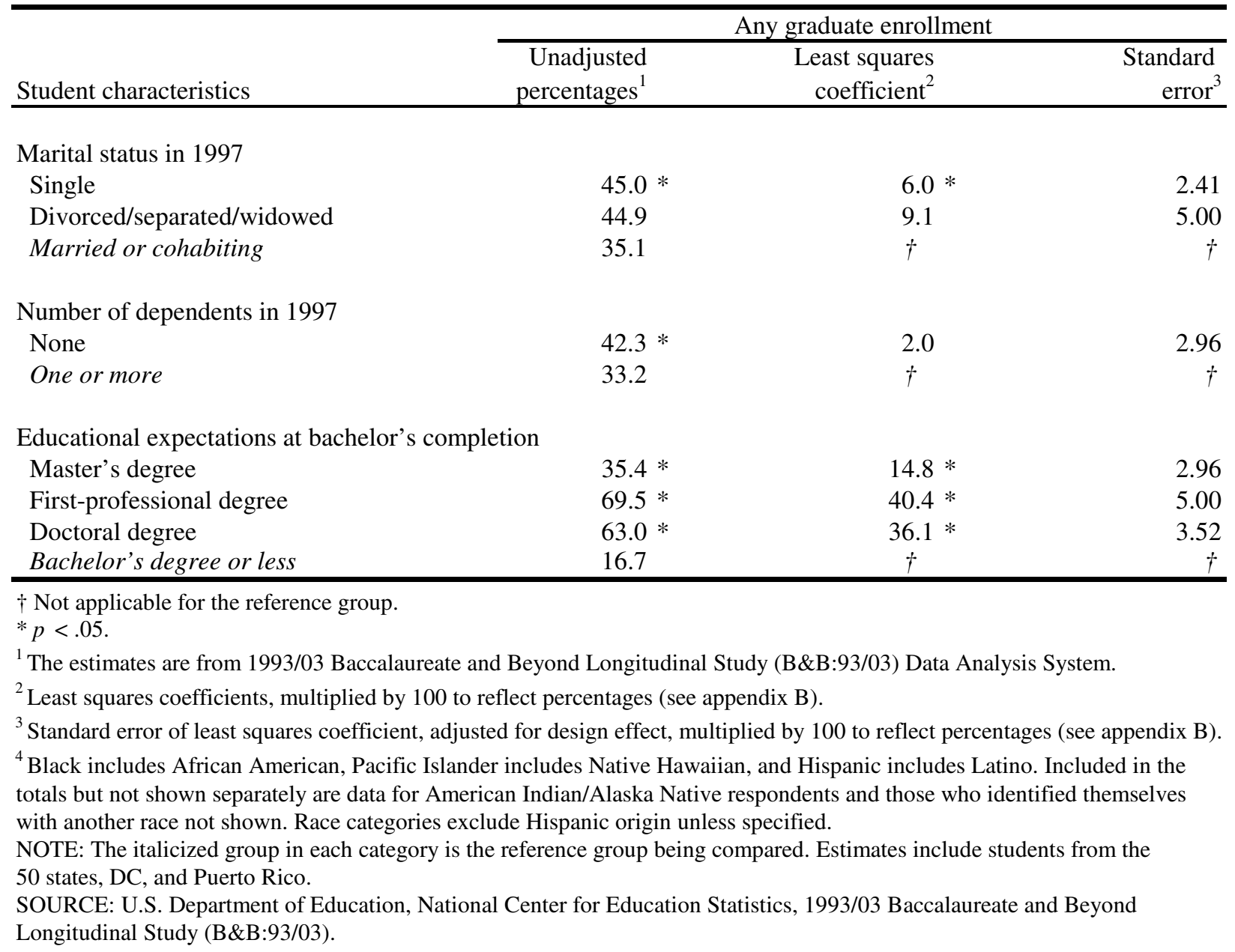

\section{Completion of Graduate Degrees}

The results of the analysis examining students' likelihood of earning a graduate degree are presented in table 22. Only bachelor's degree recipients enrolled in a graduate degree program were included. The first column provides the observed percentages - that is, the proportion of students who had earned a graduate degree by 2003 before controlling for all independent variables included in the analysis. The second column presents the least squares coefficients (expressed as percentages) from the commonality analysis.

The relationship between many demographic variables (e.g., students' race/ethnicity, marital and parental status, educational expectations, and parents' education) and graduate degree 
Table 22. Among 1992-93 bachelor's degree recipients who had enrolled in a graduate degree program by 2003 , percentage who had attained a graduate degree by 2003 and percentage who had attained a graduate degree or were still enrolled in a graduate program by 2003 and least squares coefficients and standard errors, by selected student characteristics

\begin{tabular}{|c|c|c|c|c|c|c|}
\hline \multirow[b]{2}{*}{ Student characteristics } & \multicolumn{3}{|c|}{ Attained a graduate degree } & \multicolumn{3}{|c|}{$\begin{array}{l}\text { Attained a graduate degree or were } \\
\text { still enrolled in a graduate program }\end{array}$} \\
\hline & $\begin{array}{r}\text { Unadjusted } \\
\text { percentages }{ }^{1}\end{array}$ & $\begin{array}{r}\text { Least squares } \\
\text { coefficient }^{2} \\
\end{array}$ & $\begin{array}{r}\text { Standard } \\
\text { error }^{3} \\
\end{array}$ & $\begin{array}{r}\text { Unadjusted } \\
\text { percentages }^{1}\end{array}$ & $\begin{array}{r}\text { Least squares } \\
\text { coefficient }^{2} \\
\end{array}$ & $\begin{array}{r}\text { Standard } \\
\text { error }^{3} \\
\end{array}$ \\
\hline Total & 61.9 & 19.2 & 12.84 & 76.5 & 49.8 & 13.05 \\
\hline \multicolumn{7}{|l|}{ Gender } \\
\hline Female & 63.6 & -3.1 & 3.50 & 75.0 & -3.5 & 3.60 \\
\hline Male & 60.5 & $\dagger$ & $t$ & 78.5 & $t$ & $\dagger$ \\
\hline \multicolumn{7}{|l|}{ Race/ethnicity $^{4}$} \\
\hline Black & 57.9 & -4.5 & 6.61 & 79.0 & 2.7 & 6.75 \\
\hline Hispanic & 59.1 & -3.3 & 7.39 & 75.2 & -1.1 & 7.42 \\
\hline Asian/Pacific Islander & 61.5 & -0.9 & 7.78 & 77.9 & 1.6 & 7.87 \\
\hline American Indian/Alaska Native & 66.1 & 3.7 & 27.62 & 81.5 & 5.2 & 28.12 \\
\hline White & 62.4 & $\dagger$ & $\dagger$ & 76.3 & $t$ & $\dagger$ \\
\hline \multicolumn{7}{|l|}{ Age at bachelor's degree completion } \\
\hline $23-24$ & $55.2^{*}$ & $-9.4^{*}$ & 4.28 & 72.7 & -6.0 & 4.50 \\
\hline $25-29$ & 57.9 & -6.7 & 6.61 & 73.9 & -4.8 & 6.75 \\
\hline 30 or older & 62.4 & -2.2 & 7.00 & 74.9 & -3.8 & 7.20 \\
\hline 22 or younger & 64.6 & $\dagger$ & $\dagger$ & 78.7 & $t$ & $\dagger$ \\
\hline \multicolumn{7}{|c|}{ Highest education level by either parent } \\
\hline Less than high school & 58.0 & -6.5 & 9.53 & 74.6 & -3.6 & 9.67 \\
\hline High school or equivalency & 59.6 & -4.9 & 4.86 & 73.7 & -4.5 & 4.95 \\
\hline Some postsecondary & 61.6 & -2.9 & 4.86 & 76.3 & -1.9 & 4.95 \\
\hline Bachelor's degree & 61.3 & -3.2 & 4.47 & 77.5 & -0.7 & 4.50 \\
\hline Advanced degree & 64.5 & $\dagger$ & $\dagger$ & 78.2 & $\dagger$ & $\dagger$ \\
\hline \multicolumn{7}{|c|}{$\begin{array}{l}\text { Educational expectations at bachelor's } \\
\text { degree in } 1993\end{array}$} \\
\hline Master's degree & 62.8 & 5.2 & 7.20 & 78.3 & 0.8 & 7.20 \\
\hline First-professional degree & 63.6 & 6.0 & 8.75 & 75.6 & -1.9 & 9.00 \\
\hline Doctoral degree & 60.6 & 3.0 & 7.39 & 74.0 & -3.5 & 7.65 \\
\hline Bachelor's degree or less & 57.6 & $\dagger$ & $\dagger$ & 77.5 & $\dagger$ & $\dagger$ \\
\hline \multicolumn{7}{|l|}{$\begin{array}{l}\text { Marital status year before graduate } \\
\text { enrollment }\end{array}$} \\
\hline Single & 62.7 & 2.7 & 4.47 & 76.7 & 0.9 & 4.50 \\
\hline Divorced/separated/widowed & 61.5 & 1.5 & 8.75 & 80.3 & 4.5 & 9.00 \\
\hline Married/cohabit as married & 60.0 & $\dagger$ & $\dagger$ & 75.8 & $\dagger$ & $\dagger$ \\
\hline \multicolumn{7}{|l|}{$\begin{array}{l}\text { Number of dependent children year } \\
\text { before graduate enrollment }\end{array}$} \\
\hline One or more & 58.9 & -3.4 & 6.42 & 77.8 & 1.5 & 6.52 \\
\hline None & 62.3 & $t$ & $\dagger$ & 76.3 & $\dagger$ & $\dagger$ \\
\hline \multicolumn{7}{|l|}{$\begin{array}{l}\text { Time between bachelor's degree } \\
\text { and graduate enrollment }\end{array}$} \\
\hline More than 1 to 3 years & 64.6 & -4.2 & 4.28 & 73.7 & 0.2 & 4.27 \\
\hline More than 3 to 5 years & 64.1 & -4.7 & 5.45 & 75.7 & 2.2 & 5.62 \\
\hline More than 5 years & $43.6^{*}$ & $-25.2 *$ & 5.83 & $87.1^{k}$ & $13.6^{*}$ & 5.85 \\
\hline 1 year or less & 68.8 & $t$ & + & 73.5 & $t$ & $\dagger$ \\
\hline
\end{tabular}


Table 22. Among 1992-93 bachelor's degree recipients who had enrolled in a graduate degree program by 2003 , percentage who had attained a graduate degree by 2003 and percentage who had attained a graduate degree or were still enrolled in a graduate program by 2003 and least squares coefficients and standard errors, by selected student characteristics-Continued

\begin{tabular}{|c|c|c|c|c|c|c|}
\hline \multirow[b]{2}{*}{ Student characteristics } & \multicolumn{3}{|c|}{ Attained a graduate degree } & \multicolumn{3}{|c|}{$\begin{array}{l}\text { Attained a graduate degree or were } \\
\text { still enrolled in a graduate program }\end{array}$} \\
\hline & $\begin{array}{r}\text { Unadjusted } \\
\text { percentages }^{1}\end{array}$ & $\begin{array}{r}\text { Least squares } \\
\text { coefficient }^{2} \\
\end{array}$ & $\begin{array}{r}\text { Standard } \\
\text { error }^{3} \\
\end{array}$ & $\begin{array}{r}\text { Unadjusted } \\
\text { percentages } \\
\end{array}$ & $\begin{array}{r}\text { Least squares } \\
\text { coefficient }^{2} \\
\end{array}$ & $\begin{array}{r}\text { Standard } \\
\text { error }^{3} \\
\end{array}$ \\
\hline \multicolumn{7}{|l|}{ Highest graduate enrollment } \\
\hline Master & $65.8 *$ & $21.1 *$ & 6.61 & 76.3 & -0.4 & 6.75 \\
\hline First-professional & 53.4 & 8.7 & 8.95 & 77.6 & 0.9 & 9.00 \\
\hline Doctoral & 44.7 & $\dagger$ & $\dagger$ & 76.7 & $\dagger$ & $\dagger$ \\
\hline \multicolumn{7}{|l|}{ Multiple graduate enrollment } \\
\hline Multiple enrollment & $68.7 *$ & $9.1 *$ & 4.47 & $90.8 *$ & $19.1 *$ & 4.50 \\
\hline Single enrollment & 59.6 & $\dagger$ & + & 71.7 & $\dagger$ & $\dagger$ \\
\hline \multicolumn{7}{|l|}{ Continuity of graduate enrollment } \\
\hline Continuously enrolled & $67.9 *$ & $11.5 *$ & 3.89 & 79.7 & 6.1 & 3.82 \\
\hline $\begin{array}{l}\text { Took off at least one semester or } \\
\text { term }\end{array}$ & 56.4 & $\dagger$ & $\dagger$ & 73.6 & $\dagger$ & $\dagger$ \\
\hline \multicolumn{7}{|l|}{ Enrollment intensity } \\
\hline Exclusively full-time & $72.2 *$ & $20.7 *$ & 3.89 & $82.9 *$ & $13.4 *$ & 3.82 \\
\hline Mix of full-time and part-time & 57.6 & 6.1 & 10.70 & 85.5 & 16.0 & 10.80 \\
\hline Exclusively part-time & 51.5 & $\dagger$ & $\dagger$ & 69.5 & $\dagger$ & $\dagger$ \\
\hline \multicolumn{7}{|c|}{ Major for highest graduate enrollment } \\
\hline Social and behavioral sciences & 54.5 & 4.5 & 8.56 & 77.2 & 9.4 & 8.77 \\
\hline Life and physical sciences & 62.3 & 12.3 & 10.11 & 69.9 & 2.1 & 10.12 \\
\hline $\begin{array}{l}\text { Engineering, mathematics, } \\
\text { computer science }\end{array}$ & 55.5 & 5.5 & 8.75 & 68.8 & 1.0 & 9.00 \\
\hline Education & $64.6 *$ & $14.6 *$ & 7.00 & 79.6 & 11.8 & 7.20 \\
\hline Business and management & 63.1 & 13.1 & 7.20 & 78.6 & 10.8 & 7.20 \\
\hline Medicine/health & 63.2 & 13.2 & 8.17 & 77.6 & 9.8 & 8.32 \\
\hline Law & $75.7 *$ & $25.7 *$ & 10.50 & 80.9 & 13.1 & 10.57 \\
\hline Other & 60.0 & 10.0 & 7.97 & 75.6 & 7.8 & 8.10 \\
\hline Arts and humanities & 50.0 & $\dagger$ & $\dagger$ & 67.8 & $\dagger$ & $\dagger$ \\
\hline \multicolumn{7}{|l|}{$\begin{array}{l}\text { Ever received grants, employer } \\
\text { assistance, tuition waiver }\end{array}$} \\
\hline Yes & $67.2 *$ & $9.6 *$ & 3.50 & $83.7 *$ & $12.8 *$ & 3.60 \\
\hline No & 57.6 & $\dagger$ & $\dagger$ & 70.9 & $\dagger$ & $\dagger$ \\
\hline \multicolumn{7}{|l|}{$\begin{array}{l}\dagger \text { Not applicable for the reference group. } \\
* p<.05 \text {. }\end{array}$} \\
\hline \multicolumn{7}{|c|}{${ }^{1}$ The estimates are from 1993/03 Baccalaureate and Beyond Longitudinal Study (B\&B:93/03) Data Analysis System. } \\
\hline \multicolumn{7}{|c|}{${ }^{2}$ Least squares coefficients, multiplied by 100 to reflect percentages (see appendix B). } \\
\hline \multicolumn{7}{|c|}{${ }^{3}$ Standard error of least squares coefficient, adjusted for design effect, multiplied by 100 to reflect percentages (see appendix B). } \\
\hline \multicolumn{7}{|c|}{$\begin{array}{l}{ }^{4} \text { Black includes African American, Pacific Islander includes Native Hawaiian, and Hispanic includes Latino. Included in the totals but } \\
\text { not shown separately are data for those who identified themselves with another race not shown. Race categories exclude Hispanic origin } \\
\text { unless specified. } \\
\text { NOTE: The italicized group in each category is the reference group being compared. Estimates include students from the } 50 \text { states, DC, } \\
\text { and Puerto Rico. } \\
\text { SOURCE: U.S. Department of Education, National Center for Education Statistics, 1993/03 Baccalaureate and Beyond Longitudinal } \\
\text { Study (B\&B:93/03). }\end{array}$} \\
\hline
\end{tabular}


completion was no longer significant after controlling for all other independent variables. Students' age was the only exception: bivariate analysis revealed that students ages 23-24 were less likely than students age 22 or younger to have attained a graduate degree. This relationship partially remained after controlling for many other variables: students ages 23-24 were still less likely than students age 22 or younger to have earned a graduate degree.

After controlling for all other variables, several graduate enrollment characteristics, such as entry time, enrollment intensity and continuity, and graduate degree program, retained a significant relationship with graduate degree completion. Regardless of all other characteristics, full-time students were more likely than part-time students to have earned a graduate degree by 2003. Students who entered a graduate program immediately after completing a bachelor's degree had a higher rate of graduate degree completion than those who waited more than 5 years to enroll. Completion rates were also higher among students who enrolled continuously than among those who took time off, as well as among those in multiple degree programs than among those in a single degree program. Regardless of the demographic, academic, and enrollment characteristics included in this analysis, students enrolled in master's degree programs were more likely than students enrolled in doctoral degree programs to earn a graduate degree. Finally, completion rates were higher among students who had received grants, employer assistance, or a tuition waiver after controlling for various factors.

\section{Persistence}

In addition to showing students' rate of graduate degree completion, table 22 presents the results of the analysis for their rate of persistence (a concept defined as "either attaining a graduate degree or being still enrolled in a graduate program"). As with degree completion, after controlling for all other variables, many demographic and academic characteristics were no longer significantly related to persistence. However, enrollment characteristics continued to play an important role: regardless of all other characteristics, students who entered a graduate program immediately after completing a bachelor's degree, attended full time, enrolled in multiple programs, and had received grants, employer assistance, or a tuition waiver had higher persistence rates than their counterparts who waited more than 5 years to enroll, attended part time and took time off, enrolled in a single program, and had never received any financial help in terms of grants, employer assistance, and a tuition waiver.

Although doctoral degree students had a lower completion rate than master's degree students, both groups had similar persistence rates after controlling for other characteristics. This may be due to the fact that doctoral students typically take more time to finish a degree (table 
20a) and therefore have a higher rate of being still enrolled than students in master's degree programs (table 12). 


\section{Summary and Conclusions}

By 2003, some 40 percent of 1992-93 bachelor's degree recipients had enrolled in a graduate or first-professional degree program (30 percent enrolled in a single program, and 10 percent enrolled in more than one program). Of those who continued, the highest level of graduate enrollment for 76 percent of graduates was a master's degree program, for 13 percent, it was a first-professional degree program, and for 11 percent, it was a doctoral degree program. Graduate enrollment was related to a number of demographic and academic characteristics, such as students' race/ethnicity, age, and undergraduate major and GPA and parents' education. Many of these characteristics retained a significant relationship with graduate enrollment after controlling for other variables.

Graduates waited an average of 2 to 3 years from the time they completed a bachelor's degree to the time they first enrolled in a graduate or first-professional degree program. Students entering MBA programs typically waited the longest to enroll in graduate school (about 4 years) and doctoral degree students typically waited the shortest amount of time (about 1 year).

Among 1992-93 bachelor's degree recipients who had enrolled in a graduate degree program between 1993 and 2003, some 62 percent had earned at least one graduate degree by 2003. Looking at the highest degree earned, 47 percent had earned a master's degree, 10 percent a first-professional degree, and 5 percent a doctoral degree. These attainment rates could increase in the future, as about 15 percent of bachelor's degree recipients were still enrolled in a graduate degree program in 2003. About one-fourth of students who enrolled in graduate school had left without completing a graduate degree by 2003. Attainment was higher among students who enrolled in first-professional programs than among master's or doctoral students: 71 percent of students who enrolled in a first-professional degree program had earned a first-professional degree by 2003, compared with 60 percent of master's degree students and 43 percent of doctoral degree students who earned degrees in their respective programs.

The amount of time it took students to complete a graduate degree depended on the type of program in which they had enrolled. Among students who had completed a graduate degree by 2003, master's students took an average of 3 years to complete a degree, first-professional students took about 4 years, and doctoral students took about 6 years. 
Undergraduate education experiences mattered for graduate enrollment, persistence, and attainment of a graduate degree. After controlling for related factors, several undergraduate student characteristics, such as high achievement, age at bachelor's degree completion, and undergraduate major field of study, were related to enrollment in graduate school. In addition to the importance of undergraduate experiences, graduate enrollment experiences - such as the intensity and continuity of enrollment that students exhibited in a graduate degree programwere related to students' successful attainment of a graduate degree. 


\section{References}

Aldrich, J.H., and Nelson, F.D. (1984). Linear Probability, Logit and Probit Models (Quantitative Applications in Social Sciences, Vol. 45). Beverly Hills, CA: Sage Publications, Inc.

Andrieu, S.C., and St. John, E.P. (1993). The Influence of Prices on Graduate Student Persistence. Research in Higher Education, 34(4): 399-425.

Berry, W.D., and Feldman, S. (1987). Multiple Regression in Practice (Quantitative Applications in Social Sciences, Vol. 50). Beverly Hills, CA: Sage Publications, Inc.

Bowen, W.G., and Rudenstine, N.L. (1992). In Pursuit of the PhD. Princeton, NJ: Princeton University Press.

Bradburn, E.M., Berger, R., Li, X., Peter, K., and Rooney, K. (2003). A Descriptive Summary of 1999-2000 Bachelor's Degree Recipients 1 Year Later (NCES 2003-165). U.S. Department of Education. Washington, DC: National Center for Education Statistics.

Choy, S.P. (2000). Debt Burden Four Years After College (NCES 2000-188). U.S. Department of Education. Washington, DC: National Center for Education Statistics.

Choy, S.P., and Geis, S. (1997). Early Labor Force Experiences and Debt Burden (NCES 97286). U.S. Department of Education. Washington, DC: National Center for Education Statistics.

Choy, S.P., and Li, X. (2006). Dealing With Debt: 1992-93 Bachelor's Degree Recipients 10 Years Later (NCES 2006-156). U.S. Department of Education. Washington, DC: National Center for Education Statistics.

Choy, S.P., and Moskovitz, R. (1998). Student Financing of Graduate and First-Professional Education, 1995-96 (NCES 98-083). U.S. Department of Education. Washington, DC: National Center for Education Statistics. 
Clune, M.S., Nuñez, A., and Choy, S.P. (2001). Competing Choices: Men's and Women's Paths After Earning a Bachelor's Degree (NCES 2001-154). U.S. Department of Education. Washington, DC: National Center for Education Statistics.

The College Board. (2003). Trends in College Entrance Examination Board. Washington, DC: The College Entrance Examination Board.

Ethington, C.A., and Smart, J.C. (1986). Persistence to Graduate Education. Research in Higher Education, 24(3): 287-303.

Goodman, L.A. (1976). The Relationship Between Modified and Usual Multiple-Regression Approaches to the Analysis of Dichotomous Variables. In D. Hoise (Ed.), Sociological Methodology (pp. 83-110). San Francisco: Jossey-Bass.

Green, P.J., Meyers, S.L., Giese, P., Law, J., Speizer, H.M., and Tardino, V.S. (1996). Baccalaureate and Beyond Longitudinal Study: 1993/94 First Follow-up Methodology Report (NCES 96-149). U.S. Department of Education. Washington, DC: National Center for Education Statistics.

Green, P., Meyers, S., Veldman, C., and Pedlow, S. (1999). Baccalaureate and Beyond Longitudinal Study: 1993/97 Second Follow-up Methodology Report (NCES 1999-159). U.S. Department of Education. Washington, DC: National Center for Education Statistics.

Hearn, J.C. (1987). Impacts of Undergraduate Experiences on Aspirations and Plans for Graduate and Professional Education. Research in Higher Education, 27(2): 119-141.

Heller, D. (2001). Debts and Decisions: Student Loans and Their Relationship to Graduate School and Career Choice. Retrieved July 5, 2006 from http://www.eric.ed.gov/ERICDocs/data/ericdocs2/content_storage_01/0000000b/80/25/f7/9f. pdf

Hoffer, T.B., Welch, V., Williams, K., Hess, M., Webber, K., Lisek, B., Loew, D., and GuzmanBarron, I. (2005). Doctorate Recipients From United States Universities: Summary Report 2004. Chicago: NORC at the University of Chicago. Retrieved July 18, 2006 from http://www.norc.uchicago.edu/issues/sed-2004.pdf

Knoke, D. (1975). A Comparison of Log-Linear and Regression Models for Systems of Dichotomous Variables. Sociological Methods and Research, 3. Beverly Hills, CA: Sage Publications, Inc. 
Lewis-Beck, M.S. (1980). Applied Regression: An Introduction (Quantitative Applications in Social Sciences, Vol. 22). Beverly Hills, CA: Sage Publications, Inc.

Loft, J.D., Riccobono, J.A., Whitmore, R.W., Fitzgerald, R.A., and Berkner, L.K. (1995). Methodology Report for the National Postsecondary Student Aid Study, 1992-93 (NCES 95211). U.S. Department of Education. Washington, DC: National Center for Education Statistics.

McCormick, A.C., Nuñez, A., Shah, V., and Choy, S.P. (1999). Life After College: A Descriptive Summary of 1992-93 Bachelor's Degree Recipients in 1997, With an Essay on Participation in Graduate and First-Professional Education (NCES 1999-155). U.S. Department of Education. Washington, DC: National Center for Education Statistics.

McMahon, W. (1998). Conceptual Framework for the Analysis of the Social Benefits of Lifelong Learning. Education Economics, 6(3): 309-346.

Millett, C. (2003). How Undergraduate Loan Debt Affects Application and Enrollment in Graduate or First Professional School. The Journal of Higher Education, 74(4): 386-427.

National Academy of Sciences, National Research Council. (1996). The Path to the Ph.D.: Measuring Graduate Attrition in the Sciences and Humanities. Prepared by the Ad Hoc Panel on Graduate Attrition Advisory Committee. Washington, DC: Author.

Pedhazur, E.J. (1997). Multiple Regression in Behavioral Research: Prediction and Explanation (3rd ed.). Fort Worth, TX: Harcourt Brace College Publishers.

Perna, L.W. (2004). Understanding the Decision to Enroll in Graduate School: Sex and Racial/Ethnic Group Differences. The Journal of Higher Education, 75(5): 487-527.

Price, J. (2005). Marriage and Graduate Student Outcomes. Retrieved January 17, 2006, from http://www.ilr.cornell.edu/cheri/wp/cheri_wp75.pdf.

Skinner, C.J., Holt, D. and Smith, T.M.F. (Eds.). (1989). Analysis of Complex Surveys. New York: John Wiley and Sons.

Tsapogas, J., and Cahalan, M. (1996, May). Incidence of and Factors Related to Progression to Graduate School Among Recent Science and Engineering Bachelor's Degree Recipients: Results From a National Study. Paper presented at the annual meeting of the Association of Institutional Research, Albuquerque, NM. 
U.S. Department of Education, National Center for Education Statistics. (2002). The Condition of Education 2002 (NCES 2002-025). Washington, DC: U.S. Government Printing Office.

U.S. Department of Education, National Center for Education Statistics. (2004). Digest of Education Statistics, 2003 (NCES 2005-025). Washington, DC: U.S. Government Printing Office.

U.S. Department of Education, National Center for Education Statistics. (2006). The Condition of Education 2006 (NCES 2006-071). Washington, DC: U.S. Government Printing Office.

Weiler, W.C. (1991). The Effect of Undergraduate Student Loans on the Decision to Pursue Postbaccalaureate Study. Education Evaluation and Policy and Analysis, 13(3): 212-220.

Wine, J.S., Cominole, M.B., Wheeless, S., Dudley, K., and Franklin, J. (2006). 1993/03 Baccalaureate and Beyond Longitudinal Study (B\&B:93/03) Methodology Report (NCES 2006-166). U.S. Department of Education. Washington, DC: National Center for Education Statistics.

Wright, T., and Cochrane, R. (2000). Factors Influencing Successful Submissions of PhD Theses. Studies in Higher Education, 25(2): 181-195. 


\section{Appendix A-Glossary}

This glossary describes the variables used in this report. The variables come from the NCES 1993/03 Baccalaureate and Beyond Longitudinal Study (B\&B:93/03) Data Analysis System (DAS), a software application developed by NCES to generate tables from the survey data. The B\&B:93/03 DAS includes data collected in the base year (199293) and the three follow-ups conducted in 1994, 1997, and 2003. Appendix B contains descriptions of both the DAS software and the B\&B surveys.

In the index below, the variables are organized by general topic and, within topic, listed in the order in which they appear in the tables. The glossary items are listed in alphabetical order by the variable name (displayed in capital letters to the right of the variable label).

\section{Glossary Index}

\begin{tabular}{|c|}
\hline TUDENT/INSTITUTION CHARACTERISTICS \\
\hline .......GENDER \\
\hline B2ETHNIC \\
\hline Age at bachelor's degree completion.... \\
\hline Highest education level of either parent...... PAREDUC \\
\hline Bachelor's degree-granting institution ........SECTOR_B \\
\hline Baccalaureate degree major ...................... B2BAMAJR \\
\hline Bachelor's degree GPA ….......................... NORMGPA \\
\hline Marital status at bachelor's degree..... \\
\hline 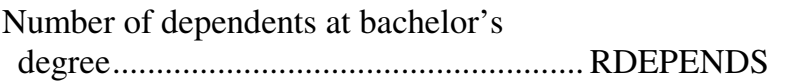 \\
\hline 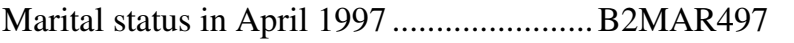 \\
\hline 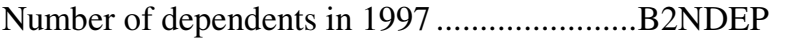 \\
\hline 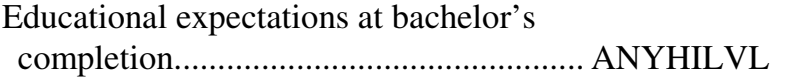 \\
\hline 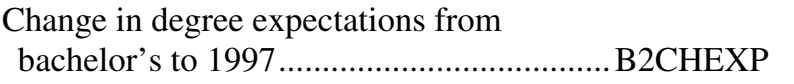 \\
\hline Educational expectations in $1997 \ldots . . .$. \\
\hline $\begin{array}{l}\text { Marital status year before graduate } \\
\text { enrollment }\end{array}$ \\
\hline $\begin{array}{l}\text { Number of dependent children year before } \\
\text { graduate enrollment..............................B3DEP1Y }\end{array}$ \\
\hline
\end{tabular}

\section{GRADUATE FINANCING}

Ever received a research assistantship ....... B3RESAST

Ever received a teaching assistantship ........B3TEAAST

Ever received tuition waiver ...................... B3TUIRED

Ever received employer assistance.............B3EMBNFT

Ever received grants, scholarships, or

fellowships .... B3GRANT

Ever received loans
Ever received grants, employer assistance, or tuition waivers.

B3GRAID

\section{EnRollment Characteristics}

Time between bachelor's completion and first graduate enrollment. B3GRDENR

Enrollment intensity. B3ENRINT

Continuity of graduate enrollment . B3ENCON

\section{ENROLLMENT AND COMPLETION OF GRADUATE EDUCATION}

Highest graduate enrollment B3HENPG2

Comprehensive graduate enrollment with multiple enrollments ..... B3GRADEN

Graduate enrollment and attainment status by 2003 B3ENRAT Major field for the highest graduate degree earned B3HDGMAJ

Highest degree attained by 2003 B3HDG03

Major for highest graduate enrollment ..... B3HENMAJ Time from first graduate enrollment to highest degree completion B3TIMGRD

\section{REASONS FOR LEAVING GRAdUATE SCHOOL}

Left graduate program because of academic problems B3GLVA

Left graduate program because of scheduling/availability B3GLVB

Left graduate program because dissatisfied with school. B3GLVC

Left graduate program because program closed. B3GLVD 
Left graduate program because done taking

Left graduate program because changed program.

Left graduate program because taking time off.

Left graduate program because enrollment not suitable

Left graduate program because job/military conflict

Left graduate program because needed to work
Left graduate program because of other B3GLVE ..B3GLVF B3GLVG . B3GLVH B3GLVI B3GLVJ financial reasons B3GLVK Left graduate program because of change in family status..... B3GLVL Left graduate program because of personal problems B3GLVM Left graduate program because of other career interests.... B3GLVN

Left graduate program to pursue other interests .................................................... B3GLV0 Left graduate program for other reason .......... B3GLVX 
DAS Variable

Indicates the highest level of education the respondent expected to complete when asked in 1993. The categories used in this report are the following:

Bachelor's degree or less

Master's degree

First-professional

Doctoral degree
Includes certificates and other formal awards, associate's degrees, and bachelor's degrees.

Includes master's degrees.

Includes first-professional degrees.

Includes doctoral degrees.

Age at bachelor's degree completion

B2AGATBA

Indicates the respondent's age at the time the bachelor's degree was received. The age categories used in this report are the following:

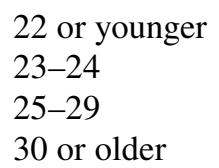

Change in degree expectations from bachelor's to 1997

B2CHEXP

Indicates whether educational expectations lowered, raised, or remained the same between two time points: the NPSAS:93 interview and the B\&B:97 follow-up.

Expectations lowered

Expectations raised

Remained the same

\section{Race/ethnicity}

\section{B2ETHNIC}

Respondents' race/ethnicity, including Hispanic/Latino. The variable gives priority to Hispanic/Latino regardless of race.

Asian/Pacific Islander

Black

Hispanic

White
A person having origins in any of the peoples of the Far East, Southeast Asia, the Indian subcontinent, or the Pacific Islands. This includes people from China, Japan, Korea, the Philippine Islands, India, Vietnam, Hawaii, and Samoa.

A person having origins in any of the black racial groups of Africa. Includes African Americans.

A person of Mexican, Puerto Rican, Cuban, Central or South American, or other Spanish culture or origin, regardless of race. Includes Latino.

A person having origins in any of the original peoples of Europe, North Africa, or the Middle East. 
DAS Variable

Educational expectations in 1997

B2HIEXP

Indicates the highest degree the respondent expected to earn when asked in the 1997 follow-up interview.

Bachelor's degree

Master's degree

First-professional degree

Doctoral degree $(\mathrm{PhD}, \mathrm{EdD}, \mathrm{DPH})$

Marital status in April 1997

B2MAR497

Indicates the respondent's marital status at the time of the 1997 follow-up interview.

Single, never been married

Married or cohabiting

Divorced/separated/widowed

Number of dependents in 1997

B2NDEP

Indicates whether the respondent reported having any dependent at the time of the 1997 follow-up interview.

Spouses are not included.

None

One or more

Baccalaureate degree major

B2BAMAJR

Identifies a respondent's undergraduate major field of study.

Business and management

Education

Engineering

Health professions

Public affairs/social services

Biological sciences

Mathematics and other sciences

Social science

History

Humanities

Psychology

Other 
DAS Variable

Indicates if a respondent had dependent children 1 year before enrolling in a graduate or first-professional degree program. This variable was derived as follows: first the date 1 year before enrolling in graduate school was determined from B3GRDST which is the earliest graduate school start date. Information from each of the follow-ups was then used to determine whether the respondent had dependent children 1 year before their first enrollment in graduate school.

No dependent children

One or more dependent children

Ever received employer assistance

B3EMBNFT

Indicates whether the student ever received assistance from an employer to pay for graduate school.

Continuity of graduate enrollment

B3ENCON

Indicates whether or not the respondent was continuously enrolled in graduate study. Does not include time taken off for summer sessions.

Continuously enrolled

Took off at least one semester/term

Graduate enrollment and attainment status by 2003

B3ENRAT

Shows the respondent's graduate degree attainment status and graduate enrollment status with the following priority: (1) Attained doctoral degree; (2) Attained first-professional degree; (3) Currently enrolled doctorate; (4) Currently enrolled first professional; (5) Attained master's degree; (6) Currently enrolled master's; (7) No attainment, previously enrolled; (8) No graduate enrollment. Respondents who have attained a master's degree are identified as having a master's degree if no higher degree was attained and the respondent is currently not enrolled in a doctoral or first-professional program.

No attainment, previously enrolled

Currently enrolled master's

Currently enrolled first-professional

Currently enrolled doctorate

Attained master's degree

Attained first-professional degree

Attained doctoral degree

No graduate enrollment 
DAS Variable

Enrollment intensity

B3ENRINT

Indicates the enrollment intensity of graduate study.

Full-time

Part-time

Mix of full-time and part-time
Student was always enrolled full time.

Student was enrolled part time at some point during graduate study.

Student had a mix of full-time and part-time enrollment throughout graduate study.

Left graduate program because of academic problems

B3GLVA

Indicates whether a respondent left graduate school because of academic problems. Applies to respondents who have enrolled in a graduate program since 1997, but were no longer enrolled and had not completed that degree by 2003. Respondents were given a list of reasons to choose from and instructed to check all that apply.

Yes

No

Left graduate program because of scheduling/availability

B3GLVB

Indicates whether a respondent left graduate school because of problems with the scheduling and availability of classes. Applies to respondents who have enrolled in a graduate program since 1997, but were no longer enrolled and had not completed that degree by 2003. Respondents were given a list of reasons to choose from and instructed to check all that apply.

Yes

No

Indicates whether a respondent left graduate school because they were dissatisfied with school. Applies to respondents who have enrolled in a graduate program since 1997, but were no longer enrolled and had not completed that degree by 2003. Respondents were given a list of reasons to choose from and instructed to check all that apply.

Yes

No

Indicates whether a respondent left graduate school because the program closed. Applies to respondents who have enrolled in a graduate program since 1997, but were no longer enrolled and had not completed that degree by 2003. Respondents were given a list of reasons to choose from and instructed to check all that apply.

Yes

No 
DAS Variable

Left graduate program because done taking class

B3GLVE

Indicates whether a respondent left graduate school because they were finished taking classes. Applies to respondents who have enrolled in a graduate program since 1997, but were no longer enrolled and had not completed that degree by 2003. Respondents were given a list of reasons to choose from and instructed to check all that apply.

$$
\begin{aligned}
& \text { Yes } \\
& \text { No }
\end{aligned}
$$

\section{Left graduate program because changed program}

B3GLVF

Indicates whether a respondent left graduate school because they changed programs. Applies to respondents who have enrolled in a graduate program since 1997, but were no longer enrolled and had not completed that degree by 2003. Respondents were given a list of reasons to choose from and instructed to check all that apply.

$$
\text { Yes }
$$

No

Indicates whether a respondent left graduate school to take time off. Applies to respondents who have enrolled in a graduate program since 1997, but were no longer enrolled and had not completed that degree by 2003 . Respondents were given a list of reasons to choose from and instructed to check all that apply.

$$
\text { Yes }
$$$$
\text { No }
$$

Indicates whether a respondent left graduate school because enrollment was not suitable to their lifestyle. Applies to respondents who have enrolled in a graduate program since 1997, but were no longer enrolled and had not completed that degree by 2003. Respondents were given a list of reasons to choose from and instructed to check all that apply.

$$
\begin{aligned}
& \text { Yes } \\
& \text { No }
\end{aligned}
$$

Indicates whether a respondent left graduate school because of job/military conflicts. Applies to respondents who have enrolled in a graduate program since 1997, but were no longer enrolled and had not completed that degree by 2003. Respondents were given a list of reasons to choose from and instructed to check all that apply.

Yes

No 
DAS Variable

Left graduate program because needed to work

B3GLVJ

Indicates whether a respondent left graduate school because they needed to work. Applies to respondents who have enrolled in a graduate program since 1997, but were no longer enrolled and had not completed that degree by 2003. Respondents were given a list of reasons to choose from and instructed to check all that apply.

$$
\text { Yes }
$$

No

Left graduate program because of other financial reasons

B3GLVK

Indicates whether a respondent left graduate school because of financial reasons. Applies to respondents who have enrolled in a graduate program since 1997, but were no longer enrolled and had not completed that degree by 2003. Respondents were given a list of reasons to choose from and instructed to check all that apply.

$$
\text { Yes }
$$

No

Left graduate program because of change in family status

B3GLVL

Indicates whether a respondent left graduate school because of a change in family status. Applies to respondents who have enrolled in a graduate program since 1997, but were no longer enrolled and had not completed that degree by 2003. Respondents were given a list of reasons to choose from and instructed to check all that apply.

Yes

No

Left graduate program because of personal problems

B3GLVM

Indicates whether a respondent left graduate school because of personal problems. Applies to respondents who have enrolled in a graduate program since 1997, but were no longer enrolled and had not completed that degree by 2003. Respondents were given a list of reasons to choose from and instructed to check all that apply.

Yes

No

Left graduate program because of other career interests

B3GLVN

Indicates whether a respondent left graduate school because of other career interests. Applies to respondents who have enrolled in a graduate program since 1997, but were no longer enrolled and had not completed that degree by 2003. Respondents were given a list of reasons to choose from and instructed to check all that apply.

Yes

No 
DAS Variable

Indicates whether a respondent left graduate school to pursue other interests. Applies to respondents who have enrolled in a graduate program since 1997, but were no longer enrolled and had not completed that degree by 2003. Respondents were given a list of reasons to choose from and instructed to check all that apply.

$$
\begin{aligned}
& \text { Yes } \\
& \text { No }
\end{aligned}
$$

Indicates whether a respondent left graduate school because of other reasons. Applies to respondents who have enrolled in a graduate program since 1997, but were no longer enrolled and had not completed that degree by 2003. Respondents were given a list of reasons to choose from and instructed to check all that apply.

$$
\text { Yes }
$$

No

\section{Comprehensive graduate enrollment with multiple enrollments}

\section{B3GRADEN}

Indicates whether a respondent enrolled in a graduate or first-professional degree program and the type of degree program in which the respondent enrolled. For respondents who enrolled in a single graduate degree program, this variable indicates the type of degree program. Those who enrolled in multiple graduate degree programs are grouped into one of the following categories: Master's degree only-Student enrolled in multiple master's degree programs. Master's and doctoral degree-Student enrolled in at least one master's degree program and at least one doctoral degree program. Other-Student enrolled in a first-professional degree program and some other type of graduate degree program.

No graduate degree enrollment

Master of Business Administration (MBA)

Master of Education (MEd)

Other master's degree

First-professional degree

Doctoral degree

Multiple enrollment: More than one master's degree

Multiple enrollment: Master's and doctoral degree

Multiple enrollment: First-professional and other

Ever received grants, employer assistance, or tuition waivers

B3GRAID

Indicates whether the student ever received grants, scholarships, fellowships, employer assistance, or tuition waivers for graduate school.

Ever received grants, scholarships, or fellowships

B3GRANT

Indicates whether the student ever received grants, scholarships, or fellowships for graduate school. 
DAS Variable

Time between bachelor's completion and first graduate enrollment

B3GRDENR

Indicates the amount of time between conferment of bachelor's degree and enrollment in a graduate degree program.

Less than 1 year

1 to 3 years

3 to 5 years

5 years or more

\section{Ever received loans}

B3GRLN2

Indicates whether the student ever received loans for graduate school.

Highest degree attained by 2003

B3HDG03

Identifies the highest degree the respondent had attained as of 2003.

Master's degree

First-professional degree

Doctoral degree

Major field for the highest graduate degree earned

Indicates the respondent's major field for the highest graduate degree program the respondent completed.

Arts and humanities

Social and behavioral sciences

Life and physical sciences

Engineering, mathematics, computer science

Education

Business and management

Medicine/health

Law

Other

Indicates the major for the highest level of graduate degree program in which the respondent enrolled.

Arts and humanities

Social and behavioral sciences

Life and physical sciences

Engineering, mathematics, computer science

Education

Business and management

Medicine/health

Law

Other 
Indicates the highest graduate degree program in which the respondent has enrolled by 2003 . This variable differs from B3HENPRG by offering separate categories for MBA and MEd degrees.

No graduate enrollment

MBA

MEd

Other master's degree

First-professional

Doctoral degree

Marital status year before graduate enrollment

B3MAR1Y

Indicates marital status 1 year before graduate enrollment. If the time between the receipt of the bachelor's degree at the NPSAS institution and the date first enrolled in a graduate program is less than 1 year, then this variable indicates marital status at the time of bachelor's degree receipt (the earliest known marital status). This variable was derived as follows: First the date 1 year before enrolling in graduate school was determined from B3GRDST which is the earliest graduate school start date. Information from each of the follow-ups was then used to determine the respondent's marital status 1 year before their first enrollment in graduate school.

\section{Single}

Married/cohabit as married

Divorced/separated/widowed

\section{Ever received a research assistantship}

B3RESAST

Indicates whether the student ever received a research assistantship while enrolled in graduate school.

Ever received a teaching assistantship

B3TEAAST

Indicates whether the student ever received a teaching assistantship while enrolled in graduate school.

Time from first graduate enrollment to highest degree completion

B3TIMGRD

Indicates the total number of years between the earliest enrollment date in a graduate program to the date the respondent received their highest graduate degree. Categories used in this report are the following:

3 year or less

3 to 5 years

5 years or more

Ever received a tuition waiver

B3TUIRED

Indicates whether the student ever received a tuition waiver for graduate school. 
DAS Variable

Gender

GENDER

Respondent's gender (male or female).

Bachelor's degree GPA

NORMGPA

Normalized calculated grade point average (GPA) based on recorded grades at sample school (4.0 scale). The categories used for this report are the following:

Under 2.5

$2.5-2.99$

$3.0-3.49$

3.5 or above

Highest education level of either parent

PAREDUC

Response to the question: "What is the highest grade or level of education completed by either of your parents?" The variable identifies 14 mutually exclusive categories that were aggregated into five groups for this report:

Less than high school

High school or less

Some postsecondary education

Bachelor's degree

Graduate degree
Less than high school

GED or high school graduation

Vocational/technical training (less than 1 year, 1 year but less than 2 year, 2 or more years); less than 2 years of college; associate's degree; 2 or more years of college

Bachelor's degree

Master's degree or equivalent; first-professional degree; other graduate professional degree; e.g., doctorate (Ph.D., Ed.D.)

Number of dependents at bachelor's degree

RDEPENDS

Indicates whether the respondent had any dependent children at the time of the NPSAS interview in 1993.

None

One or more

Marital status at bachelor's degree

RMARITST

Indicates the respondent's marital status at the time of the NPSAS interview in 1993.

Single, never married

Married or cohabiting

Divorced/separated/widowed 
DAS Variable

\section{Bachelor's degree-granting institution}

SECTOR_B

Type of institution (level and control) granting the bachelor's degree. This variable differentiates between nondoctorate-granting and doctorate-granting 4-year institutions. Non-doctorate-granting institutions include colleges with a major emphasis on baccalaureate programs and also colleges and universities that offer both baccalaureate programs and graduate education through the master's degree. Doctorate-granting institutions offer baccalaureate programs and graduate education through the doctoral degree. Institutions that offer first-professional degrees are considered doctorate-granting institutions. The categories used in this report are the following:

Public 4-year non-doctorate-granting

Public 4-year doctorate-granting

Private not-for-profit 4-year non-doctorate-granting

Private not-for-profit 4-year doctorate-granting

Other 


\section{THIS PAGE INTENTIONALLY LEFT BLANK}




\section{Appendix B-Technical Notes and Methodology}

\section{The 1993/03 Baccalaureate and Beyond Longitudinal Study}

The estimates and statistics in the tables and figures of this report are based on data from the first, second, and third follow-ups of the 1993/03 Baccalaureate and Beyond Longitudinal Study (B\&B:93/03). This study tracks the experiences of a cohort of college graduates who received a baccalaureate degree during the 1992-93 academic year and were first interviewed as part of the 1992-93 National Postsecondary Student Aid Study (NPSAS:93), conducted by the U.S. Department of Education's National Center for Education Statistics (NCES). NPSAS is based on a nationally representative sample of all students in postsecondary education institutions, including undergraduate, graduate, and first-professional students. For NPSAS:93, information was obtained from about 1,100 postsecondary institutions on approximately 53,000 undergraduates and about 13,000 graduate and first-professional students who were enrolled at some time between July 1, 1992 and June 30, 1993.

For B\&B:93/03, those members of the NPSAS:93 sample who completed a bachelor's degree between July 1, 1992 and June 30, 1993 were identified and contacted for a 1-year followup interview in 1994. The second follow-up of the B\&B cohort occurred in 1997, approximately 4 years after graduation. The final follow-up survey, 10 years after graduation in 2003 , is the focus of this report. However, the estimates in this report are based on the approximately 8,100 bachelor's degree recipients who participated in all four surveys - the NPSAS base-year survey and the three follow-ups_representing about 1.2 million bachelor's degree recipients (U.S. Department of Education 2002, table 247).

The NPSAS:93 sample, while representative and statistically accurate, was not a simple random sample. Instead, the survey sample was selected using a more complex three-step procedure with stratified samples and differential probabilities of selection at each level. Postsecondary institutions were initially selected within geographic strata. Once institutions were organized by ZIP Code and state, they were further stratified by control (i.e., public; private notfor-profit; or private for-profit) and degree offering (less-than-2-year, 2- to 3-year, 4-year nondoctorate-granting, and 4-year doctorate-granting). The NPSAS:93 survey sample yielded an overall weighted institutional response rate of 88 percent. For more information about the 
NPSAS:93 survey, refer to the Methodology Report for the National Postsecondary Student Aid Study, 1992-93 (Loft et al. 1995).

For the first follow-up B\&B interview in 1994, a total of about 10,100 eligible individuals completed the interview between June and December-using computer-assisted telephone interviewing (CATI), with field interviewing when necessary-which corresponds to a weighted response rate of 90 percent (from the NPSAS:93-identified B\&B eligible sample of about 11,000 cases). Data collection for the second follow-up interview of the B\&B cohort took place between April and December 1997; about 10,100 individuals completed the interview, yielding a weighted response rate of 90 percent. For more information on procedures for the first and second follow-ups, consult the respective methodology reports (Green et al. [1996] for the first follow-up and Green et al. [1999] for the second follow-up).

Between February and September 2003, the third and final follow-up of the 1992-93 cohort of bachelor's degree recipients was conducted. For the first time, students were offered the opportunity to conduct the B\&B interview via the Internet. A single web-based interview was designed and programmed for use as a self-administered interview, a telephone interview, and an in-person interview. All respondents to the 1997 interview were included for participation in the 2003 follow-up; a subsample of about one-third of nonrespondents from 1997 was also included, resulting in a final sample of about 10,400 individuals. Almost 9,000 members of this final sample responded, yielding a weighted response rate of 83 percent. For more details about the third follow-up survey procedures, consult the 1993/03 Baccalaureate and Beyond Longitudinal Study (B\&B:93/03) Methodology Report (Wine et al. 2006).

Except for having all graduated in the same academic year, the 1992-93 graduate cohort members could be as diverse as possible in other aspects (e.g., the degree recipients could have been enrolled sporadically over time or enrolled continuously; some might have delayed their entry into postsecondary education, while others might have entered college right after completing high school). Therefore, the B\&B:93/03 data provide the first opportunity to examine how a nationally representative, cross-sectional group of college graduates pursued graduate education over a period of 10 years after their graduation. The B\&B dataset contains comprehensive data on post-baccalaureate graduate enrollment, attainment, student demographic characteristics, and labor force participation and finances (including education loans).

\section{Weighting}

All estimates in this report are weighted to compensate for unequal probability of selection into the survey sample and to adjust for nonresponse. The specific weight variable used in this 
report is WTC00, which was constructed as the panel weight for analyzing those students who responded to all four surveys: NPSAS:93 and the 1994, 1997, and 2003 B\&B follow-up interviews. For more information on weighting, consult chapter 6, "Weighting and Variance Estimation," of the B\&B:93/03 methodology report (Wine et al. 2006).

\section{Overall Response Rates}

As discussed earlier in this appendix, the weighted institution response rate for NPSAS:93 was 88 percent. The weighted student response rate was 90 percent for both the first (in 1994) and second (in 1997) follow-up B\&B interviews and 83 percent for the final B\&B follow-up interview (in 2003).

\section{Accuracy of Estimates}

The statistics in this report are estimates derived from a sample. Two broad categories of error occur in such estimates: sampling and nonsampling errors. Sampling errors occur because observations are based only on samples of students, not entire populations. Nonsampling errors occur not only in sample surveys but also in complete censuses of entire populations. Nonsampling errors can be attributed to a number of sources: inability to obtain complete information about all students in all institutions in the sample (some students or institutions refused to participate, or students participated but answered only certain items); ambiguous definitions; differences in interpreting questions; inability or unwillingness to give correct information; mistakes in recording or coding data; and other errors of collecting, processing, sampling, and imputing missing data. Readers interested in efforts to minimize nonsampling errors for estimates used in this report should consult the methodology reports referenced earlier in this appendix. Below is a discussion of possible bias in statistics for variables with low item response rates presented in the tables/figures of this report.

\section{Item Response Bias}

All the variables used in this report and defined in appendix A had item response rates above 85 percent. Therefore, a bias analysis for individual survey items was not necessary.

\section{Student-Level Nonresponse Bias Analysis}

A student respondent is defined as any sample member who is determined to be eligible for the study and has valid data for the selected set of analytical variables. As noted earlier, the unweighted student response rate was 86.3 percent, and the weighted response rate was 83.4 
percent. A nonresponse bias analysis was conducted as a part of the nonresponse adjustment for the analysis weight. The nonresponse bias was estimated for the variables known for both respondents and nonrespondents within each institution type. These variables included the following:

- Age in the base year (NPSAS:93),

- Race/ethnicity,

- Gender,

- U.S. citizenship status,

- Attendance status in the base year,

- Institution control,

- Bureau of Economic Analysis Code (OBE) Region,

- Type of institution/enrollment category,

- B\&B institution stratum,

- B\&B student stratum,

- Whether applied for aid in the base year,

- Receipt of federal aid in the base year,

- Receipt of Pell Grant in the base year,

- Receipt of Stafford Loan in the base year,

- Receipt of state aid in the base year,

- Receipt of institution aid in the base year,

- Receipt of any aid in the base year,

- Prior respondent to either 1994 or 1997 interview,

- Income in the base year (parent income for dependent students and student income for independent students),

- Number of telephone numbers available during B\&B:93/03 data collection,

- Number of times an answering machine was encountered during B\&B:93/03, and

- Whether the student was located in a field cluster for B\&B:93/03.

The steps for nonresponse bias analysis included estimating the nonresponse bias and testing (adjusting for multiple comparisons) to determine whether the bias is significant at the 5 percent level. Second, nonresponse adjustment factors were computed using a subset of variables listed above. The nonresponse adjustments were designed to significantly reduce or eliminate nonresponse bias for variables included in the corresponding models. Third, after the weights were computed, any remaining bias was estimated for the variables listed above and statistical tests were performed to determine the significance of any remaining nonresponse bias.

The weighting adjustments reduced, and in some cases eliminated, bias for students. Prior to the nonresponse weighting adjustment, the response bias was statistically significantly different from zero for 21 percent of the variables; the mean of the absolute values of the biases was 0.40 and the median was 0.20 . After the nonresponse weighting adjustment, none of the 
biases were significantly different from zero; the mean of the absolute values of the biases was 0.01 and median was 0.002 .

\section{Data Analysis System}

The estimates presented in this report were produced using the B\&B:93/03 Data Analysis System (DAS). (The data from the 1994, 1997, and 2003 interviews were incorporated into one DAS.) The DAS software makes it possible for users to specify and generate their own tables. The DAS also contains a detailed description of how each variable was created and includes question wording for items coming directly from an interview.

With the DAS, users can replicate or expand upon the tables presented in this report. In addition to the table estimates, the DAS calculates the proper standard errors ${ }^{1}$ and weighted sample sizes for these estimates. For example, table B-1 contains standard errors that correspond to estimates in table 1 in the report. If the number of valid cases is too small to produce a reliable estimate (fewer than 30 cases), the DAS prints the message "low-N" instead of the estimate. All standard errors for estimates presented in this report can be viewed at http://nces.ed.gov/das/library/reports.asp. In addition to tables, the DAS will also produce a correlation matrix of selected variables to be used for linear regression models. Included in the output with the correlation matrix are the design effects (DEFTs) for each variable in the matrix. Because statistical procedures generally compute regression coefficients based on simple random sample assumptions, the standard errors must be adjusted with the design effects to take into account the stratified sampling method used in the NPSAS surveys.

The DAS can be accessed electronically at http://nces.ed.gov/das. For more information about the Data Analysis System, contact:

Aurora D'Amico

Postsecondary Studies Division

National Center for Education Statistics

1990 K Street NW

Washington, DC 20006-5652

(202) 502-7334

aurora.d'amico@ed.gov

\footnotetext{
1 The B\&B samples are not simple random samples, and therefore, simple random sample techniques for estimating sampling error cannot be applied to these data. The DAS takes into account the complexity of the sampling procedures and calculates standard errors appropriate for such samples. The method for computing sampling errors used by the DAS involves approximating the estimator by balanced repeated replication of the sampled population. The procedure is typically referred to as the "balanced repeated replication technique" (BRR).
} 
Table B-1. Standard errors for table 1: Percentage distribution of 1992-93 bachelor's degree recipients' highest graduate enrollment, by student and institution characteristics: 2003

\begin{tabular}{|c|c|c|c|c|c|c|c|}
\hline \multirow[b]{2}{*}{$\begin{array}{l}\text { Student and institution } \\
\text { characteristics }\end{array}$} & \multirow[b]{2}{*}{$\begin{array}{r}\text { No } \\
\text { enroll- } \\
\text { ment } \\
\end{array}$} & \multicolumn{6}{|c|}{ Highest graduate enrollment } \\
\hline & & $\begin{array}{r}\text { Total } \\
\text { any } \\
\text { enroll- } \\
\text { ment } \\
\end{array}$ & MBA & MEd & $\begin{array}{r}\text { Other } \\
\text { master's }\end{array}$ & $\begin{array}{r}\text { First- } \\
\text { profes- } \\
\text { sional } \\
\end{array}$ & Doctora \\
\hline Total & 0.80 & 0.80 & 0.39 & 0.41 & 0.56 & 0.32 & 0.27 \\
\hline \multicolumn{8}{|l|}{ Gender } \\
\hline Male & 0.99 & 0.99 & 0.56 & 0.42 & 0.81 & 0.57 & 0.50 \\
\hline Female & 1.21 & 1.21 & 0.57 & 0.63 & 0.65 & 0.35 & 0.39 \\
\hline \multicolumn{8}{|l|}{ Race/ethnicity } \\
\hline White & 0.80 & 0.80 & 0.37 & 0.44 & 0.58 & 0.32 & 0.31 \\
\hline Black & 3.05 & 3.05 & 2.14 & 1.56 & 2.45 & 1.19 & 1.66 \\
\hline Hispanic & 3.92 & 3.92 & 2.51 & 1.82 & 2.41 & 1.36 & 1.36 \\
\hline Asian/Pacific Islander & 4.58 & 4.58 & 1.83 & 1.53 & 2.60 & 2.35 & 1.03 \\
\hline \multicolumn{8}{|c|}{ Age at bachelor's degree completion } \\
\hline 22 or younger & 1.07 & 1.07 & 0.45 & 0.63 & 0.85 & 0.44 & 0.57 \\
\hline $23-24$ & 1.20 & 1.20 & 0.68 & 0.86 & 0.85 & 0.42 & 0.39 \\
\hline $25-29$ & 1.98 & 1.98 & 1.26 & 0.88 & 1.35 & 0.66 & 0.44 \\
\hline 30 or older & 2.36 & 2.36 & 1.46 & 1.25 & 1.34 & 0.62 & 0.59 \\
\hline \multicolumn{8}{|c|}{ Highest education level by either parent } \\
\hline Less than high school & 3.65 & 3.65 & 2.25 & 1.81 & 2.11 & 0.82 & 1.07 \\
\hline High school or equivalency & 1.40 & 1.40 & 0.81 & 0.79 & 0.96 & 0.52 & 0.39 \\
\hline Some postsecondary & 1.72 & 1.72 & 1.00 & 0.84 & 1.24 & 0.83 & 0.59 \\
\hline Bachelor's degree & 1.39 & 1.39 & 0.70 & 0.79 & 0.82 & 0.73 & 0.62 \\
\hline Advanced degree & 1.36 & 1.36 & 0.94 & 0.77 & 0.99 & 0.64 & 0.74 \\
\hline \multicolumn{8}{|c|}{$\begin{array}{l}\text { Bachelor's degree-granting institution } \\
\text { Public 4-year }\end{array}$} \\
\hline Non-doctoral-granting & 1.43 & 1.43 & 0.78 & 1.00 & 0.95 & 0.44 & 0.39 \\
\hline Doctoral-granting & 1.24 & 1.24 & 0.55 & 0.51 & 0.66 & 0.35 & 0.51 \\
\hline \multicolumn{8}{|l|}{ Private not-for-profit 4-year } \\
\hline Non-doctoral-granting & 2.17 & 2.17 & 1.03 & 0.73 & 1.09 & 0.74 & 0.61 \\
\hline Doctoral-granting & 2.28 & 2.28 & 1.36 & 0.87 & 1.52 & 1.25 & 0.99 \\
\hline Other & 5.94 & 5.94 & 5.50 & 1.21 & 4.21 & 1.37 & 0.94 \\
\hline
\end{tabular}

See notes at end of table. 
Table B-1. Standard errors for table 1: Percentage distribution of 1992-93 bachelor's degree recipients' highest graduate enrollment, by student and institution characteristics: 2003—Continued

\begin{tabular}{|c|c|c|c|c|c|c|c|}
\hline \multirow[b]{2}{*}{$\begin{array}{l}\text { Student and institution } \\
\text { characteristics }\end{array}$} & \multirow[b]{2}{*}{$\begin{array}{r}\text { No } \\
\text { enroll- } \\
\text { ment } \\
\end{array}$} & \multicolumn{6}{|c|}{ Highest graduate enrollment } \\
\hline & & $\begin{array}{r}\text { Total } \\
\text { any } \\
\text { enroll- } \\
\text { ment } \\
\end{array}$ & MBA & MEd & $\begin{array}{r}\text { Other } \\
\text { master's } \\
\end{array}$ & $\begin{array}{r}\text { First- } \\
\text { profes- } \\
\text { sional } \\
\end{array}$ & Doctoral \\
\hline \multicolumn{8}{|l|}{ Baccalaureate degree major } \\
\hline Arts and humanities & 2.03 & 2.03 & 0.66 & 0.93 & 1.34 & 0.62 & 0.52 \\
\hline Social and behavioral sciences & 1.96 & 1.96 & 1.11 & 0.78 & 1.37 & 0.88 & 0.82 \\
\hline Life and physical sciences & 3.16 & 3.16 & 0.90 & 0.64 & 1.47 & 2.25 & 1.68 \\
\hline $\begin{array}{l}\text { Engineering, mathematics, } \\
\text { computer science }\end{array}$ & 1.91 & 1.91 & 1.09 & 0.90 & 1.84 & 0.64 & 1.16 \\
\hline Education & 1.70 & 1.70 & 0.48 & 1.60 & 1.06 & 0.41 & 0.62 \\
\hline Business and management & 1.56 & 1.56 & 1.27 & 0.50 & 0.98 & 0.47 & 0.25 \\
\hline Medicine/health & 2.61 & 2.61 & 1.14 & 0.78 & 2.27 & 1.09 & 0.33 \\
\hline Law & 14.14 & 14.14 & 4.48 & 3.92 & 2.19 & 13.18 & $\dagger$ \\
\hline Other & 4.30 & 4.30 & 1.20 & 2.16 & 2.49 & 1.19 & 1.03 \\
\hline \multicolumn{8}{|l|}{ Bachelor's degree GPA } \\
\hline Under 2.5 & 1.32 & 1.32 & 0.84 & 1.11 & 0.94 & 0.37 & 0.37 \\
\hline $2.5-2.99$ & 1.21 & 1.21 & 0.76 & 0.72 & 0.82 & 0.60 & 0.38 \\
\hline $3.0-3.49$ & 1.42 & 1.42 & 0.77 & 0.68 & 0.78 & 0.44 & 0.56 \\
\hline 3.5 or above & 1.94 & 1.94 & 0.89 & 0.74 & 1.34 & 0.84 & 0.65 \\
\hline \multicolumn{8}{|l|}{ Undergraduate debt } \\
\hline Did not borrow & 1.00 & 1.00 & 0.56 & 0.45 & 0.77 & 0.32 & 0.39 \\
\hline$\$ 1-4,999$ & 2.29 & 2.29 & 1.30 & 0.94 & 1.19 & 0.76 & 0.72 \\
\hline$\$ 5,000-9,999$ & 2.58 & 2.58 & 1.33 & 1.07 & 1.53 & 0.80 & 0.48 \\
\hline$\$ 10,000-14,999$ & 1.69 & 1.69 & 1.19 & 1.12 & 1.30 & 1.06 & 0.74 \\
\hline$\$ 15,000$ or more & 2.32 & 2.32 & 1.12 & 1.13 & 1.94 & 0.87 & 1.13 \\
\hline
\end{tabular}

$\dagger$ Not applicable.

SOURCE: U.S. Department of Education, National Center for Education Statistics, 1993/03 Baccalaureate and Beyond Longitudinal Study (B\&B:93/03).

\section{Statistical Procedures}

\section{Differences Between Means}

The descriptive comparisons in this report were tested using Student's $t$ statistic.

Differences between estimates are tested against the probability of a Type I error ${ }^{2}$ or significance level. The significance levels were determined by calculating the Student's $t$ values for the

\footnotetext{
2 A Type I error occurs when one concludes that a difference observed in a sample reflects a true difference in the population from which the sample was drawn, when no such difference is present.
} 
differences between each pair of means or proportions and comparing these with published tables of significance levels for two-tailed hypothesis testing $(p<.05)$.

Student's $t$ values may be computed to test the difference between estimates with the following formula:

$$
t=\frac{E_{1}-E_{2}}{\sqrt{s e_{1}^{2}+s e_{2}^{2}}}
$$

where $E_{1}$ and $E_{2}$ are the estimates to be compared and $s e_{1}$ and $s e_{2}$ are their corresponding standard errors. This formula is valid only for independent estimates. When estimates are not independent, a covariance term must be added to the formula:

$$
t=\frac{E_{1}-E_{2}}{\sqrt{s e_{1}^{2}+s e_{2}^{2}-2(r) s e_{1} s e_{2}}}
$$

where $r$ is the correlation between the two estimates. ${ }^{3}$ This formula is used when comparing two percentages from a distribution that adds to 100. If the comparison is between the mean of a subgroup and the mean of the total group, the following formula is used:

$$
t=\frac{E_{s u b}-E_{t o t}}{\sqrt{s e_{s u b}^{2}+s e_{t o t}^{2}-2 p s e_{s u b}^{2}}}
$$

where $p$ is the proportion of the total group contained in the subgroup. ${ }^{4}$ The estimates, standard errors, and correlations can all be obtained from the DAS.

There are some hazards in using statistical tests for each comparison. First, comparisons based on large $t$ statistics may appear to merit special attention. This can be misleading since the magnitude of the $t$ statistic is related not only to the observed differences in means or percentages, but also to the number of respondents in the specific categories used for comparison. Hence, a small difference compared across a large number of respondents would produce a large $t$ statistic.

A second hazard in using statistical tests is the possibility of a "false positive" or Type I error. In the case of a $t$ statistic, this false positive would result when a difference measured with a particular sample showed a statistically significant difference when there is no difference in the underlying population. Statistical tests are designed to control for this type of error, denoted by

${ }^{3}$ U.S. Department of Education, National Center for Education Statistics, A Note from the Chief Statistician, no. $2,1993$.

${ }^{4}$ Ibid. 
alpha. The alpha level of .05 selected for findings in this report indicates that a difference of a certain magnitude or larger would be produced no more than one time out of 20 when there was no actual difference in the quantities in the underlying population. When researchers test hypotheses that show $t$ values below the .05 significance level, they treat this finding as rejecting the null hypothesis that there is no difference between the two quantities. Failing to reject the null hypothesis (i.e., finding no difference), however, does not necessarily imply that the values are the same or equivalent.

\section{Linear Trends}

While many descriptive comparisons in this report were tested using Student's $t$ statistic, some comparisons among categories of an ordered variable with three or more levels involved a test for a linear trend across all categories (in particular, for parents' education and GPA), rather than a series of tests between pairs of categories. In this report, when differences among percentages were examined relative to a variable with ordered categories, Analysis of Variance (ANOVA) was used to test for a linear relationship between the two variables. To do this, ANOVA models included orthogonal linear contrasts corresponding to successive levels of the independent variable. The squares of the balanced repeated replication standard errors (i.e., standard errors that were calculated by the balanced repeated replication method), the variance between the means, and the unweighted sample sizes were used to partition total sum of squares into within- and between-group sums of squares. These were used to create mean squares for the within- and between-group variance components and their corresponding $F$ statistics, which were then compared with published values of $F$ for a significance level of .05 .5 Significant values of both the overall $F$ and the $F$ associated with the linear contrast term were required as evidence of a linear relationship between the two variables. Means and balanced repeated replication (BRR) standard errors were calculated by the DAS. Unweighted sample sizes are not available from the DAS and were provided by NCES.

\section{Multivariate Commonality Analysis}

There are many ways for members of the public and other researchers to make use of NCES results. The most popular way is to read the written reports. Other ways include obtaining and analyzing public use and restricted use data files, which allow researchers to carry out and publish their own secondary analyses of NCES data.

\footnotetext{
5 More information about ANOVA and significance testing using the $F$ statistic can be found in any standard textbook on statistical methods in the social and behavioral sciences.
} 
It is very important when reading NCES reports to remember that they are descriptive in nature. That is, they are limited to describing some aspect of the condition of education. These results are usefully viewed as suggesting various ideas to be examined further in light of other data, including state and local data, and in the context of the extensive research literature elaborating on the many factors predicting and contributing to educational achievement or to other outcome variables of interest.

However, some readers are tempted to make unwarranted causal inferences from simple cross tabulations. It is never the case that a simple cross tabulation of any variable with a measure of educational achievement is conclusive proof that differences in that variable are a cause of differential educational achievement or that differences in that variable explain any other outcome variable. The old adage that "correlation is not causation" is a wise precaution to keep in mind when considering the results of NCES reports. Experienced researchers are aware of the design limitations of many NCES data collections. They routinely formulate multiple hypotheses that take these limitations into account, and readers of this volume are encouraged to do likewise. As part of the Institute of Education Sciences, NCES has a responsibility to try to discourage misleading inferences from the data presented and to educate the public on the genuine difficulty of making valid causal inferences in a field as complex as education. Our reports are carefully worded to achieve this end.

This focus on description, eschewing causal analysis, extends to multivariate analyses as well as bivariate ones. Some NCES reports go beyond presenting simple cross tabulations and present results from multiple regression equations that include many different independent ("predictor") variables. This can be useful to readers, especially those without the time or training to access the data themselves. Because many of the independent variables included in descriptive reports are related to each other and to the outcome they are predicting, a multivariate approach can help users to understand their interrelation. For example, students' gender and undergraduate major are associated with each other and are both predictors of enrollment in graduate school. What happens to the relationship between students' gender and enrollment in graduate school when undergraduate major differences are accounted for? Such a question cannot be answered using bivariate techniques alone.

One way to answer the question is to create three variable tabulations, a method sometimes used in NCES reports. When the number of independent variables increases to four or more, however, the number of cases in individual cells of such a table often becomes too small to find significant differences simply because there are too few cases to achieve statistical significance. To make economical use of the many available independent variables in the same data display, 
other statistical methods must be used that can take multiple independent variables into account simultaneously.

Multiple linear regression is often used for this purpose: to adjust for the common variation among a list of independent variables. This approach is sometimes referred to as "commonality analysis,"6 because it identifies lingering relationships after adjustment for "common" variation. This method is used simply to confirm statistically significant associations observed in the bivariate analysis, while taking into account the interrelationship of the independent variables.

Thus, this multiple regression approach is descriptive. Significant coefficients reported in the regression tables indicate that when the variable is deleted from (or added to) the set of independent variables, it results in a non-zero change in R-squared, which is the basis of the commonality analysis. In other words, a significant coefficient means that the independent variable has a relationship with the outcome variable that is unique, or distinct from its relationship with other independent variables in the model.

Multivariate description of this sort is distinct from both a modeling approach in which an analyst attempts to identify the smallest relevant set of causal or explanatory independent variables associated with the dependent variable or variables and an approach using one of the many varieties of structural equation modeling. In contrast, a multivariate descriptive or commonality approach provides a richer understanding of the data without needing to make any kind of causal assumptions, which is why descriptive multivariate commonality analysis is often used in NCES statistical reports. The commonality analyses discussed in this report use the Weighted Least Squares (WLS) estimation method. WLS regression weights cases differentially. The size of the weight indicates the precision of the information contained in the associated observation. The weights determine the contribution of each observation to the final parameter estimates and standard errors.

When should commonality analysis be employed? It should be used in statistical analysis reports when independent variables are correlated with both the outcome variable and with each other. This will allow the analyst to determine how much of the effect of one independent variable is due to the influence of other independent variables, because in a multiple regression procedure these effects are adjusted for. For example, because the strength of the statistical relationship between students' gender and enrollment in graduate school may be affected by undergraduate major, computing a multiple regression equation that contains both variables allows the analyst to determine how much, if any, difference in graduate enrollment between men and women is due to differences in undergraduate major.

\footnotetext{
${ }^{6}$ For more information about commonality analysis, see Pedhazur (1997).
} 
As discussed in the Data Analysis System section above, all analyses included in PEDAR reports must be based on the DAS, which is available to the public online (http://www.nces.ed.gov/DAS). Exclusively using the DAS in this way provides readers direct access to the findings and methods used in the report so that they may replicate or expand on the estimates presented. However, the DAS does not allow users access to the raw data, which limits the range of covariation procedures that can be used. Specifically, the DAS produces correlation matrices, which can be used as input in standard statistical packages to produce least squares regression models. This means that logit or probit procedures, more appropriate for dichotomous dependent variables, cannot be used. ${ }^{7}$ However, empirical studies have shown that when the mean value of a dichotomous dependent variable falls between .25 and .75 (as it does in this analysis), regression and log-linear models are likely to produce similar results. ${ }^{8}$

The independent variables analyzed in this study and subsequently included in the multivariate model were chosen based largely on earlier empirical studies (cited in the text), which showed significant associations with the key analytic variable, graduate enrollment, persistence, and attainment. Before conducting the study, a detailed analysis plan was reviewed by a Technical Review Panel (TRP) of experts in the field of higher education research, and additional independent variables requested by the TRP were considered for inclusion. The analysis plan listed all independent variables to be included in the study. The TRP also reviewed the preliminary results, as well as the first draft of this report. The analysis plan and subsequent report were modified based on TRP comments.

\section{Missing Data and Adjusting for Complex Sample Design}

The DAS computes the correlation matrix using pairwise missing values. In regression analysis, there are several common approaches to the problem of missing data. The two simplest approaches are pairwise deletion of missing data and listwise deletion of missing data. In pairwise deletion, each correlation is calculated using all of the cases for the two relevant variables. For example, suppose you have a regression analysis that uses variables X1, X2, and $\mathrm{X} 3$. The regression is based on the correlation matrix between $\mathrm{X} 1, \mathrm{X} 2$, and $\mathrm{X} 3$. In pairwise deletion, the correlation between $\mathrm{X} 1$ and $\mathrm{X} 2$ is based on the nonmissing cases for $\mathrm{X} 1$ and $\mathrm{X} 2$. Cases missing on either X1 or X2 would be excluded from the calculation of the correlation. In listwise deletion, the correlation between $\mathrm{X} 1$ and $\mathrm{X} 2$ would be based on the nonmissing values for $\mathrm{X} 1, \mathrm{X} 2$, and $\mathrm{X} 3$. That is, all of the cases with missing data on any of the three variables would be excluded from the analysis.

\footnotetext{
${ }^{7}$ See Aldrich and Nelson (1984). Analysts who wish to estimate other types of models can apply for a restricted data license from NCES.

${ }^{8}$ See, for example, Goodman (1976) and Knoke (1975).
} 
The correlation matrix produced by the DAS can be used by most statistical software packages as the input data for least squares regression. ${ }^{9}$ The DAS provides either the SPSS or SAS code necessary to run least squares regression models. The DAS also provides additional information to incorporate the complex sample design into the statistical significance tests of the parameter estimates. Most statistical software packages assume simple random sampling when computing standard errors of parameter estimates. Because of the complex sampling design used for the survey, this assumption is incorrect. A better approximation of the standard errors can be made by multiplying each standard error by the design effect associated with the dependent variable (DEFT) ${ }^{10}$ where the DEFT is the ratio of the true standard error to the standard error computed under the assumption of simple random sampling. The DEFT is calculated by the DAS and displayed with the correlation matrix output.

\section{Interpreting the Results}

The least squares regression coefficients displayed in the regression tables in this report are expressed as percentages. Significant coefficients represent the observed differences that remain between the analysis group (i.e., students whose parents had a high school education) and the comparison group (i.e., students whose parents held graduate degrees) after controlling for the relationships of all selected independent variables. For example, in table 21, the least squares coefficient for students who had master's degree aspirations when they completed a bachelor's degree is 15.1. This means that compared with students who expected their highest degree to be a bachelor's degree, roughly 15 percent more of those who expected to earn a master's degree were likely to enroll in a graduate degree program after controlling for the relationships among all other independent variables.

\footnotetext{
${ }^{9}$ For more information about least squares regression, see Lewis-Beck (1980) and Berry and Feldman (1987).

10 The adjustment procedure and its limitations are described in Skinner, Holt, and Smith (1989).
} 